\title{
Peralkaline Felsic Magmatism of the Atlantic Islands
}

\author{
Adam J. Jeffery and Ralf Gertisser* \\ School of Geography, Geology and the Environment, Keele University, Staffordshire, United Kingdom
}

The oceanic-island magmatic systems of the Atlantic Ocean exhibit significant diversity in their respective sizes, ages, and the compositional ranges of their eruptive products. Nevertheless, almost all of the Atlantic islands and island groups have produced peralkaline felsic magmas, implying that similar petrogenetic regimes may be operating throughout the Atlantic Ocean, and arguably elsewhere. The origins of peralkaline magmas are frequently linked to low-degree partial melting of enriched mantle, followed by protracted differentiation in the shallow crust. However, additional petrogenetic processes such as magma mixing, crustal melting, and contamination have been identified at numerous peralkaline centers. The onset of peralkalinity leads to magma viscosities lower than those typical for metaluminous felsic magmas, which has profound implications for processes such as crystal settling. This study represents a compilation of published and original data which demonstrates trends that suggest

OPEN ACCESS

Edited by:

Patricia Larrea,

Universidad Nacional Autónoma

de México, Mexico

Reviewed by:

Felix Genske,

University of Münster, Germany

Jakub Sliwinski,

ETH Zürich, Switzerland

Teresa Ubide,

The University of Queensland,

Australia

*Correspondence:

Ralf Gertisser

r.gertisser@keele.ac.uk

Specialty section:

This article was submitted to

Volcanology,

a section of the journal

Frontiers in Earth Science

Received: 28 February 2018 Accepted: 13 September 2018

Published: 20 November 2018

Citation:

Jeffery AJ and Gertisser R (2018)

Peralkaline Felsic Magmatism of the

Atlantic Islands.

Front. Earth Sci. 6:145.

doi: 10.3389/feart.2018.00145 that the peralkaline magmas of the Atlantic Ocean islands are generated primarily via extended (up to $\sim 95 \%$ ), open system fractional crystallization of mantle-derived mafic magmas. Crustal assimilation is likely to become more significant as the system matures and fusible material accumulates in the crust. Magma mixing may occur between various compositional end-members and may be recognized via hybridized intermediate magmas. The peralkaline magmas are hydrous, and frequently zoned in composition, temperature, and/or water content. They are typically stored in shallow crustal magma reservoirs $(\sim 2-5 \mathrm{~km})$, maintained by mafic replenishment. Low melt viscosities $\left(1 \times 10^{1.77}\right.$ to $\left.1 \times 10^{4.77} \mathrm{~Pa} \mathrm{~s}\right)$ facilitate two-phase flow, promoting the formation of alkali-feldspar crystal mush. This mush may then contribute melt to an overlying melt lens via filter pressing or partial melting. We utilize a three-stage model to account for the establishment, development, and termination of peralkaline magmatism in the ocean island magmatic systems of the Atlantic. We suggest that the overall control on peralkaline magmatism in the Atlantic is magma flux rate, which controls the stability of upper crustal magma reservoirs. The abundance of peralkaline magmas in the Atlantic suggests that their development must be a common, but not inevitable, stage in the evolution of ocean islands.

Keywords: peralkaline, ocean island, crystal mush, crystal settling, fractional crystallization

\section{INTRODUCTION}

Oceanic island volcanic centers have been instrumental in the understanding of fundamental petrological features and processes, including mantle heterogeneity, melt generation, and magma evolution in oceanic intraplate settings (e.g., Hofmann, 2003; Fitton, 2007; White, 2010). Ocean island basalts (OIBs) can be related more directly to the underlying mantle source(s) than 
continental basalts, undergoing less contamination on ascent and therefore serving as a fingerprint of mantle heterogeneity. In addition to OIBs, many oceanic island volcanic centers also exhibit a variety of magma compositions that are more felsic, extending to rhyolitic and phonolitic, with various intermediate compositions which are typically subordinate to the mafic and felsic compositions (e.g., Daly, 1925). In many cases, the felsic magmas are variably peralkaline (i.e., Peralkalinity index $(\mathrm{PI})=$ molar $\left.\left(\mathrm{Na}_{2} \mathrm{O}+\mathrm{K}_{2} \mathrm{O}\right) / \mathrm{Al}_{2} \mathrm{O}_{3}\right)$ is greater than 1), making them particularly unusual not only due to their sometimes extreme enrichment in halogens, rare earth elements (REEs), high field strength elements (HFSEs), and large ion lithophile elements (LILEs), but also due to the occurrence of key minerals which are common in peralkaline rocks (e.g., $\mathrm{Na}$-clinopyroxene, $\mathrm{Na}$-amphibole, and aenigmatite), and their unusually fluid rheological behavior (e.g., Carmichael, 1962; Nicholls and Carmichael, 1969; Macdonald, 1974a; Sutherland, 1974; Kogarko, 1980; Sørensen, 1992; Dingwell et al., 1998; Bailey et al., 2001; Di Genova et al., 2013; Marks and Markl, 2017). These peralkaline rocks may be divided broadly into three groups: (1) the $\mathrm{SiO}_{2}$-undersaturated group which evolves toward foid-bearing phonolites and foidites, (2) the $\mathrm{SiO}_{2}$-saturated group which evolves toward trachytic compositions, and (3) the $\mathrm{SiO}_{2}$-oversaturated group which evolves toward comenditic and pantelleritic trachytes and rhyolites, all three groups having their own intrusive equivalents (Le Maitre, 2003; Frost and Frost, 2008). Regardless of silica saturation, the peralkaline rocks may also be defined based upon mineralogy; if the HFSEs are hosted in zircon and titanite the rock is termed miaskitic, whereas the occurrence of rare zirconosilicate minerals, (e.g., eudialyte-group minerals; Johnsen et al., 2003, and/or wöhlerite- or rinkitegroup minerals; Merlino and Perchiazzi, 1988; Sokolova and Cámara, 2017) defines the agpaitic rocks (Sørensen, 1960, 1997; Khomyakov, 1995; Marks and Markl, 2017). When compared with their metaluminous counterparts, peralkaline magmas are rare and less significant volumetrically. Despite this, they have attracted considerable attention from the academic community, with studies being devoted to magma genesis and evolution (e.g., Nicholls and Carmichael, 1969; Macdonald, 1974a, 2012; Baker and Henage, 1977; Larsen, 1979; Mahood and Hildreth, 1986; Macdonald et al., 1995, 2008, 2011, 2012; Bohrson and Reid, 1997; Sørensen, 1997; Markl, 2001; Scaillet and Macdonald, 2001; Avanzinelli et al., 2004; White et al., 2005; Macdonald and Scaillet, 2006; Pfaff et al., 2008; Markl et al., 2010; Marks et al., 2011; Rooney et al., 2012; Marks and Markl, 2015; Sliwinski et al., 2015; Wolff, 2017), eruptive behavior and degassing (e.g., Schmincke, 1974; Lowenstern, 1994; Barclay et al., 1996), and economic potential (e.g., Haffty and Noble, 1972; Pollard, 1995; Salvi and Williams-Jones, 2006; Goodenough et al., 2016).

The majority of reported peralkaline rocks are limited to locations such as the East African Rift, the Gardar Igneous Province (Macdonald, 1974b), Pantelleria Island (the type locality for pantellerite, a variety of strongly peralkaline rhyolite), and other localities such as the peralkaline granites of northern Corsica (e.g., Quin, 1962; Bonin et al., 1978), various peralkaline intrusive lithologies found within the alkaline province of central Europe and France (e.g., Brousse and Varet, 1966;
Wimmenauer, 1974; Bernth et al., 2002), the peralkaline granitic dykes of the Oslofjord province (e.g., Nystuen, 1975; Rasmussen et al., 1988; Neumann et al., 1992), and British Tertiary Igneous Province (e.g., Sabine, 1960; Thompson, 1969; Macdonald, 1974b; Ferguson, 1978). However, peralkaline rocks have also been reported in many oceanic island settings, including Iceland, Socorro, the Canary Islands, the Azores, Kerguelen and Easter Island (e.g., Schmincke, 1973; Baker, 1974; White et al., 1979; Bohrson et al., 1996). The comparable peralkaline character of these systems may imply that similar petrogenetic frameworks may be operating in all of these systems, regardless of their contrasting geodynamic settings (i.e., continental vs. oceanic).

In this study, we review the occurrence of peralkaline felsic magmatism in the Atlantic Ocean, utilizing published geochemical, thermobarometric, and geochronological datasets. Where possible, we provide new data by building upon existing datasets with original thermohygrometric and rheological calculations. The study aims to identify the primary controls on the formation of peralkaline felsic magmas in oceanic island magmatic systems and to evaluate the architecture of the magmatic systems from which they are derived. We consider peralkaline rocks from all large Atlantic Ocean volcanic centers, from Iceland in the north to Bouvet Island in the South, aiming to: (1) summarize the key petrological features of Atlantic peralkaline oceanic island magmatism, including magma genesis and storage conditions, (2) discuss recent progress in the scientific understanding of how such magmatic systems originate and evolve through time, and (3) produce an original petrogenetic model which can account for the observed petrological features. Due to the considerable interest in the OIBs of these ocean island volcanic centers, the corresponding evolved compositions (where present) are in some cases somewhat under-studied in comparison. As such, the available datasets for peralkaline felsic rocks exhibit significant diversity in their respective sizes, ranging inevitably from detailed (e.g., Canary Islands) to sparse (e.g., Bouvet Island). Nevertheless, the available data do allow comparison between each of the eruptive centers of the study, facilitating a broad review of the peralkaline magmatism of the Atlantic Ocean as a whole.

\section{PERALKALINE ROCKS OF THE ATLANTIC OCEAN ISLANDS}

For the purpose of this study, we utilize thirteen examples of oceanic island magmatism from the Atlantic Ocean (Figure 1), where the described rocks are peralkaline sensu stricto, or have a peralkaline affinity, a term we apply qualitatively here for rocks (typically trachytes, phonolites, and rhyolites) which approach peralkalinity, typically with a peralkalinity index between 0.9 and 1.0. We consider the latter to be of importance as they may represent felsic magmas which act as progenitors to the peralkaline felsic compositions, either by representing a single step on an evolutionary trend from mafic to felsic compositions, or as a directly derived composition that may then evolve further (e.g., crustal melting followed by fractional crystallization; Bohrson and Reid, 1997; 


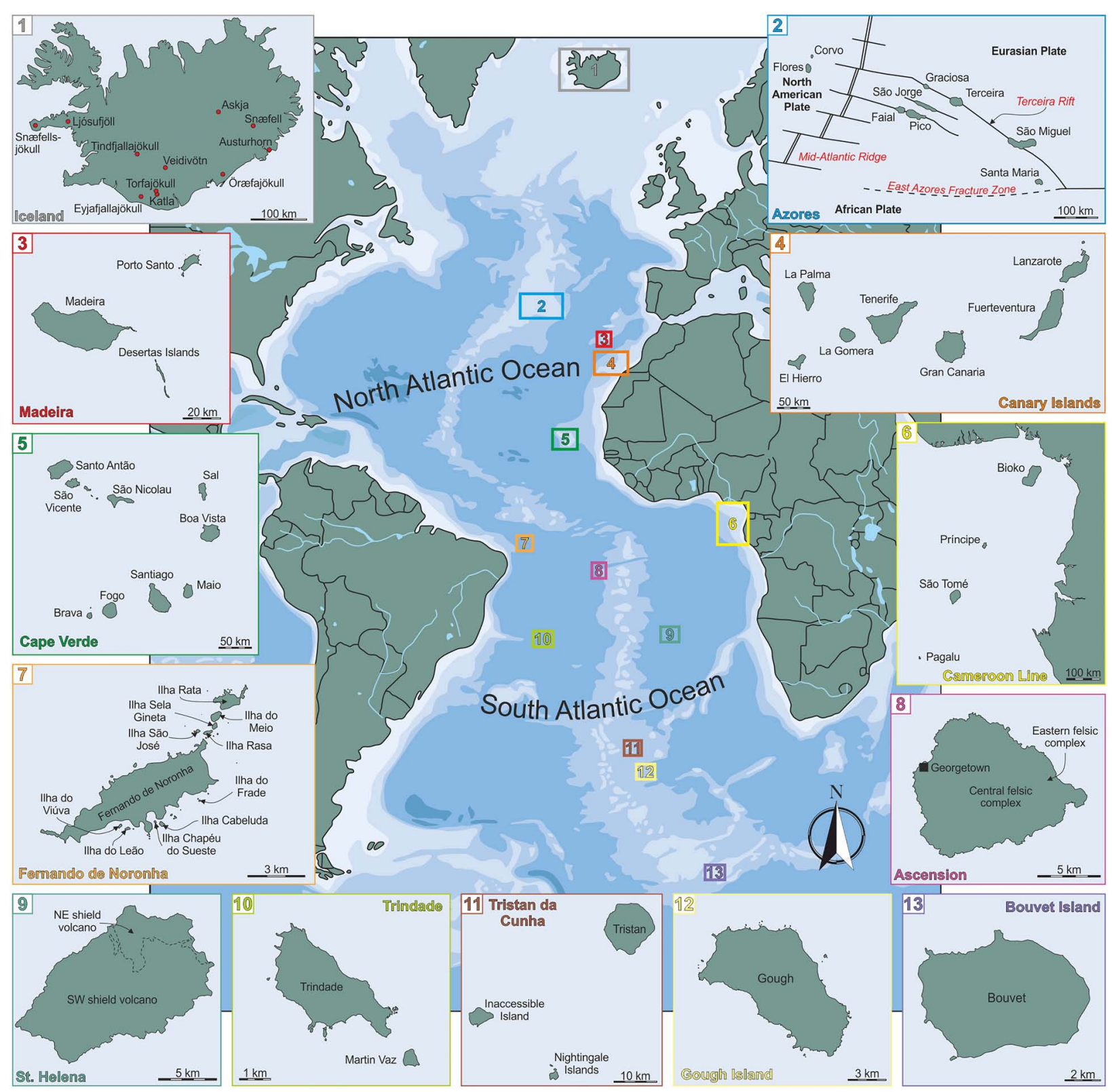

FIGURE 1 | Summary geographical maps showing each of the Atlantic Ocean island magmatic systems used as case studies in this contribution: (1) Iceland (with locations of reported peralkaline magmatism marked), (2) the Azores archipelago, (3) the Maediera archipelago, (4) the Canary Islands, (5) the Cape Verde archipelago, (6) the oceanic sector of the Cameroon Line, (7) Fernando de Noronha, (8) Ascension Island, (9) St. Helena, (10) Trindade, (11) Tristan da Cunha, (12) Gough Island, and (13) Bouvet Island. Map after Ericson et al. (2017).

Trua et al., 1999; Avanzinelli et al., 2004). As such, magmatic systems that have produced rocks with peralkaline affinity might reasonably be expected to produce peralkaline rocks in the future. All literature data were collected from the GEOROC database ${ }^{1}$. Where possible, data quality was evaluated using major element totals; totals below $96 \%$ or above $102 \%$ were not considered further. Below, we provide a brief account of the geodynamic setting and overall geochemical trends of each of our selected

${ }^{1}$ http://georoc.mpch-mainz.gwdg.de/georoc/ case studies, presented in order from north to south. A summary of the total combined dataset (e.g., published data supplemented with data from this study) is given in Table 1.

\section{Iceland}

Iceland is the largest of the Atlantic oceanic islands, comprising a submarine plateau that covers $\sim 3.5 \times 10^{5} \mathrm{~km}^{2}$ and rises more than $3000 \mathrm{~m}$ above the surrounding sea floor (Gudmundsson, 2000 and references therein). Of this area, $\sim 1.3 \times 10^{5} \mathrm{~km}^{2}$ is exposed subaerially. Magmatism in the 


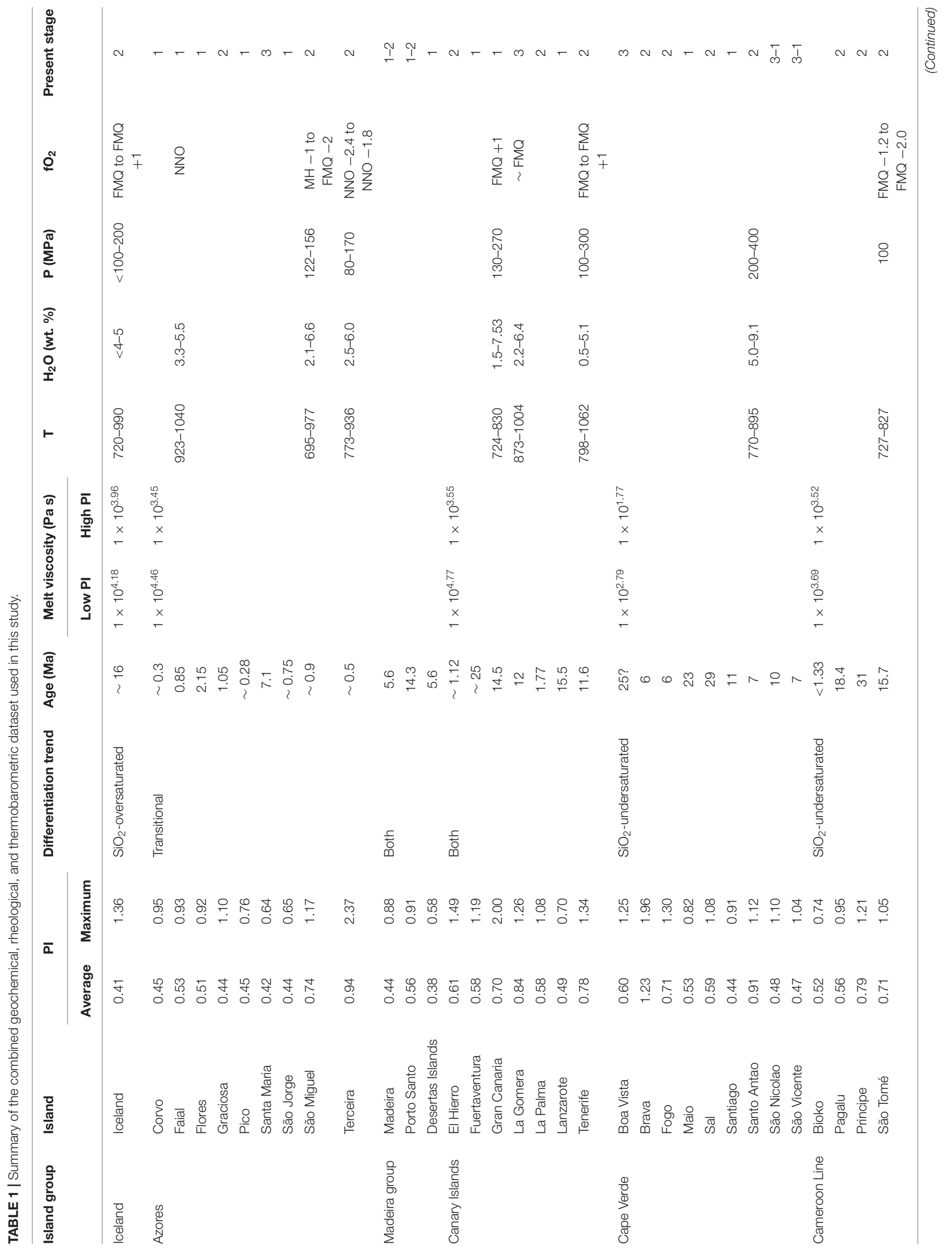




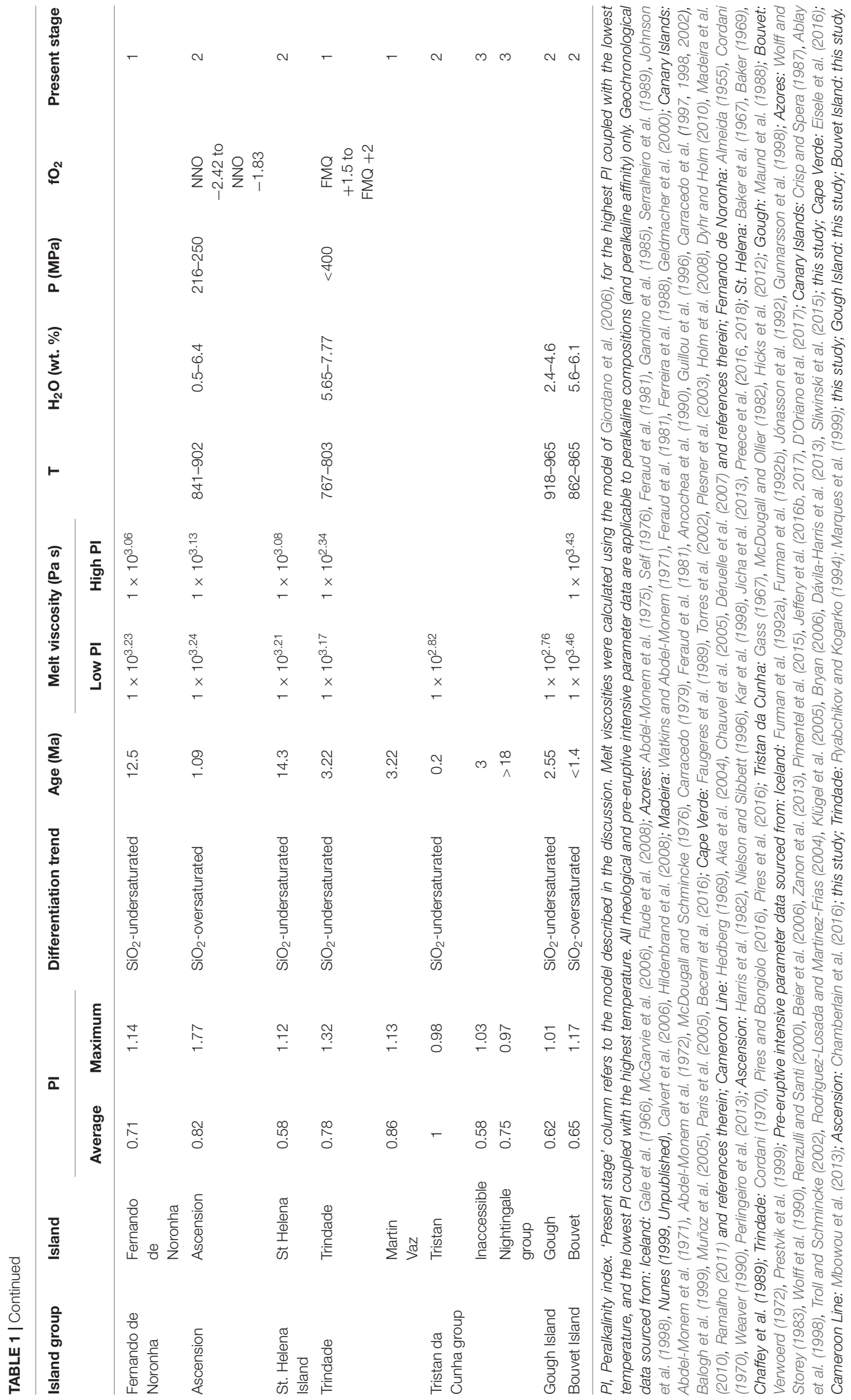




\begin{tabular}{|c|c|}
\hline \|celand & Iceland \\
\hline Azores & $\begin{array}{l}\text { Terceira } \\
\text { São Miguel } \\
\text { São Jorge Santa Maria } \\
\text { Pico } \\
\text { Graciosa } \\
\text { Flores } \\
\text { Faial } \\
\text { Corvo }\end{array}$ \\
\hline Madeira & \begin{tabular}{|c|c|c|} 
Desertas Islands \\
Madeira
\end{tabular} \\
\hline $\begin{array}{l}\text { Canary } \\
\text { lslands }\end{array}$ & 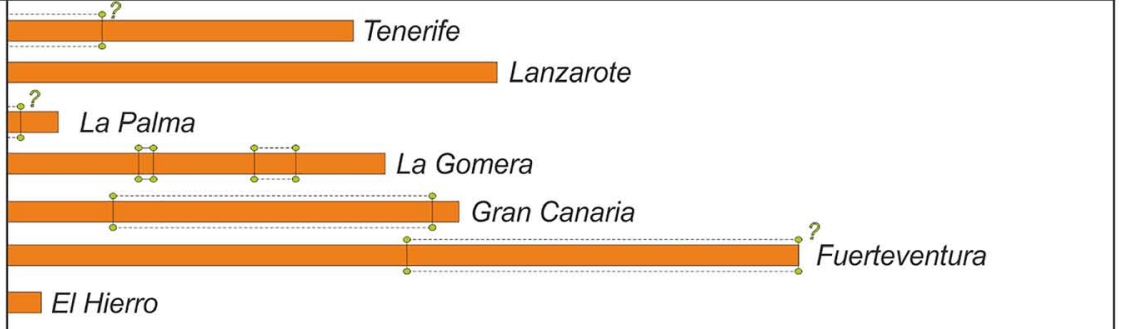 \\
\hline $\begin{array}{l}\text { Cape } \\
\text { Verde }\end{array}$ & 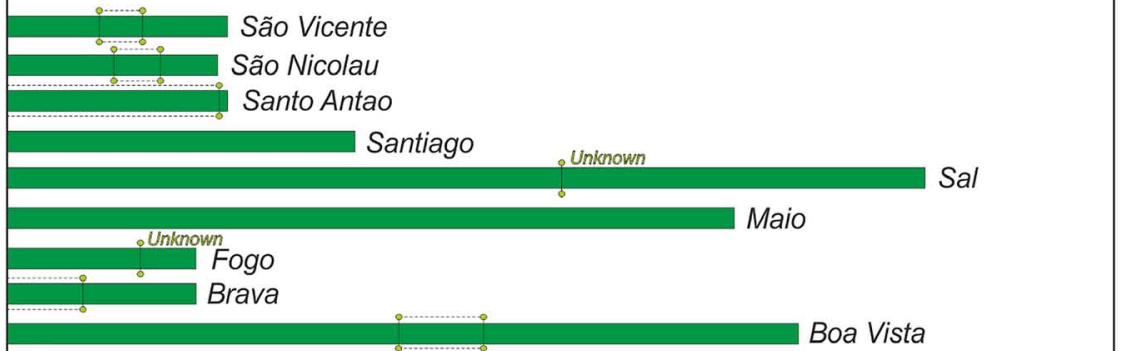 \\
\hline $\begin{array}{c}\text { Cameroon } \\
\text { Line }\end{array}$ & 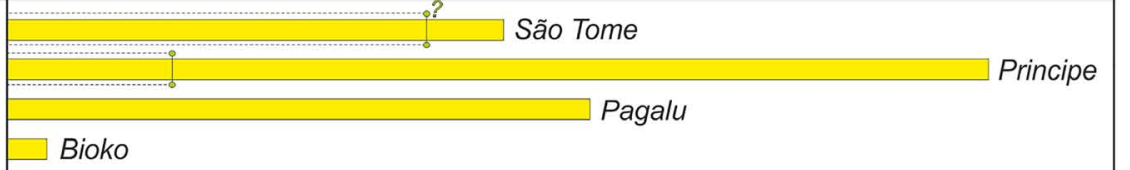 \\
\hline $\begin{array}{l}\text { Ferm. de } \\
\text { Noronha }\end{array}$ & 的 Fernando de Noronha \\
\hline Ascension & $\ldots$ Ascension \\
\hline St. Helena & $1+1-1+1-1+1$ \\
\hline Trindade & $\begin{array}{l}\int_{0} \text { Martin Vaz } \\
a \ldots \text { Trindade }\end{array}$ \\
\hline $\begin{array}{c}\text { Tristan da } \\
\text { Cunha }\end{array}$ & Nightingale Islands \\
\hline $\begin{array}{l}\text { (Gough } \\
\text { [s]and } \\
\text { Bouvet } \\
\text { Island } \\
\end{array}$ & \begin{tabular}{|l|} 
Gough Island \\
Bnknown \\
\end{tabular} \\
\hline & 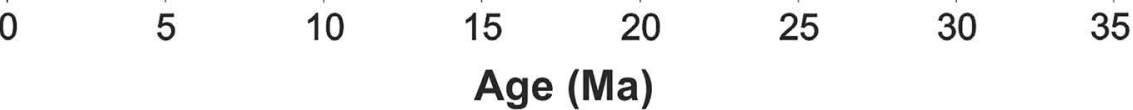 \\
\hline
\end{tabular}


FIGURE 2 | Summary figure showing the various subaerial ages of each of the individual volcanic islands of the Atlantic Ocean. The earliest known eruption of felsic magmas is marked for each island with a green, double-ended pin mark, highlighting the first known opportunity for peralkaline magmatism to occur. Where possible, the total temporal range of felsic magmatism is shown with dashed lines which delineate a field. Data sources are as follows: Iceland: Gale et al. (1966), McGarvie et al. (2006), Flude et al. (2008); Azores: Abdel-Monem et al. (1975), Self (1976), Feraud et al. (1981), Gandino et al. (1985), Serralheiro et al. (1989), Johnson et al. (1998), Nunes (1999, Unpublished), Calvert et al. (2006), Hildenbrand et al. (2008); Madeira: Watkins and Abdel-Monem (1971), Feraud et al. (1981), Ferreira et al. (1988), Geldmacher et al. (2000); Canary Islands: Abdel-Monem et al. (1971), Abdel-Monem et al. (1972), McDougall and Schmincke (1976), Carracedo (1979), Feraud et al. (1981), Ancochea et al. (1990), Guillou et al. (1996), Carracedo et al. (1998), Carracedo et al. (2002), Balogh et al. (1999), Muñoz et al. (2005), Paris et al. (2005), Becerril et al. (2016), Cape Verde: Faugeres et al. (1989), Torres et al. (2002), Plesner et al. (2003), Holm et al. (2008), Dyhr and Holm, 2010, Madeira et al. (2010), Ramalho (2011) and references therein; Cameroon Line: Hedberg (1969), Aka et al. (2004), Chauvel et al. (2005), Déruelle et al. (2007) and references therein; Fernando de Noronha: Almeida (1955), Cordani (1970), Weaver (1990), Perlingeiro et al. (2013); Ascension: Harris et al. (1982), Nielson and Sibbett (1996), Kar et al. (1998), Jicha et al. (2013), Preece et al. (2016, 2018); St. Helena: Baker et al. (1967), Baker (1969), Chaffey et al. (1989); Trindade: Cordani (1970), Pires and Bongiolo (2016), Pires et al. (2016); Tristan da Cunha: Gass (1967), McDougall and Ollier (1982), Hicks et al. (2012); Gough: Maund et al. (1988); Bouvet: Verwoerd (1972), Prestvik et al. (1999).

area reflects interaction between the Mid-Atlantic Ridge and a mantle plume (e.g., Schilling, 1973; Vink, 1984; White et al., 1995; Bjarnason et al., 1996; Wolfe et al., 1997; Allen et al., 1999; Parnell-Turner et al., 2014), and began around $24 \mathrm{Ma}$ (Sæmundsson, 1978, 1979; Jóhannesson, 1980; Kristjánsson, 1982; Óskarsson et al., 1985), although the oldest dated subaerial rocks are up to $16 \mathrm{Ma}$ (Moorbath et al., 1968; Watkins and Walker, 1977; McDougall et al., 1984; Figure 2). Volcanism is focussed in the neovolcanic zones, which represent the surface expression of this plume-ridge interaction (Sæmundsson, 1979; Vink, 1984; Óskarsson et al., 1985; Hardarson et al., 1997). The most prominent of these is the axial volcanic zone, which represents the boundary between the North American and Eurasian plates, and thus marks the focus of active spreading. In addition to the axial rift zone, two off-rift volcanic belts exist; the Öræfi Volcanic Belt in the east, which may reflect an embryonic rift (Thordarson and Hoskuldsson, 2002), and the Snæfellsnes Volcanic Belt in the west, which is an old, reactivated rift zone (Gudmundsson, 2000). Volcanism across Iceland includes polygenetic central volcanoes (e.g., Snæfellsjökull, Krafla, Askja, Torfajökull), as well as monogenetic vents including fissures, maars, and scoria cones (Thorarinsson and Sæmundsson, 1979; Thorarinsson, 1981; Thordarson and Larsen, 2007).

The magmatism of Iceland ranges from basalt to rhyolite and, unlike the other Atlantic Ocean islands, generally adheres to a subalkaline tholeiitic trend (Figure 3A), particularly in the NE portion of the axial rift zone. Magmatism becomes mildly alkaline toward the SW of the axial rift, and also in the two off-rift volcanic belts (the Öræfi Volcanic Belt and the Snæfellsnes Volcanic Belt; Jakobsson, 1979; Sæmundsson, 1979; Gudmundsson, 1995). Mafic eruptive products are volumetrically dominant, with a lesser contribution of intermediate and felsic products (Walker, 1959, 1963, 1966; Carmichael, 1964; Baker, 1974). The most recent (since $\sim 900$ A.D.) eruptive products of Iceland as a whole, together comprising some $122 \mathrm{~km}^{3}$ in volume, were estimated to include $\sim 79$ vol. \% mafic magma, with intermediate compositions accounting for $\sim 16$ vol. $\%$, and felsic magmas making up the remaining 5 vol. \% (Thorarinsson and Sæmundsson, 1979; Thordarson and Larsen, 2007). Peralkaline felsic magmatism (typically comendites but also some reported pantellerites; e.g., McGarvie et al., 2006) is restricted to polygenetic volcanic centers (Jónasson, 2007), such as Askja
(Hartley et al., 2016), Katla (Larsen et al., 2001; Lacasse et al., 2007), Ljósufjöll (Flude et al., 2008), and Torfajökull (McGarvie, 1984; Macdonald et al., 1990; McGarvie et al., 1990, 2006).

\section{Azores}

The Azores archipelago comprises nine islands located in the central North Atlantic Ocean (São Miguel, Santa Maria, Terceira, Pico, Graciosa, Faial, São Jorge, Corvo, and Flores). The islands themselves represent the subaerial expression of the Azores Plateau, a bathymetric and gravity anomaly denoting a morphologically complex area $\left(\sim 5.8 \times 10^{6} \mathrm{~km}^{2}\right)$ of thickened oceanic crust that formed between 20 and $7 \mathrm{Ma}$ (e.g., Kaula, 1970; Krause and Watkins, 1970; Luis et al., 1994; Gente et al., 2003). The plateau is broadly triangular in shape, bounded by three major tectonic features; the Mid-Atlantic Ridge in the west, the East Azores Fracture Zone to the south and the Terceira Rift to the north-east (Krause and Watkins, 1970). Together these structures mark a triple junction between the North-American, Eurasian and Nubian plates (e.g., Vogt and Jung, 2004; Marques et al., 2013; Hildenbrand et al., 2014; Fernandes et al., 2018). The islands are relatively young amongst those of the Atlantic Ocean (Figure 2), and typically exhibit relatively youthful forms, with well-defined volcanic edifices. The notably older and heavily eroded island of Santa Maria (7.1 Ma; Abdel-Monem et al., 1975) stands in exception to this (e.g., Ramalho et al., 2017).

Magmatism in the Azores has been the subject of numerous scientific studies, particularly in recent years (e.g.; White et al., 1979; Madureira et al., 2011; Beier et al., 2013; Métrich et al., 2014; Larrea et al., 2014a, 2018; Zanon, 2015). The majority of the subaerially erupted magmas of the Azores archipelago have been mafic in composition, ranging from basalt/alkali basalt to hawaiite, which typically form lava flows, cinder cones, and spatter ramparts (e.g., Booth et al., 1978; Zanon et al., 2013). Felsic magmas have been erupted primarily via Plinian or subPlinian activity from the central vents of the various volcanic complexes (e.g., Self, 1976; Guest et al., 1999; Gertisser et al., 2010; Pimentel, 2015; Pimentel et al., 2015). Felsic magmas have also been erupted effusively, forming lava domes and coulées (e.g., Self, 1974, 1976; Booth et al., 1978; Pimentel, 2006).

When considered as a whole, the Azorean suite ranges from 40 to $\sim 68$ wt. $\% \mathrm{SiO}_{2}$, forming an alkaline magma series from basalt or alkali basalt to trachyte, with some basanites 


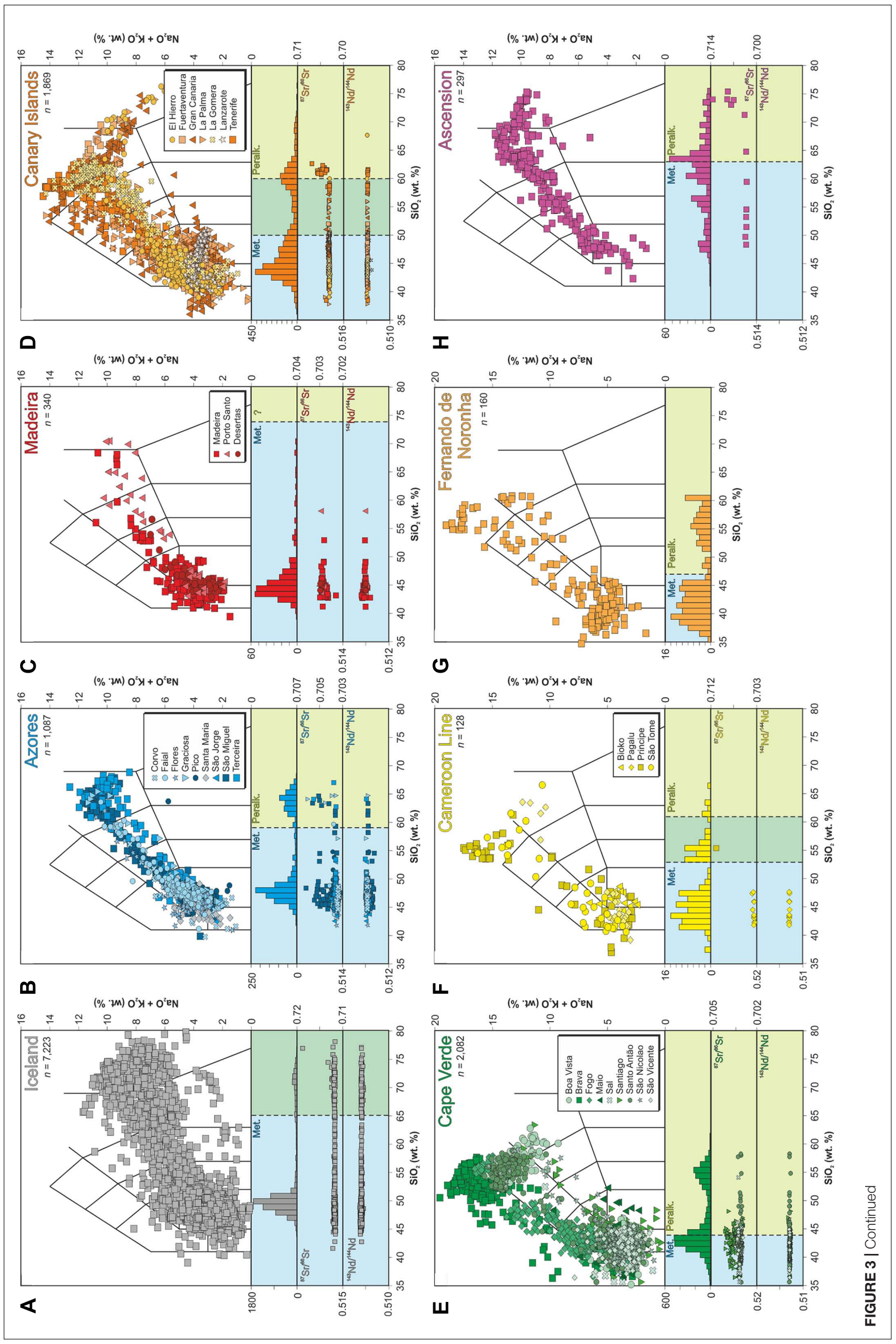




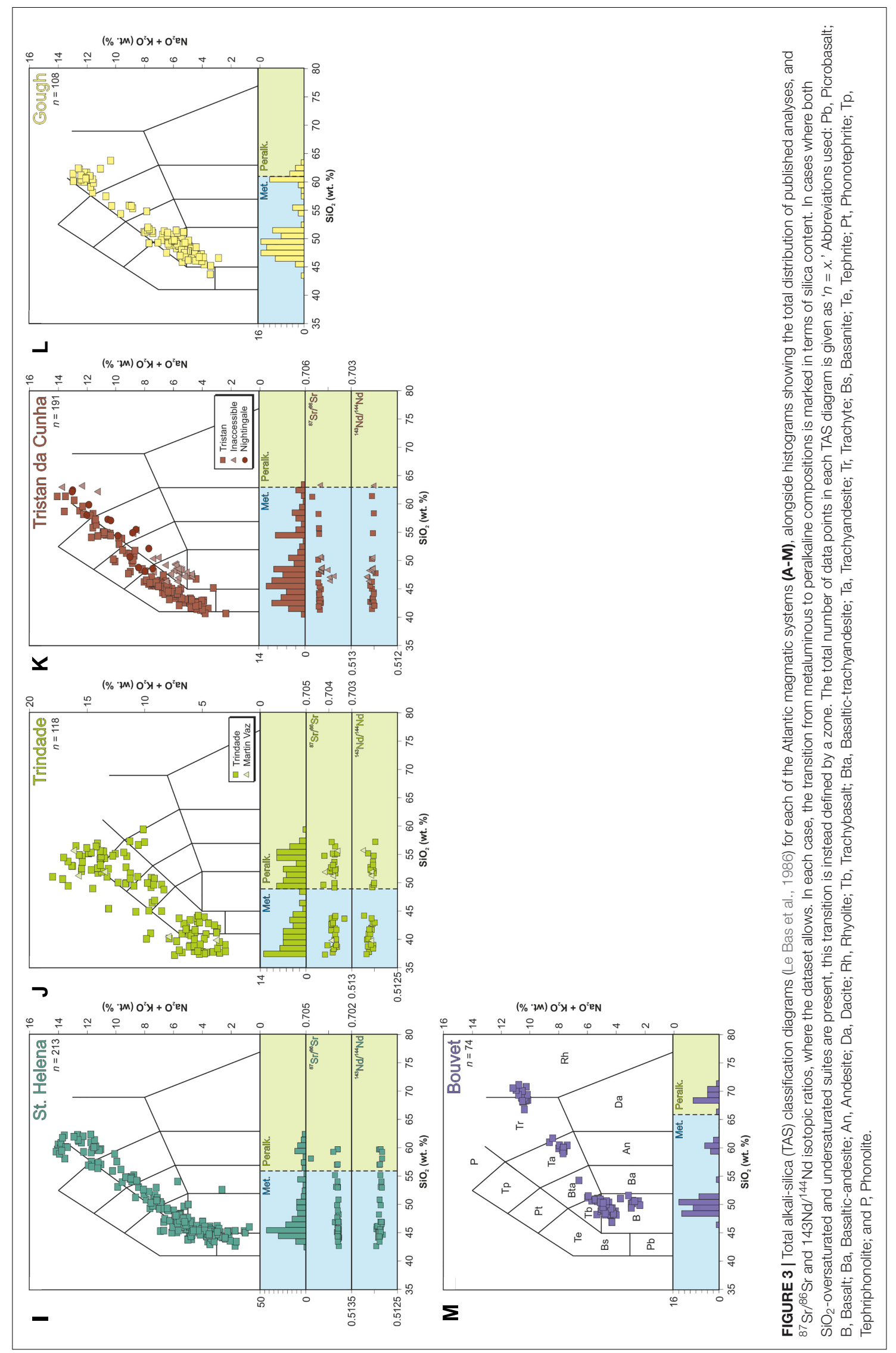


on Santa Maria. Total alkali contents lie between 1.7 and 13.5 wt. \% (Figure 3B), and $\mathrm{Na} / \mathrm{K}$ ratios exceed unity. White et al. (1979) highlight the presence of a 'Daly gap', describing bimodal eruptive products with a relative lack of intermediate. Mafic products have been generally erupted from fissural zones, and range from sub-aphyric to highly porphyritic with abundant olivine and clinopyroxene phenocrysts and xenocrysts, as well as glomerocrysts of varying composition (e.g., Genske et al., 2012; Larrea et al., 2013; Zanon and Frezzotti, 2013; Zanon et al., 2013; Zanon, 2015). Intermediate magmas are infrequent in occurrence, but have been described in some detail on São Miguel (Beier et al., 2006), Faial (Zanon et al., 2013), Corvo (Larrea et al., 2013), Graciosa (Zanon, 2015), Flores (Genske et al., 2012), and Terceira (Mungall, 1993). Mugearitic compositions are often highly porphyritic ( 30 vol. \%), but benmoreitic compositions are frequently close to aphyric. In contrast to the mafic magmas, the trachytic magmas are generally sub-aphyric to aphyric, with phase assemblages which are invariably dominated by alkali feldspar. Variably peralkaline syenitic autoliths are also described in both mafic and felsic lithologies (e.g., Self, 1976; Booth et al., 1978; Mungall, 1993; Gertisser et al., 2010; Jeffery et al., 2016a).

\section{The Madeira Archipelago}

The Madeira archipelago comprises five islands (Madeira, Porto Santo, and the three Desertas Islands), located in the eastern North Atlantic Ocean, $\sim 700 \mathrm{~km}$ west of the African coastline. The islands sit upon $140 \mathrm{Ma}$ old oceanic crust (Pitman and Talwani, 1972), rise $\sim 4 \mathrm{~km}$ from the sea floor, and mark the south-western end of a northeast-southwest trending alignment of seamounts and islands which extends for $\sim 700 \mathrm{~km}$, with a width of $\sim 200 \mathrm{~km}$ (Geldmacher et al., 2005). The chain extends from mainland Portugal to the Madeira archipelago, and exhibits a crude age progression of $\sim 72 \mathrm{Ma}$ (the Serra de Monchique igneous complex) to the present day (Madeira), which is typically interpreted as evidence for an underlying mantle plume (Morgan, 1981).

Together, Madeira and the Desertas islands are often considered to represent a single volcanic system (although geobarometric studies may provide evidence for two separate systems; Schwarz et al., 2004), dated at up to $5.6 \mathrm{Ma}$ (e.g., Watkins and Abdel-Monem, 1971; Feraud et al., 1981; Ferreira et al., 1988; Figure 2), and comprising two rift arms: the Desertas Rift which trends NNW-SSE, and the E-W trending Madeira Rift (Geldmacher and Hoernle, 2000). The temporal evolution of this volcanic center was divided by Geldmacher et al. (2000) into two key portions: (1) the shield stage ( $>4.6$ to $0.7 \mathrm{Ma}$ ), which accounts for $99.5 \%$ of the subaerial volume, and (2) the post-erosional phase $(<0.7 \mathrm{Ma})$. The majority of volcanism on Madeira took place from 3.9 to $4.6 \mathrm{Ma}$, and 0.7 to $3 \mathrm{Ma}$, during the Early and Late Madeira rift phases, respectively. The formation of the Desertas islands occurred primarily between 3 and $4 \mathrm{Ma}$, during which time the Madeira Rift was inactive. The rocks of both islands adhere to the $\mathrm{SiO}_{2}$-oversaturated trend, and are dominated by mildly alkaline picrites and basanites, with comparatively rare intermediate or felsic rocks including mugearite, benmoreite, and trachyte (Schwarz et al., 2004; Figure 3C). The mafic lithologies typically contain phenocrystic olivine and clinopyroxene, with plagioclase being present only in the basalts and hawaiites.

The stratigraphy of Madeira Island is divided into seven unconformity-bounded units, which are themselves grouped into the Lower, Middle, and Upper Volcanic Complexes (Brum da Silveira et al., 2010a,b,c). Within these formations, basaltic compositions are dominant. The Lower Volcanic Complex includes strongly altered hydrovolcanic rocks and marine sediments, and may represent the seamount-building stage of Madeira. The Middle Volcanic Complex (representative of the shield-building phase) comprises various lava flow successions and tephra layers which gradually became more intermediate in composition over time. The Upper Volcanic Complex is made up of topography-filling volcanic lava flows and scoria cones, representative of the erosional phase of the island (Czajkowski, 2002; Ramalho et al., 2015).

The island of Porto Santo lies $45 \mathrm{~km}$ to the northeast of Madeira, and reflects a distinct, older (11.1-14.3 Ma; Geldmacher et al., 2000; Figure 2) volcanic edifice. Unlike Madeira and the Desertas Islands, the compositional range of the rocks of Porto Santo extends from basalts to metaluminous trachytes. The northeast of the island comprises a predominantly submarine cone, with various trachytic and basaltic intrusions. By contrast, the lavas originating from the southwestern center are primarily mafic to intermediate (Czajkowski, 2002).

\section{The Canary Islands}

The Canary Island archipelago comprises seven volcanic islands (La Palma, El Hierro, Gomera, Tenerife, Gran Canaria, Fuerteventura, and Lanzarote), as well as a number of sea mounts, trending roughly WSW-ENE between 100 and $500 \mathrm{~km}$ from the coast of NW Africa, in an $\sim 800 \mathrm{~km}$ long, $\sim 400 \mathrm{~km}$ wide volcanic belt (Hoernle and Carracedo, 2009). The archipelago has received considerable attention from the scientific community, and has been the subject of numerous tectonic, petrological, volcanological, and geochronological studies (e.g., McDougall and Schmincke, 1976; Schmincke, 1976; Ancochea et al., 1990; Martí et al., 1994; Carracedo et al., 1998, 2002, 2007, 2011; Bryan et al., 2000; Thirlwall et al., 2000; Brown et al., 2003; Brown and Branney, 2004; Triebold et al., 2006; Edgar et al., 2007; Meletlidis et al., 2012; Longpré et al., 2014; Barker et al., 2015; Cooper et al., 2015; Troll and Carracedo, 2016). The easternmost islands of Fuertaventura and Lanzarote are underlain by transitional oceanic-continental crust, whereas the remaining islands overly oceanic crust (Robertson and Stillman, 1979; Ye et al., 1999), constrained in age to the Jurassic by magnetic anomalies S1 (175 Ma, located between the easternmost islands and the African coastline) and M25 (155 Ma, located between La Palma and El Hierro) (Klitgord and Schouten, 1986). A substantial radiometric dataset indicates that magmatism in the area began more than 20 m.y. ago, forming the eastern islands of Lanzarote and Fuerteventura (e.g., Abdel-Monem et al., 1971; Schmincke, 1976; Ancochea et al., 1999 and references therein; Geldmacher et al., 2005). Overall, the islands become younger toward the west, with the oldest subaerial volcanism for Fuerteventura, 
Lanzarote, and Gran Canaria being constrained to 20.6, 15.5, and 13.7 Ma, respectively, compared with 2.0 and $1.12 \mathrm{Ma}$ for $\mathrm{La}$ Palma and El Hierro, respectively (McDougall and Schmincke, 1976; Carracedo et al., 1998; Figure 2). Due to their age and morphologies, the eastern islands (Gran Canaria, Fuerteventura, and Lanzarote) are considered to be in a post-erosional stage, with a net decrease in the size of the island. By contrast, the western islands of El Hierro, La Palma, and Tenerife are each regarded as being in a constructive (shield) stage (e.g., Ancochea et al., 1990), with net growth of the edifice. La Gomera is intermediate between the two stages, due to an identified postshield gap in volcanic activity (Carracedo et al., 1998) and an age of 9.4 Ma (Paris et al., 2005).

Chemically, the Canary Islands are arguably the most diverse of the Atlantic volcanic centers, with rock types including basanites, basalts (both alkali and tholeiitic), tephrites, nephelinites, melilitites, trachyandesites, rhyolites, trachytes, phonolites, comendites, pantellerites, and carbonatites (Figure 3D). Together, these lithologies define multiple evolutionary trends ranging from $\mathrm{SiO}_{2}$-undersaturated (e.g., basanite to phonolite) to $\mathrm{SiO}_{2}$-oversaturated (basalt to rhyolite) (e.g., Carracedo et al., 2002). Furthermore, a tholeiitic trend similar to that of Hawaii is recognized on a number of islands, where it has been linked to greater fusion rates, and assimilation of silicic crustal sediments (Carracedo et al., 2002; Aparicio et al., 2006, 2010; Troll et al., 2012; Troll and Carracedo, 2016). There is considerable variation in the geochemistry of eruptive deposits between the islands (Carracedo et al., 2002). For example, Gran Canaria exhibits the full range of compositions, including highly alkaline, mildly alkaline, and tholeiitic varieties. In contrast, the other islands exhibit more simplistic trends (Figure 3D). El Hierro, La Gomera, Lanzarote, and Fuertaventura display only mildly alkaline trends, compared with Tenerife and La Palma, which become more alkaline in nature. The abundance of felsic rocks is also variable, being greatest on Gran Canaria and Tenerife, and smallest on Lanzarote.

\section{Cape Verde}

The Cape Verde archipelago comprises nine islands (Santo Antão, São Vicente, São Nicolau, Sal, Boa Vista, Maio, Santiago, Fogo, and Brava) and eight minor islets, situated in the central Atlantic, approximately $450 \mathrm{~km}$ from the western coast of Africa. The islands sit on oceanic crust that ranges in age from 120 to 140 $\mathrm{Ma}$ (Müller et al., 2008), and represent the subaerial portion of the Cape Verde rise, a dome-shaped swell which is elevated by 2.2$2.4 \mathrm{~km}$ relative to the surrounding seafloor, and which occupies more than $300,000 \mathrm{~km}^{2}$ (Crough, 1982; McNutt, 1988). Although traditionally divided based upon geographical position (the Windward Group and the Leeward Group), regional bathymetry indicates that two submarine chains exist: the northern chain which runs NW to SE and includes Santo Antão, São Vicente, Santa Luzia, and São Nicolau, and the curved southern chain, which runs broadly ENE to WSW before curving northward, and is composed of the islands of Sal, Boa Vista, Maio, Santiago, Fogo, and Brava (Ramalho, 2011).

The eastern islands generally exhibit flattened, eroded forms, suggesting that they are in a post-erosional stage.
Moving westward, the islands become progressively youthful in appearance, with greater topographical relief and higher elevations. This is in accordance with available ages for each island (Ramalho, 2011 and references therein), which indicate that Sal, Maio, and potentially Boa Vista are the oldest islands, with a maximum age of $\sim 26 \mathrm{Ma}$ (Torres et al., 2002; Figure 2). This age also coincides with the formation of the Cape Verde Rise (Faugeres et al., 1989). Around 8-10 Ma, volcanism was initiated further westward, leading to the development of Santiago and São Nicolau, and later ( $\sim 4$ to $6 \mathrm{Ma})$, the broadly synchronous formation of the remaining islands (Holm et al., 2008; Ramalho, 2011). Modern day volcanic activity within the archipelago is limited to Fogo, where the primary eruptive center (Pico do Fogo) has erupted every 20 years, on average, since the island was settled, with the most recent eruption having occurred in 20142015 (e.g., Torres et al., 1997; Hildner et al., 2011; González et al., 2015).

The rocks of the Cape Verde archipelago are almost exclusively strongly silica-undersaturated, and range from picrites to peralkaline phonolites and trachytes (Ramalho, 2011; Figure 3E). Two magmatic series are identified; (1) a high alkali series comprising picrites, foidites, and phonolites, and (2) a moderately alkaline series comprising picrobasalts, basanites, tephrites, tephrophonolites, phonotephrites, phonolites, and trachytes (Kogarko, 2008). The plutonic cores of heavily eroded volcanic edifices are similar in composition, ranging from gabbro to syenite (Serralheiro, 1976). Not all of the islands exhibit the entire compositional range of the archipelago; for example, São Vicente is limited to mafic rocks, whereas Brava is dominated by peralkaline phonolites. Cape Verde also exhibits carbonatitic rocks, which are found in both the basement complexes and the mature stages of at least 5 of the 10 islands (Jørgensen and Holm, 2002; Mourão et al., 2010, 2012; Weidenorfer et al., 2016; Mata et al., 2017).

\section{Cameroon Line}

The Cameroon Line comprises a 1,600 km long, Y-shaped chain of intraplate volcanic centers with a broadly NE-SW alignment. This feature extends across both continental and oceanic crust, with both portions being believed to have formed simultaneously, beginning at around $52 \mathrm{Ma}$ (Moundi et al., 2007; Yokoyama et al., 2007). Unlike other alignments of oceanic islands, there is no evidence for age progression along the Cameroon Line (Lee et al., 1994; Marzoli et al., 2000). The chain includes two sectors: the continental sector, which comprises a number of large massifs, including the currently active Mt. Cameroon (Suh et al., 2003), and the oceanic sector, which includes four volcanic islands (Pagalú, São Tomé, Principe, and Bioko) and two seamounts (Déruelle et al., 1991; Lee et al., 1994; Burke, 2001). Overall, the rocks of the Cameroon Line range from mafic compositions, including alkali basalts, picrites, hawaiites, through to felsic compositions such as phonolites, trachytes, and rhyolites, with comparatively less common intermediate compositions (mugearites, benmoreites) (Déruelle et al., 2007; Figure 3F). Unlike the mafic rocks, the felsic rocks exhibit clear spatial variation between the two sectors. The felsic rocks of the Oceanic Sector are primarily phonolites and trachytes, with 
no rhyolitic compositions reported (Lee et al., 1994; Déruelle et al., 2007). By contrast, the continental sector includes primarily rhyolites and trachytes, leading some authors to invoke the role of varying degrees of crustal assimilation during fractional crystallization (e.g., Fitton, 1987). The proportion of felsic rocks relative to mafic rocks is generally recognized to increase to the SW and the NW of the boundary between the two sectors (e.g., in the vicinity of Bioko island). In this study, only the Oceanic Sector is considered.

Amongst the four islands of the Oceanic Sector, Bioko stands apart due to its young age ( $<1.33 \mathrm{Ma}$; Hedberg, 1969; Aka et al., 2004; Chauvel et al., 2005), youthful morphology, and exclusively mafic composition. By contrast, the three islands of Principe, São Tomé, and Pagalú are significantly older, reaching ages of 31 , 16, and $20 \mathrm{Ma}$, respectively (Déruelle et al., 2007 and references therein; Figure 2). These three islands also exhibit more variation in the compositions of their eruptive lavas, ranging from basalt to trachyte and phonolite. The occurrence of peralkaline magmatism is limited to Principe and São Tomé, where mildly peralkaline phonolites are reported, although trachytes with a peralkaline affinity are also recognized on Pagalú.

\section{Fernando de Noronha}

The Fernando de Noronha archipelago is located $\sim 350 \mathrm{~km}$ ENE from the coast of Brazil, and comprises 21 individual islands and islets that have a cumulative surface area of 18.4 $\mathrm{km}^{2}$ and rise $\sim 4.2 \mathrm{~km}$ from the ocean floor (Bryan et al., 1972). The archipelago lies at the eastern end of a linear chain of seamounts, named the Fernando de Noronha Ridge, which extends eastward from the Brazilian mainland. Magmatism situated at the westernmost end of this ridge is dated at 40 $\mathrm{Ma}$, and is believed to represent the earliest activity of a mantle plume (the Fernando de Noronha plume) which later led to the formation of the archipelago of the same name (Fodor et al., 1998; Almeida, 2012; Lopes and Ulbrich, 2015).

The stratigraphy of the islands is divided into three distinct formations. The Remédios Formation comprises abundant, highly altered trachytic/phonolitic pyroclastic material, intruded by several dyke systems (lamprophyre, tephrite, basanite, trachyte, and trachyandesite), and various plugs and subvolcanic domes (phonolite, trachyte, basalt) (Almeida, 1955; Weaver, 1990; Ulbrich, 1993). Available ${ }^{40} \mathrm{Ar} /{ }^{39} \mathrm{Ar}$ ages indicate a range of 12.5-9.4 Ma for the Remédios Formation (Perlingeiro et al., 2013; cf. 12.3-8 Ma $\left({ }^{40} \mathrm{~K}-{ }^{40} \mathrm{Ar}\right)$; Cordani, 1970). Above the Remédios Formation, and separated from it by a significant period of erosion, is the Quixaba Formation, which comprises extensive nepheline-basalt flows which formed between 6.2 and 1.3 Ma, with minor nephelinite dykes, tuffs, and breccias (Almeida, 1955; Weaver, 1990; Perlingeiro et al., 2013). The third formation is the São José Formation, which comprises a series of basanitic lava flows exposed exclusively on the islet of São José, NE of the main island. Almeida (1955) identified this formation as distinct on the basis of often abundant mantle xenoliths, and it has subsequently been suggested to represent the youngest portion of the Quixaba Formation (Ulbrich, 1993; Lopes, 2002). However, recent ${ }^{40} \mathrm{Ar} /{ }^{39} \mathrm{Ar}$ ages indicate an age of 9.2-9.0 Ma, suggesting that they are in fact coeval with the Remédios Formation (Perlingeiro et al., 2013; Figure 2).

The geochemical evolution of the Fernando de Noronha archipelago is complex, and is summarized by Lopes et al. (2014) and Lopes and Ulbrich (2015) (Figure 3G). The Remédios Formation includes two suites of rocks, each derived from a discrete parental magma, and each exhibiting continuous geochemical trends from their least to their most evolved compositions; (1) the sodic series (basanite-tephritephonotephrite-phonolite), and (2) the moderately potassic series (alkali basalt-basaltic trachyandesite-trachyandesite-trachyte). Evidence for open system evolution, such as xenocrysts and autolithic fragments, is common throughout the formation. Lamprophyric dykes are distinct in that they bear no clear relationship to any of the other rock types. The overlying Quixaba and São José Formations are much more restricted in composition, comprising almost exclusively nephelinites and basanites, which correlate geochemically and appear to form a single suite, despite belonging to two distinct stages in the evolution of islands.

\section{Ascension}

Ascension Island lies approximately $90 \mathrm{~km}$ west of the MidAtlantic Ridge, in the Southern Atlantic Ocean. The $\sim 3,800$ $\mathrm{km}^{3}$ volcanic edifice rises $\sim 4 \mathrm{~km}$ from the sea floor, with only $1 \%$ of its total volume exposed subaerially (Harris, 1983; Klingelhöfer et al., 2001). Submarine volcanism is believed to have begun at $\sim 6$ to $7 \mathrm{Ma}$, with the edifice becoming subaerial at $\sim 1.09 \mathrm{Ma}$ (Jicha et al., 2013; Preece et al., 2016, 2018; Figure 2). The geology of the island is well described (e.g., Daly, 1925; Darwin, 1845; Atkins et al., 1964; Nielson and Sibbett, 1996; Weaver et al., 1996; Kar et al., 1998). Approximately 57\% of the island comprises effusive eruptive products (flows and domes), with the rest being pyroclastic lithologies (Harris, 1983). Mafic volcanic rocks are found across the island, whereas felsic eruptive products are found in two main areas; the Central Felsic Complex which forms the high ground in the island's center, and the Eastern Felsic Complex. There has been no historical volcanic activity on the island, although the youngest lava flows have recently been reliably dated at $<1 \mathrm{ka}$ (Preece et al., 2018).

The subaerial rocks of Ascension form a transitional to subalkaline series, ranging from basalt to rhyolite (Jicha et al., 2013; Figure $3 \mathbf{H}$ ). A general lack of intermediate compositions in the eruptive products of the island (a Daly Gap) has been observed, specifically within the compositional range of 58-63 wt. \% $\mathrm{SiO}_{2}$ (Daly, 1910, 1925). The mafic and intermediate lithologies are generally aphyric or sparsely phyric with phenocrystic plagioclase and olivine, with lesser clinopyroxene and $\mathrm{Fe}$-Ti oxides, and rare amphibole in the intermediate rocks only (Weaver et al., 1996). Based upon $\mathrm{Zr} / \mathrm{Nb}$ ratios, there are four distinct varieties of mafic rocks on Ascension, which are considered to reflect variation in the source characteristics beneath Ascension, despite erupting contemporaneously (Weaver et al., 1996; Kar et al., 1998). The felsic rocks, which account for $\sim 14 \%$ of the surface area of the island, are also generally aphyric or sparsely phyric, with alkali 
feldspar representing the most abundant phase (Weaver et al., 1996; Kar et al., 1998).

\section{St. Helena}

The island of St. Helena lies $\sim 750 \mathrm{~km}$ east of the MidAtlantic Ridge, and $\sim 1,900 \mathrm{~km}$ west of Africa. The island sits upon oceanic crust dated at $39 \mathrm{Ma}$, rises $\sim 4 \mathrm{~km}$ from the ocean floor, and reaches $823 \mathrm{~m}$ above sea level, with a surface area of $\sim 122 \mathrm{~km}^{2}$ (Baker, 1969). Together with the Bonaparte seamount, it forms a volcanic chain attributed to traditional hot-spot theory (Chaffey et al., 1989). Geochemically, the island comprises a single alkaline suite which extends from highly porphyritic alkali basalts to mildly peralkaline trachytes and phonolites (Figure 3I). This suite is biased volumetrically toward its mafic end, with basalts constituting $70-80$ vol. $\%$ of the subaerial portion of the island, whilst trachybasalts represent 15-25 vol. \%, trachyandesites 4 vol. \%, and evolved felsic rocks only 1 vol. \% (Baker, 1968, 1969). The alkali basalts contain primarily phenocrysts of clinopyroxene and olivine, with plagioclase becoming more significant in the trachybasalts and trachyandesites. The trachytes contain olivine and Timagnetite phenocrysts, with alkali feldspar, plagioclase, Timagnetite, and aegirine-augite in the groundmass, whereas the phonolites and phonolitic trachytes contain alkali feldspar as the dominant phenocryst phase, and a combination of alkali feldspar, aegirine-augite, Ti-magnetite, nepheline, aegirine, and aenigmatite in the groundmass (Baker, 1969; Kawabata et al., 2011).

There are two volcanic centers: an older, volumetrically less significant shield volcano which forms the NE of the island, and a younger, more complex shield volcano which forms the SW of the island. Both comprise predominantly basaltic lava flows and scoria cones extruded from centralized fissural systems. The older volcanic center is dated (by whole-rock ${ }^{40} \mathrm{~K}-{ }^{40} \mathrm{Ar}$ ) at 14.3-11.4 Ma (Baker et al., 1967; Chaffey et al., 1989; Figure 2), and comprises a thick (up to $\sim 400 \mathrm{~m}$ ) sequence of altered mafic breccias, presumed to be of submarine origin, overlain by $\sim 800 \mathrm{~m}$ of interbedded basaltic lavas and pyroclastic deposits (Baker, 1969). At around 11.4 Ma, volcanism shifted to the SW, generating a complex series of mafic lavas and pyroclastic deposits with three unconformities, over the course of $\sim 3$ m.y. (11.3-8.4 Ma; Baker, 1969; Chaffey et al., 1989). This activity was recognized to be cyclic in nature by Baker (1969), with individual cycles comprising effusive, then explosive activity, followed by a period of erosion. At around 7.6 Ma, approximately 1 m.y. after the cessation of volcanism, the SW center was intruded by a number of dykes and parasitic masses, ranging in composition from phonolites and trachytes, to trachyandesites and trachybasalts (Baker, 1969).

\section{Trindade}

The island of Trindade is situated approximately $1,140 \mathrm{~km}$ east of the Brazilian coast, and rises some $5 \mathrm{~km}$ from the surrounding ocean floor. Together with the nearby islet group of Martin Vaz, Trindade lies at the end of the Vitória-Trindade ridge, an E-W trending alignment of seamounts believed to represent the volcanic trail of the underlying Trindade mantle plume (e.g.,
Crough et al., 1980; O'Connor and Duncan, 1990; Thompson et al., 1998). Trindade itself has a surface area of $6 \mathrm{~km}^{2}$, and represents a deeply eroded remnant of a once larger volcanic edifice.

The stratigraphy of Trindade was established by Almeida (1961), who provided a geological map (Almeida, 1963) and identified five distinct volcanic episodes in the islands history, ${ }^{40} \mathrm{~K}-{ }^{40} \mathrm{Ar}$ dated from 3.6 Ma to present by Cordani (1970; Figure 2). More recently, the stratigraphy and determined ages have been revised by Pires and Bongiolo (2016) and Pires et al. (2016), respectively. The Trindade Complex (3.22-2.78 $\mathrm{Ma}$ ) comprises a $500 \mathrm{~m}$ thick succession of nephelinitic to phonolitic pyroclastic deposits, cross-cut by various sills and dykes of nephelinitic, basanitic, and lamprophyric compositions, as well as necks and associated radial dykes of phonolitic composition (Figure 3J). The Desejado Formation (2.6-1.5 Ma) overlies the Trindade Complex uncomformably, comprising an $\sim 300 \mathrm{~m}$ thick succession of effusive and pyroclastic phonolitic nephelinites, olivine-poor nephelinites, and phonolites. The remaining three formations (the Morro Vermelho Formation, the Valado Formation, and the Paredão Formation, in order of decreasing age) comprise pyroclastic and effusive sequences of exclusively nephelinitic composition and variable thicknesses ( $\sim 250, \sim 60$, and $\sim 250 \mathrm{~m}$, respectively). An ${ }^{40} \mathrm{Ar} /{ }^{39} \mathrm{Ar}$ age of $254 \pm 198 \mathrm{ka}$ was produced for an olivine-rich nephelinitic lava from the Paredão Formation, marking the youngest volcanic activity on the island (Pires et al., 2016). The stratigraphy of Martin Vaz is essentially unknown, although compositions including biotite-bearing nephelinite (ankaratrite), basanite, and peralkaline phonolite have been reported (Mitchell-Thomé, 1970; Marques et al., 1999; Siebel et al., 2000), and a ${ }^{40} \mathrm{~K}-{ }^{40} \mathrm{Ar}$ age of $<0.7$ Ma was produced by Cordani (1970).

In terms of the overall evolution of the island, the older Trindade Complex is considered to represent an old, eroded volcanic edifice with a bimodal character, which experienced four magmatic pulses following a pronounced period of erosion. The occurrence of evolved, peralkaline rocks appears to have been restricted to the older portion of the island's history (the Trindade Complex and the Desejado Formation; 3.22-1.5 Ma) (Marques et al., 1999). The younger eruptive products are exclusively ultramafic, although two end-members are identified on the basis of mineral and whole-rock compositions, with the rocks of the youngest formation (Paredão Formation) representing a mixture of the two (Marques et al., 1999). The phonolitic rocks of Trindade are characterized petrographically by phenocrystic alkali feldspar and feldspathoids, with lesser clinopyroxene. The various ultramafic and mafic rocks typically exhibit much more diverse mineral contents, including phenocrystic olivine, nepheline, leucite, perovskite, clinopyroxene, and biotite, although their respective proportions vary considerably (Marques et al., 1999).

\section{Tristan da Cunha}

The Tristan da Cunha island group comprises three separate islands (Tristan da Cunha, Inaccessible, and the Nightingale Group) and various islets, located in the South Atlantic Ocean, approximately $400 \mathrm{~km}$ east of the Mid-Atlantic Ridge (Baker 
et al., 1964). All three of the islands represent the peaks of volcanic cones which rise abruptly from the sea floor, some $3.5 \mathrm{~km}$ below (Heezen and Tharp, 1961). Tristan da Cunha (referred to hereafter as Tristan) comprises a near-perfect cone, whereas both Inaccessible and Nightingale have substantial shallow water platforms, suggesting considerable erosion of once larger edifices (Gass, 1967). The island of Tristan rises to 2,062 $\mathrm{m}$ above sea level, with a surface area of $\sim 100 \mathrm{~km}^{2}$ and a circular shape. A single primary vent is located at the center of the island, with more than 30 parasitic vents and numerous radial dykes located on the flanks (Le Roex et al., 1990). Based upon its youthful morphology and a number of available ${ }^{40} \mathrm{~K}-{ }^{40} \mathrm{Ar}$ ages, the subaerial portion of the main shield-building phase of the island is considered to have occurred between 0.2 and $0.1 \mathrm{Ma}$, with continued activity until the present day (McDougall and Ollier, 1982; Hicks et al., 2012; Figure 2). The most recent eruptive activity occurred in 1961, and around 1700 AD (Le Roex et al., 1990). The majority of the exposed eruptive products are variably porphyritic, silica undersaturated basanites ( 80\%) (Figure 3K). Intermediate compositions (phonotephrites) account for $\sim 15 \%$ of the exposed rocks, and are similarly variable in crystal content. The most evolved compositions (tephriphonolites), restricted to only $\sim 5 \%$ of the exposed stratigraphy, are described as aphyric to porphyritic, with phenocrysts of kaersutitic amphibole, Timagnetite, plagioclase, clinopyroxene, sphene, and apatite (Le Roex et al., 1990).

Inaccessible Island has a surface area of $\sim 14 \mathrm{~km}^{2}$ and is surrounded by a shallow $(\sim 200 \mathrm{~m})$ submarine platform, suggesting that it represents the erosional remnant of a larger volcanic cone that was once $\sim 16 \mathrm{~km}$ in diameter, making it somewhat larger than Tristan's current edifice (Baker et al., 1964). A ${ }^{40} \mathrm{~K}-{ }^{40} \mathrm{Ar}$ age provided by Gass (1967) suggests that subaerial volcanism began at around $3 \mathrm{Ma}$ (Figure 2), with the island subsequently achieving its maximum size and then being subjected to 90-95 vol. \% erosion to reach its current form. Available geochemical data for Inaccessible Island indicate a somewhat less alkaline trend than seen on Tristan, ranging from alkali basalts (found as thin lava flows and cinder cones) to trachytes and phonolites (Cliff et al., 1991).

The Nightingale Group comprises three separate islands (Nightingale, Middle, and Stoltenhoff), with a combined surface area of $\sim 3 \mathrm{~km}^{2}$. As for Inaccessible Island, there is substantial evidence to suggest that the islands are the heavily-eroded remnant of a single large volcanic cone (Gass, 1967). Two prominent lithologies are described; yellow ashes and agglomerates which dominate the lower portions of the islands, and massive units of porphyritic trachytes which form the upper portions (Baker et al., 1964). The former rocks are named collectively the Older Pyroclastic Sequence (Baker et al., 1964), and were subsequently intruded, initially by trachybasalts, followed by trachytic plugs which also formed lava flows (Gass, 1967). These are overlain by a localized trachytic flow and an extensive yellow pyroclastic unit which bear no intrusive lithologies, named the Younger Pyroclastic Group (Baker et al., 1964). Gass (1967) provided ${ }^{40} \mathrm{~K}-{ }^{40} \mathrm{Ar}$ dates which constrain the Older Pyroclastic Sequence to more than $18 \mathrm{Ma}$, suggesting that the Nightingale Group represents volcanism considerably older than either Inaccessible or Tristan (Figure 2). Compositionally, the rocks of the Nightingale Group have a more limited span than observed on the other two islands, ranging from trachybasalts to trachyte (Baker et al., 1964; Gass, 1967; Mitchell-Thomé, 1970). Basaltic compositions are notably absent from the stratigraphy.

\section{Gough Island}

Gough Island lies in the southernmost Atlantic Ocean, $\sim 550 \mathrm{~km}$ east of the Mid-Atlantic Ridge, and $400 \mathrm{~km}$ south east of the Tristan da Cunha archipelago. The $13 \times 7 \mathrm{~km}$-wide island has a surface area of $\sim 67 \mathrm{~km}^{2}$ and rises from a depth of $\sim$ $3.5 \mathrm{~km}$ to $\sim 910 \mathrm{~m}$ above sea level, overlying $\sim 38$-millionyear old (magnetic anomaly 13) oceanic crust of the African plate (Maund et al., 1988). The island is rugged and deeply dissected in nature, implying that erosion outpaces volcanic activity (Campbell, 1914). The rocks of Gough Island form a single, continuous, silica-undersaturated series from picrite basalt to aegirine-augite trachyte (Zielinski and Frey, 1970; Le Roex, 1985; Figure 3L), and are described in considerable detail by Le Maitre (1962). The picritic rocks are highly porphyritic with large phenocrysts of olivine and often strongly zoned clinopyroxene. By contrast, the felsic rocks are often phenocryst-poor, and contain phenocrysts and glomerocrysts of both plagioclase and alkali feldspar, alongside lesser biotite, fayalitic olivine, Timagnetite, apatite, clinopyroxene, and rare sodalite (Le Roex, 1985). Overall, felsic rocks are dominant in volume, occurring as thick lava flows and domes, pyroclastic deposits, and intrusive lithologies (Maund et al., 1988).

The stratigraphy of the island was first studied in detail by Le Maitre (1962), and subsequently revised by Maund et al. (1988). The latter authors utilized a number of ${ }^{40} \mathrm{~K}-{ }^{40} \mathrm{Ar}$ ages to define an 'Older Basalt Group' (2.55-0.5 Ma) (Figure 2), followed by an erosive period of $\sim 0.3 \mathrm{~m}$.y., followed by the 'Trachyte Extrusives' ( $\sim 0.2 \mathrm{Ma}$ ) and the 'Edinburgh Peak Basalts' $(\sim 0.1 \mathrm{Ma})$. A number of aegirine-augite trachyte plugs are also described, intruded into the youngest rocks of the Older Basalt Group. Although Le Maitre (1962) linked these intrusive lithologies with the Trachyte Extrusives, the ${ }^{40} \mathrm{~K}-{ }^{40} \mathrm{Ar}$ ages of Maund et al. (1988) suggest that they instead represent a period of felsic magmatism that is temporally distinct, being separated from the Trachyte Extrusives by $\sim 0.3$ m.y. Overall, the history of the island can be divided into four key phases: (1) a basalt shield-building phase comprising basaltic hyaloclastites, pillow lavas, and lava flows, most likely from a single central vent, (2) A minor phase of peralkaline trachyte intrusions into the basaltic lavas, followed by a period of erosion, (3) a substantial phase of trachytic activity, erupted from a variety of vents and exhibiting a range of eruptive behavior, and (4) a minor phase of renewed basaltic activity, leading to the generation of a cinder cone complex (Maund et al., 1988).

\section{Bouvet Island (Bouvetøya)}

Bouvet Island (or Bouvetøya) is found in the southernmost Atlantic Ocean, close to the triple junction on the South Atlantic Ridge. The island has an above-sea-level volume of $\sim 25 \mathrm{~km}^{3}$, and a surface area of $55 \mathrm{~km}^{2}$, and rests upon oceanic crust $\sim 6 \mathrm{Ma}$ in age (Imsland et al., 1977). Magmatism in the 
region has been linked to the presence of a mantle plume (the Bouvet mantle plume; Morgan, 1972; Le Roex et al., 1985). No detailed geological map has been made for Bouvet Island due a substantial ice cap, which covers $95 \%$ of the islands surface. Instead, current knowledge relating to the volcanic evolution of the island is based upon limited exposure found at the island's margins. The age of the subaerial portion of the island is believed to be $<0.7 \mathrm{Ma}$ (Verwoerd, 1972) or $<1.4 \mathrm{Ma}$ (Prestvik et al., 1999; Figure 2). The primary eruptive center is in the NW of the island, where active fumaroles occur and where an $~$ $4 \mathrm{~km}$ wide topographic depression is believed to be a caldera (Imsland et al., 1977). The most recent volcanic activity may have occurred between 1955 and 1957, when a small platform formed on the western coast (Baker and Tomblin, 1964; Lunde, 1965).

The rocks of Bouvet Island belong to a single, sodic, silicaoversaturated series, which includes alkali basalts, hawaiites, mugearites, benmoreites, and mildly peralkaline trachytes and rhyolites (Verwoerd et al., 1976; Prestvik, 1982; Figure 3M). The mafic rocks contain Ca-rich plagioclase megacrysts and glomerocrysts, alongside less common olivine and clinopyroxene. Similarly, the intermediate rocks contain megacrysts and glomerocrysts, though they are more diverse, including $\mathrm{Na}$ rich plagioclase, clinopyroxene, olivine, Ti-magnetite, and apatite (Imsland et al., 1977). By contrast, the felsic rocks are dominated by alkali feldspar, which exists as phenocrysts, microphenocrysts, and groundmass crystals. Olivine, clinopyroxene (including aegirine-augite), and $\mathrm{Na}$-amphibole are found in small quantities as microphenocrysts or as groundmass microlites. Quartz is also rarely found in the groundmass, where it occurs alongside Na-amphibole near to vesicles (Imsland et al., 1977).

\section{CHARACTERIZING THE MAGMATIC SYSTEMS: PETROGENESIS AND PRE-ERUPTIVE CONDITIONS}

In this section, we apply the combined dataset gathered by this study to key topics associated with the petrogenesis of peralkaline felsic magmas within the magmatic systems of the Atlantic Ocean islands. This includes primarily compiled published datasets, but also a lesser amount of original data derived from this study, specifically pre-eruptive temperature, $\mathrm{H}_{2} \mathrm{O}_{\text {melt }}$, and melt viscosity estimates. Using this combined dataset, we evaluate firstly the role of fractional crystallization, crustal assimilation, and magma mixing in the formation of peralkaline felsic magmas. Second, we investigate the pre-eruptive $\mathrm{P}-\mathrm{T}-\mathrm{fO}_{2}-\mathrm{H}_{2} \mathrm{O}_{\text {melt }}$ conditions of the erupted peralkaline felsic magmas, applying available estimates from published studies, as well as new data derived from the application of thermo-hygrometrical models. We then go on to construct an integrated model for the physical and chemical configuration of the magma reservoirs from which the peralkaline felsic magmas are derived, and to develop an original, large-scale, schematic model which can account for the development of peralkaline felsic magmas in ocean island magmatic systems.

\section{Petrogenesis of Atlantic Ocean Island Peralkaline Magmas}

\section{Fractional Crystallization}

The majority of the peralkaline magmatic systems of the Atlantic Ocean are controlled primarily by fractional crystallization of mantle-derived, mafic magmas, with a significant portion of the fractionation history frequently taking place under shallow crustal conditions (e.g., Beier et al., 2006; Andújar et al., 2010; Sliwinski et al., 2015). This process not only controls the generation of peralkaline felsic magmas from basaltic progenitors, but also controls evolutionary trends within peralkaline felsic magmas, forming felsic magmas with varying degrees of peralkalinity. There exists a wide range of published studies and quantitative models which reliably recreate the compositions observed in the magmatic systems of the Atlantic, including major element, least-squares mass balance models, thermodynamic models, and trace element models (e.g., Iceland: Carmichael, 1964; Macdonald et al., 1990; Furman et al., 1992a; Sigmarsson et al., 1992; Hards et al., 2000; Prestvik et al., 2001; Martin and Sigmarsson, 2007; Azores: Widom et al., 1992; Mungall and Martin, 1995; Renzulli and Santi, 2000; Beier et al., 2006; Larrea et al., 2013, 2014a; Zanon et al., 2013; Zanon, 2015; Jeffery et al., 2016b, 2017; Canary islands: Freundt and Schmincke, 1995; Ablay et al., 1998; Neumann et al., 1999; Sliwinski et al., 2015; Tornare et al., 2016; Cape Verde: Holm et al., 2006; Kogarko, 2008; Hildner et al., 2011; Cameroon Line: Marzoli et al., 2000; Ascension Island: Harris, 1983; Kar et al., 1998; Chamberlain et al., 2016; Bouvet Island: Le Roex and Erlank, 1982; Prestvik et al., 1999; Tristan da Cunha: Le Roex et al., 1990; Harris et al., 2000; Gough Island: Le Roex, 1985; Harris et al., 2000; St. Helena: Baker, 1969; Fernando de Noronha: Weaver, 1990; Lopes and Ulbrich, 2015; Trindade: Weaver, 1990; Bongiolo et al., 2015). These are frequently supported by geochemical indicators of extensive fractionation, such as the depletion of $\mathrm{Sr}, \mathrm{Ba}, \mathrm{Ti}$, and $\mathrm{P}$, the formation of negative $\mathrm{Eu}$ anomalies, and the enrichment of incompatible trace elements such as $\mathrm{Zr}, \mathrm{Nb}, \mathrm{Rb}$, and the REE (Figures 4-6). These features are frequent, but not ubiquitous, amongst the peralkaline rocks of the Atlantic Ocean. For example, negative Eu anomalies are not seen in the peralkaline rocks of Cape Verde, Fernando de Noronha, Trindade, or Tristan da Cunha, and are most pronounced in the rocks of Iceland, the Azores, and Ascension (Figure 5). This may show some correlation with the degree of silica-saturation in the erupted magmas, with the Si-oversaturated suites exhibiting the most pronounced anomalies. However, the Si-undersaturated rocks of St. Helena appear to contradict this, exhibiting a weakly developed negative Eu-anomaly. Furthermore, the pronounced troughs observed in Figure 6 for Ba, Sr, P, and Ti are markedly less clear, or altogether absent from the peralkaline rocks of Trindade, suggesting the potential for a more complex petrogenetic regime.

Where determined, the total degree of fractionation in each case is considerable, ranging from $\sim 60 \%$ from parental OIB for felsic compositions transitional between metaluminous and mildly peralkaline, and in excess of $90 \%$ for the most extreme peralkaline compositions. For example, the strongly peralkaline $(\mathrm{PI}=1.92-4.95)$ interstitial glass found within syenitic ejecta 


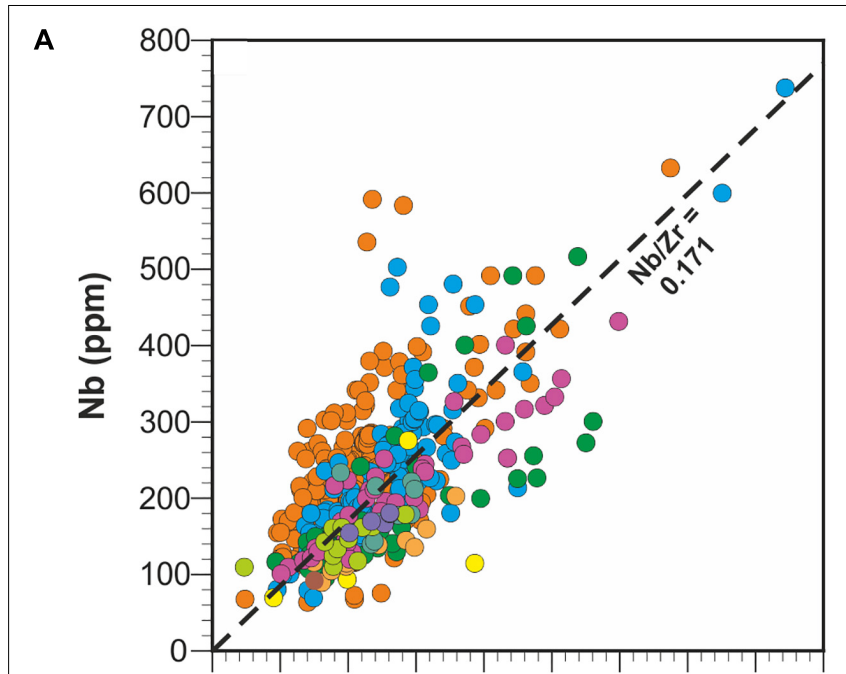

B

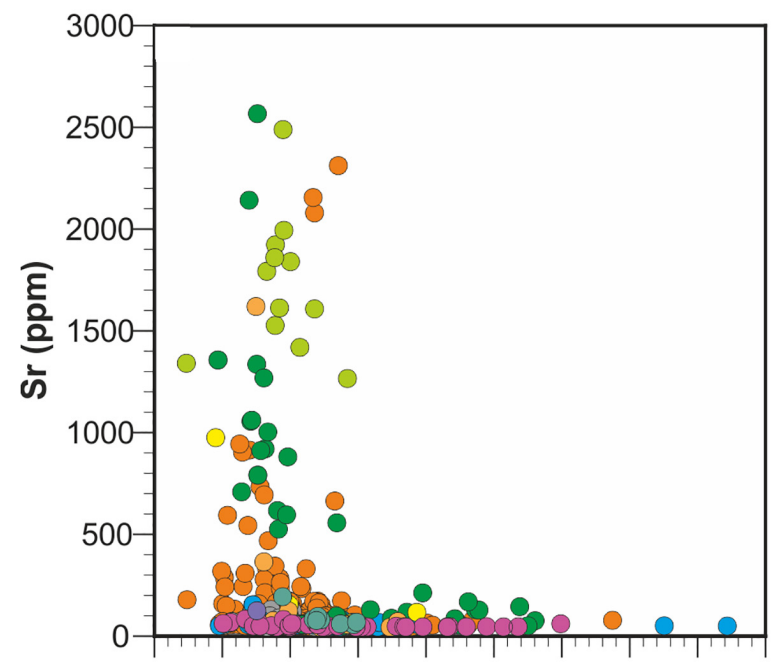

C

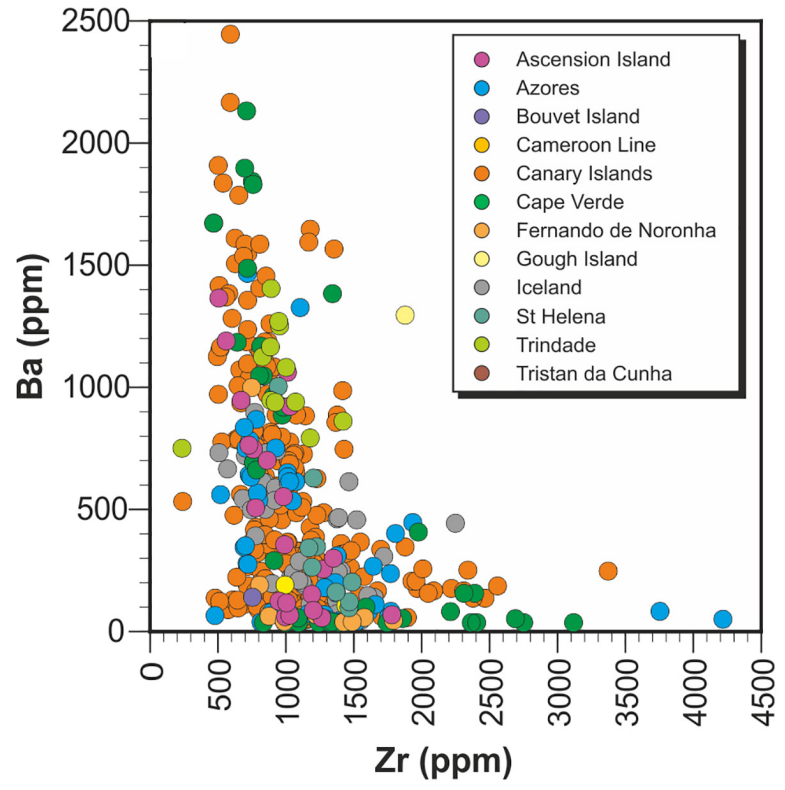

FIGURE 4 | Continued
FIGURE 4 | Bivariate plots showing published data for selected trace elements in peralkaline felsic rocks from across the Atlantic Ocean. In each plot, $Z r$ is used as I fractionation index, with the highest $Z r$ values assumed to reflect the most evolved compositions (A) Nb-Zr plot highlighting the general adherence of the data to the typical $\mathrm{Nb} / \mathrm{Zr}$ ratio for $\mathrm{OIB}$, which is shown as a dashed line (Sun and McDonough, 1989), (B) Sr-Zr plot highlighting 'enriched' Sr values at low Zr contents, and (C) Ba-Zr plot showing rapidly decreasing Ba trend with increasing $\mathrm{Zr}$ contents.

from Terceira, Azores is argued to represent the residual liquid from extreme fractionation, undoubtedly in excess of 95\% from the original parental basalts (Mungall, 1993). The same author utilizes textural evidence to note that, in this instance, the glasses do not represent partial melting, as observed on Ascension (Harris and Bell, 1982). These high degrees of fractionation may effectively rule out single-stage evolutionary models due to the inherent difficulty in separating a 5\% residual melt from an effectively 'locked' crystal mush (Dufek and Bachmann, 2010). As such, the volume of residual crystalline material which is contributed to the crust is debatable, and strongly influenced by the precise mechanisms of crystal-melt segregation during fractional crystallization, as well as the temporal extent of felsic peralkaline magmatism, and the potential for 'cannibalization' and recycling of such material (see below; e.g., Wiesmaier et al., 2013). Although it is logical that the volume of residual crystalline material increases with continued magmatism, the application of a more rheologically viable two-stage crystal mush extraction model may drastically reduce the volume of residual material for a given volume of fractionating magma, and therefore reduce the rate of accumulation of fusable crystal mush in the crust ( $c f$. Sliwinski et al., 2015). For example, a single stage fractionation model applied to an erupted volume of $10 \mathrm{~km}^{3}$ implies $90 \mathrm{~km}^{3}$ of residual material has been added to the crust (assuming 90\% total fractionation). By contrast, a two-stage fractionation model, with each stage assuming $60 \%$ fractionation, achieves a similar degree of fractionation in the erupted material but yields only $52.5 \mathrm{~km}^{3}$ of residual material. As such, the volumetric ratio of residual to erupted material may be lower than implied by high degrees of fractionation, and the actual mechanisms of crystalmelt segregation may therefore impact significantly upon the viability of other magmatic processes, such as the partial melting of residual lithologies.

The results of various fractional crystallization models, as well as the predominance of alkali feldspar within the peralkaline rocks themselves, indicate that the final portion of the liquid line of descent, both in the Atlantic systems and globally, is characterized by alkali feldspar crystallization, which acts to drive the melt toward more peralkaline compositions (Bailey and Schairer, 1964; Thompson and MacKenzie, 1967; Nicholls and Carmichael, 1969). Additional phases which are common in small quantities and which play a secondary (and increasingly important as differentiation continues) role during the differentiation of peralkaline felsic melts include fayalitic olivine, clinopyroxene (which may be augitie or aegirine/aegirine-augite), Ti-magnetite, ilmenite, sodic plagioclase, kaersutite, apatite, biotite, feldspathoid group 

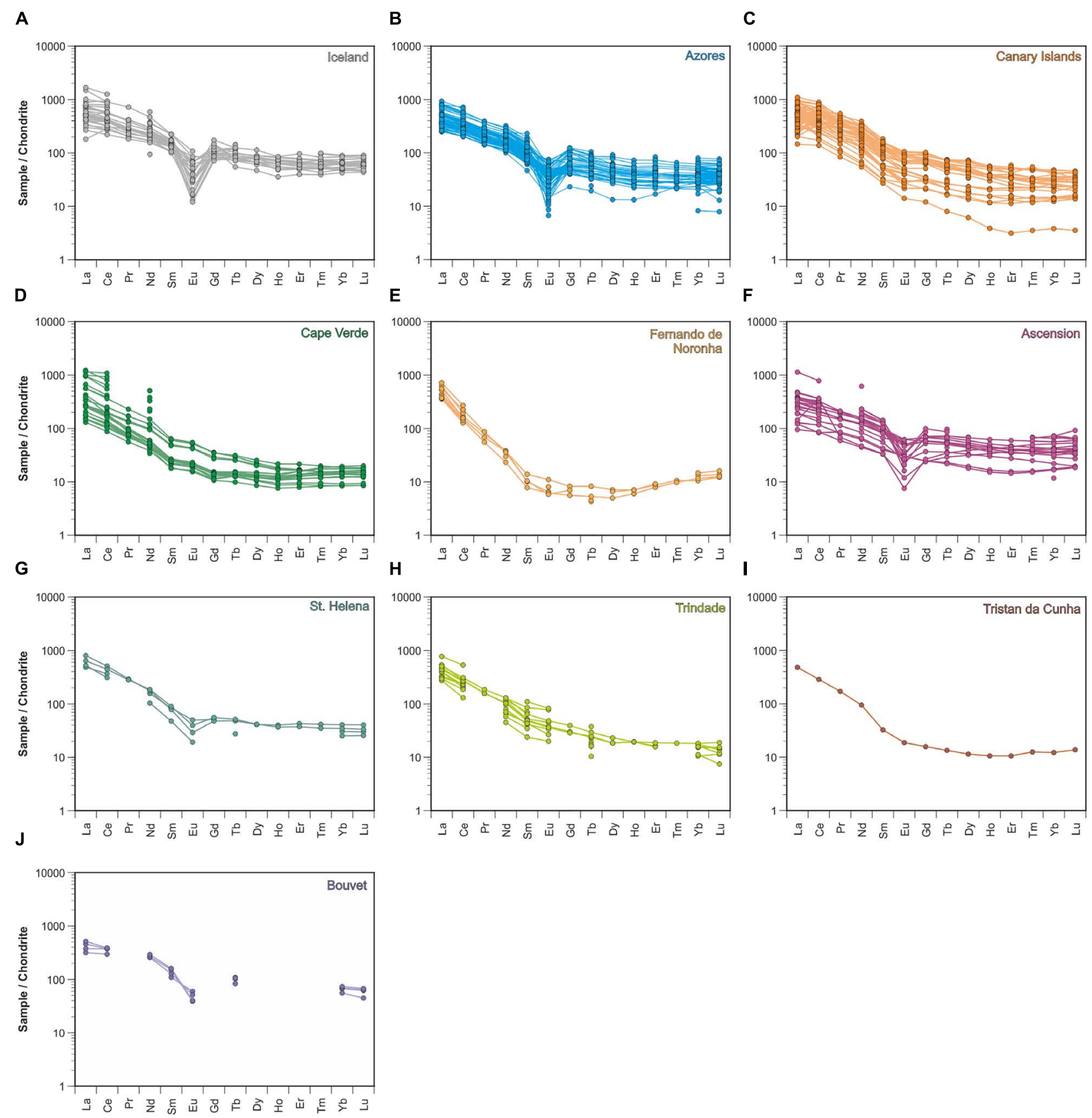

FIGURE 5 | Published chondrite-normalized (Sun and McDonough, 1989) REE profiles for (A) Iceland, (B) the Azores, (C) the Canary Islands, (D) Cape Verde, (E) Fernando de Noronha, (F) Ascension, (G) St. Helena, (H) Trindade, (I) Tristan da Cunha, and (J) Bouvet.

minerals, aenigmatite, and Na-amphiboles (e.g., Ablay et al., 1998; Kar et al., 1998; Scaillet and Macdonald, 2001; Kogarko, 2008; Macdonald et al., 2011; Zanon, 2015). The onset of peralkalinity may occur at highly variable melt $\mathrm{SiO}_{2}$ contents (Figure 3), and is favored by low pressure conditions (Bailey, 1974). Thus, the development of a shallow crustal reservoir in which magmas can evolve via fractional crystallization is paramount to the development of peralkaline magmatism. In fact, the transfer of magmas from lower crustal or mantle depths into a shallow crustal reservoir, a process invoked at many Atlantic Ocean island systems (see below), may initiate plagioclase fractionation, acting as the trigger for the development of peralkaline magmas.

\section{Crustal Assimilation and Partial Melting}

Although seemingly of second order importance when compared to fractional crystallization, the role of crustal assimilation has also been recognized in various Atlantic magmatic systems (e.g., 


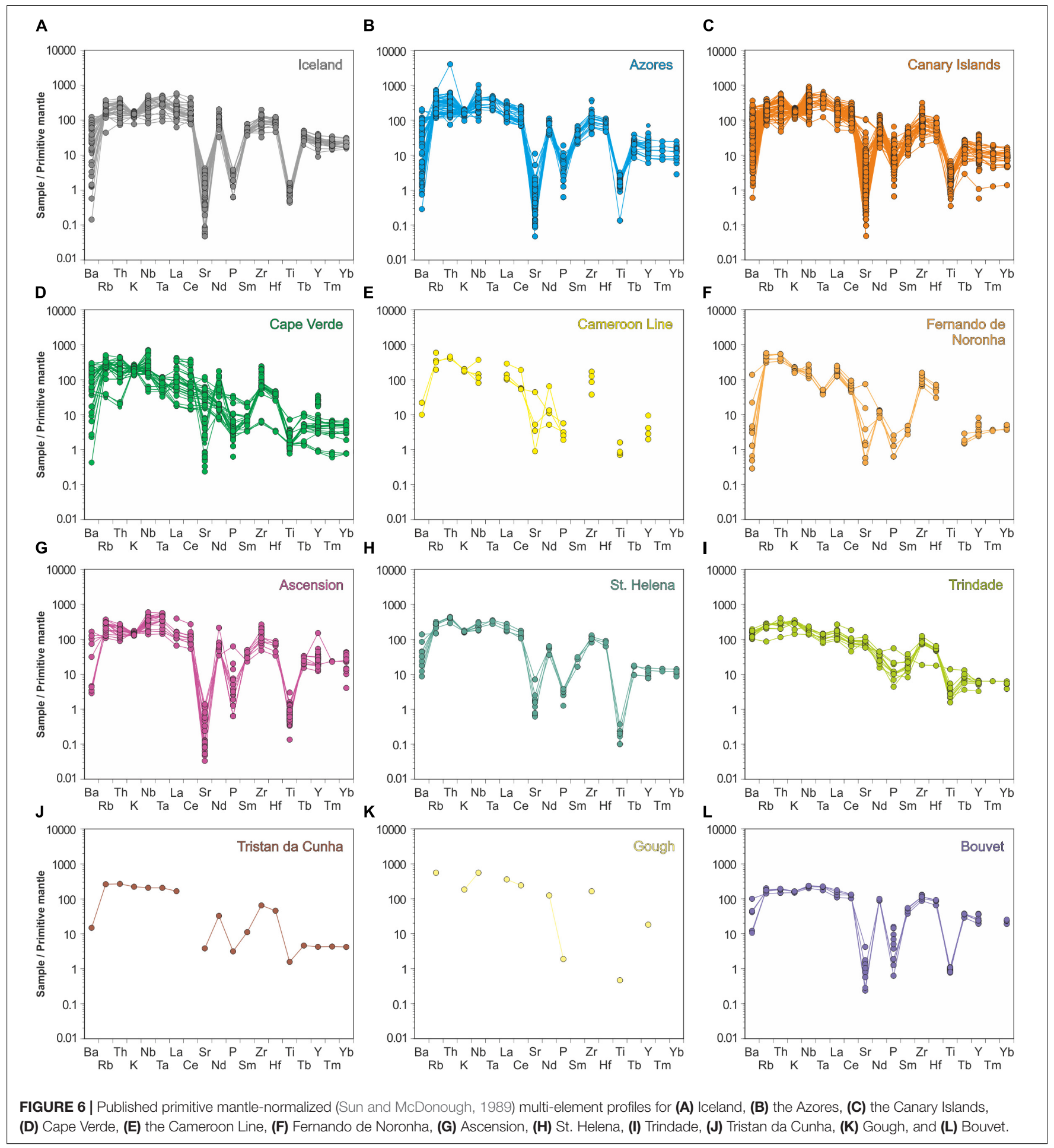

Azores: Nielsen et al., 2007; Genske et al., 2013; Madeira: Widom et al., 1999; Canary Islands: Thirlwall et al., 1997; Widom et al., 1999; Troll and Schmincke, 2002; Hansteen and Troll, 2003; Cape Verde: Jørgensen and Holm, 2002; Doucelance et al., 2003; Ascension: Harris et al., 1982; Weis et al., 1987; Kar et al., 1998; Tristan da Cunha: Harris et al., 2000). Crustal assimilation may occur at any point within the system, and may therefore involve the assimilation of hydrothermally altered oceanic crust (e.g., Doucelance et al., 2003; Genske et al., 2013, marine sediments (e.g., Thirlwall et al., 1997; Widom et al., 1999), or previously intruded lithologies and crystal mush (e.g., Harris and Bell, 1982; Jørgensen and Holm, 2002). Nevertheless, there remain examples where crustal contamination has been essentially ruled out or merely inferred as a possibility (e.g., 
Canary Islands: Hoernle, 1998; Cameroon Line (Oceanic Sector): Déruelle et al., 2007; Bouvet Island: Imsland et al., 1977; Gough Island: Harris et al., 2000; Trindade: Siebel et al., 2000), although in some cases this may simply reflect the comparative lack of data for some of the Atlantic islands. Considering the inevitable accumulation of felsic crystalline residues in the upper crust during the establishment and development of a stable peralkaline magma reservoir, it follows that felsic lithologies must represent an increasingly viable and important contaminant during the peralkaline stage of magma evolution. These may take the form of accumulated crystal mush or solidified intrusive bodies of peralkaline felsic magma. Direct evidence for this process has been identified on Ascension, where glass-bearing syenitic inclusions in a trachyandesitic lava flow are interpreted to reflect partial melting of subvolcanic intrusive lithologies (Harris and Bell, 1982). Further evidence exists on São Miguel, Azores, where Snyder et al. (2004) identified the contamination of peralkaline trachytes with seawater-altered syenites, and in the Canary Islands, where recycling of subvolcanic differentiated rocks has been proposed on Tenerife (Ablay et al., 1998; Wolff et al., 2000; Sliwinski et al., 2015; Turner et al., 2017). This may be exemplified by the increase in ${ }^{87} \mathrm{Sr} /{ }^{86} \mathrm{Sr}$ values (and potential decoupling of $\mathrm{Sr}$ and $\mathrm{Nd}$ isotopic values) observed in the felsic rocks of the Azores, the Canary Islands, and Ascension, and possibly Iceland (Figures 3,7 ). In some cases, the melting of subvolcanic felsic rocks is sufficiently advanced that the generated melts can accumulate and be erupted (Wiesmaier et al., 2013), or accumulate into compositionally distinct layers within the magma reservoir (Wolff et al., 2015). Sliwinski et al. (2015) demonstrated that minor discrepancies in their efforts to model evolved melt compositions could be accounted for by recycling authigenic cumulates, effectively adding alkali feldspar back into the melt.

Despite the generally limited role of crustal assimilation in the generation of peralkaline silicic magmas in the Atlantic, Iceland represents a clear example where both fractional crystallization and bulk melting of the crust have led to the formation of peralkaline felsic magmas (Martin and Sigmarsson, 2007). The silicic magmas belonging to Iceland's central rift zone are somewhat unique in the Atlantic because the partial melting of hydrated metabasaltic crust has been invoked as the primary process responsible for their formation (e.g., Sigurdsson, 1977; Nicholson et al., 1991; Sigmarsson et al., 1991; Jónasson, 1994; Bindeman et al., 2012). By contrast, the peralkaline felsic magmas associated with central volcanoes peripheral to the rift are generally considered to be generated by fractional crystallization (e.g., Carmichael, 1964; Macdonald et al., 1990; Furman et al., 1992a; Prestvik et al., 2001; Martin and Sigmarsson, 2007), suggesting that this somewhat unusual occurrence of partial meltderived peralkaline magmas is the result of variation in the local

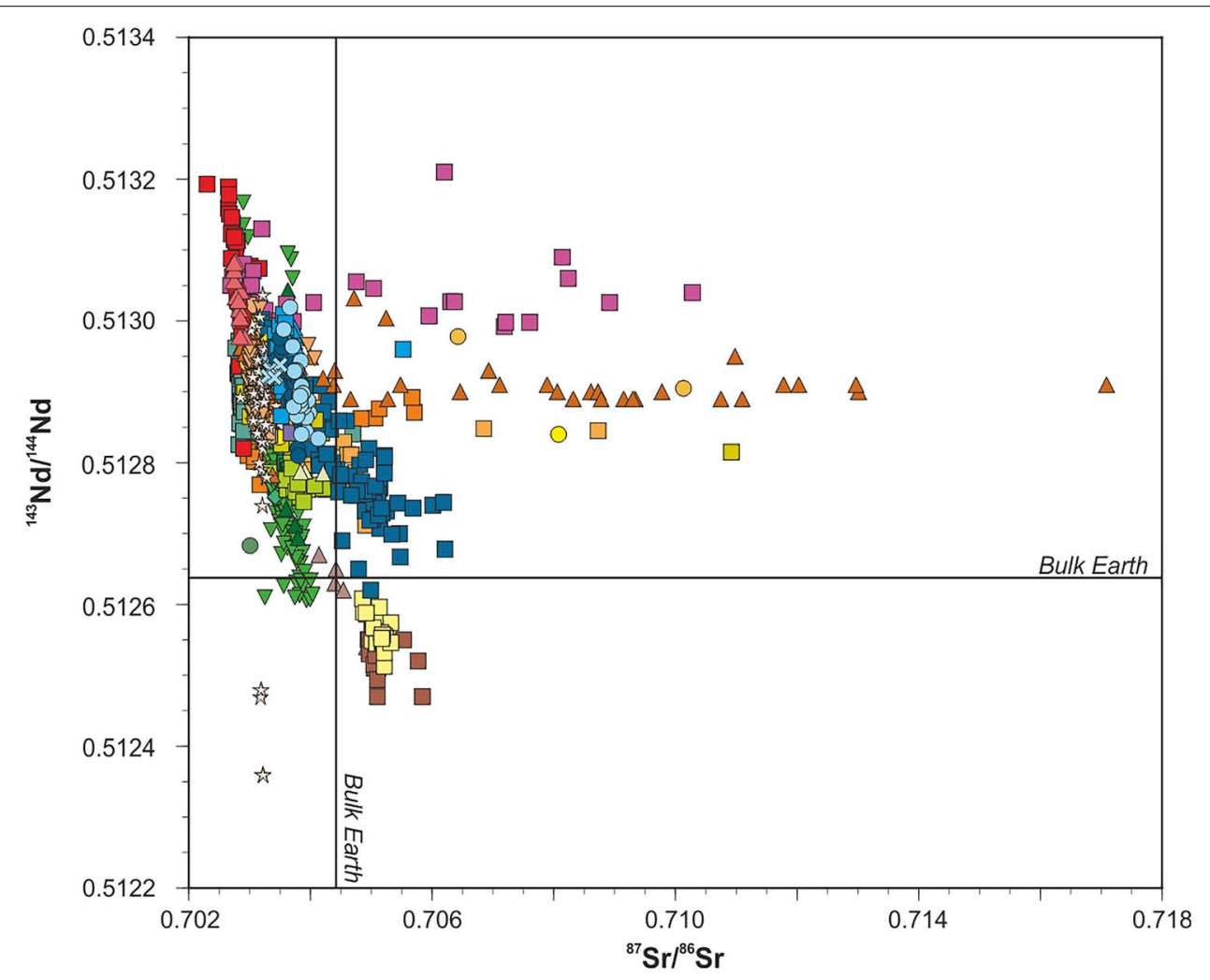

FIGURE 7 | Sr-Nd variation diagram for the magmatic systems of the Atlantic Ocean. All compositions are included, ranging from mafic to felsic. Symbols are as given in Figure 3. For clarity, a single outlier derived from the Fernando de Noronha archipelago is not shown $\left({ }^{87} \mathrm{Sr} /{ }^{86} \mathrm{Sr}=0.73499,{ }^{143} \mathrm{Nd} /{ }^{144} \mathrm{Nd}=0.51284\right.$; Gerlach et al., 1987). 
geothermal gradient, which is strongly influenced by the rift and the underlying mantle plume (Martin and Sigmarsson, 2007, 2010). Nevertheless, this model is not without exception (e.g., Askja volcano; Sigurdsson and Sparks, 1981; Macdonald et al., 1987; Kuritani et al., 2011).

\section{Magma Mixing/Mingling}

Although they are not ubiquitous, the occurrence of pre-eruptive magma mixing/mingling processes is well documented for many of the Atlantic Ocean islands (e.g., Iceland: Sparks et al., 1977; McGarvie et al., 1990; Azores: Storey, 1981; Jeffery et al., 2016b, 2017; D’Oriano et al., 2017; Madeira: Klügel and Klein, 2006; Canary Islands: Wolff, 1985; Araña et al., 1994; Edgar et al., 2002; Cape Verde; Holm et al., 2006; Eisele et al., 2016; Ascension: Weaver et al., 1996; Gough Island: Le Roex, 1985; Bouvet Island: Prestvik et al., 1999). These mixing processes are diverse in their end-members, and include direct mixing between mafic and felsic magmas (e.g., Araña et al., 1994; Lopes and Ulbrich, 2015), mixing between felsic magmas (e.g., Troll and Schmincke, 2002; Bryan, 2006; Pimentel et al., 2015), mingling of melt and crystalline mush (i.e., mush remobilisation) (e.g., Weaver et al., 1996; Sliwinski et al., 2015; D’Oriano et al., 2017; Jeffery et al., 2017), and small-scale mixing of partially melted contaminants and volumetrically superior melt (e.g., Harris and Bell, 1982; Turner et al., 2017). In peralkaline magmatic systems other than those of the Atlantic Ocean, the mixing of mafic and felsic magmas is proposed as a process responsible for the formation of intermediate magmas, which are often scarce compared to mafic and felsic compositions (e.g., Pantelleria: Ferla and Meli, 2006; Gioncada and Landi, 2010). The paucity of intermediate magma compositions can be explained in a variety of ways, including the development of a silicic density barrier in the upper portions of a magma reservoir via sidewall crystallization (e.g., Turner and Campbell, 1986), or the high viscosity of crystal-rich intermediates (e.g., Mungall and Martin, 1995). Considering the common but not ubiquitous presence of bimodal magmatism throughout the Atlantic (Baker, 1974, Figure 3), and the recognition of hybridized magmas at a number of Atlantic volcanic centers (e.g., Iceland: Hards et al., 2000; Azores: Storey, 1981; Moore, 1990; Canary Islands: Wiesmaier et al., 2011), it seems likely that magma mixing plays some role in peralkaline magmatic systems throughout the Atlantic Ocean.

In some cases, mixing processes have been recognized on petrographic grounds, either through the identification of relict crystal populations which exhibit clear disequilibrium with their host magma, or through mineralogical evidence such as chemical zonation. This often takes the form of relict mafic phases such as $\mathrm{Mg}$-rich olivine or clinopyroxene within felsic magmas, or relict felsic phases such as biotite in mafic or intermediate magmas (i.e., mafic-felsic mixing; e.g., Schmincke, 1969; Wolff, 1985; Storey et al., 1989; McGarvie et al., 1990; Neumann et al., 1999; Jeffery et al., 2017), or alternatively heavily resorbed feldspars within felsic magmas (i.e., felsic-felsic mixing; e.g., Troll and Schmincke, 2002). Additionally, partially resorbed and/or disaggregated glomerocrysts may be found, which are interpreted to represent portions of a remobilised crystal mush entrained within the erupted melt either during or prior to eruption (e.g., Sliwinski et al., 2015). Bulk rock data also provide evidence for mixing processes, and potentially the remobilisation of crystal mush. For example, the enrichment of elements such as $\mathrm{Sr}$ and $\mathrm{Ba}$ has been utilized to identify mixing between two variably evolved felsic magma (i.e., feldspar assimilation; e.g., Storey et al., 1989). This process may be responsible for the pronounced enrichments of these elements in the less evolved peralkaline magmas (demonstrated here by lower $\mathrm{Zr}$ contents; Figures $4 \mathrm{~B}, \mathrm{C}$ ), which often exceed the maximum limits of fractional crystallization models (e.g., $<1,000 \mathrm{ppm})$.

\section{Pre-eruptive Conditions}

In this section, we summarize available published estimates of pre-eruptive intensive variables representative of the felsic peralkaline magma systems of the Atlantic Ocean. We include magmas of peralkaline affinity within this dataset, as these represent a precursory evolutionary stage immediately prior to the onset of peralkalinity, which are considered to reflect the same conditions as their peralkaline equivalents. In some instances, this genetic link is emphasized by the gradual shift in peralkalinity index from peralkaline affinity to peralkaline within a single eruptive deposit. Where possible, these data are supplemented by newly determined estimates, derived from the application of the alkali feldspar-melt thermometer of Putirka (2008), and the alkali feldspar-melt hygrometer of Mollo et al. (2015) to previously published chemical data. In each case, the $\mathrm{Kd}_{\mathrm{Ab}-\mathrm{Or}}$ equilibrium test proposed by Mollo et al. (2015) was applied, allowing a single suitable liquid composition to be selected for each case. Input pressure values were set at $100 \mathrm{MPa}$, and it was observed that a variation of $0.1 \mathrm{GPa}$ led to a change in temperature of only $0.1^{\circ} \mathrm{C}$, suggesting that the thermometer is not significantly influenced by variations in pressure. The $1 \sigma$ standard error of estimate (SEE) associated with the thermometer is $\pm 23^{\circ} \mathrm{C}$, whereas the SEE associated with the hygrometer is \pm 0.75 wt. \%. These models are particularly valuable in peralkaline systems due to the dominance of alkali feldspars during the later stages of fractionation, and were freshly applied in this study to existing chemical data for the following locations: the Azores (Storey, 1981; Renzulli and Santi, 2000), Canary Islands (Troll and Schmincke, 2002; Rodriguez-Losada and Martinez-Frias, 2004; Bryan, 2006; Jutzeler et al., 2010; Clay et al., 2011), Ascension (Chamberlain et al., 2016), Trindade (Siebel et al., 2000), Gough Island (Le Roex, 1985), and Bouvet Island (Imsland et al., 1977).

\section{Temperature}

Pre-eruptive temperatures for the combined dataset exhibit considerable range, extending from around $1,050^{\circ} \mathrm{C}$ for magmas with peralkaline affinity (e.g., the trachytes of Faial; Pimentel et al., 2015; the phonolites of the Granadilla eruption, Tenerife; Bryan, 2006), to $\sim 700^{\circ} \mathrm{C}$ for mildly to strongly peralkaline magmas (Figure 8). This range extends down to approximately $600^{\circ} \mathrm{C}$ if autolithic peralkaline syenite clasts, considered to 

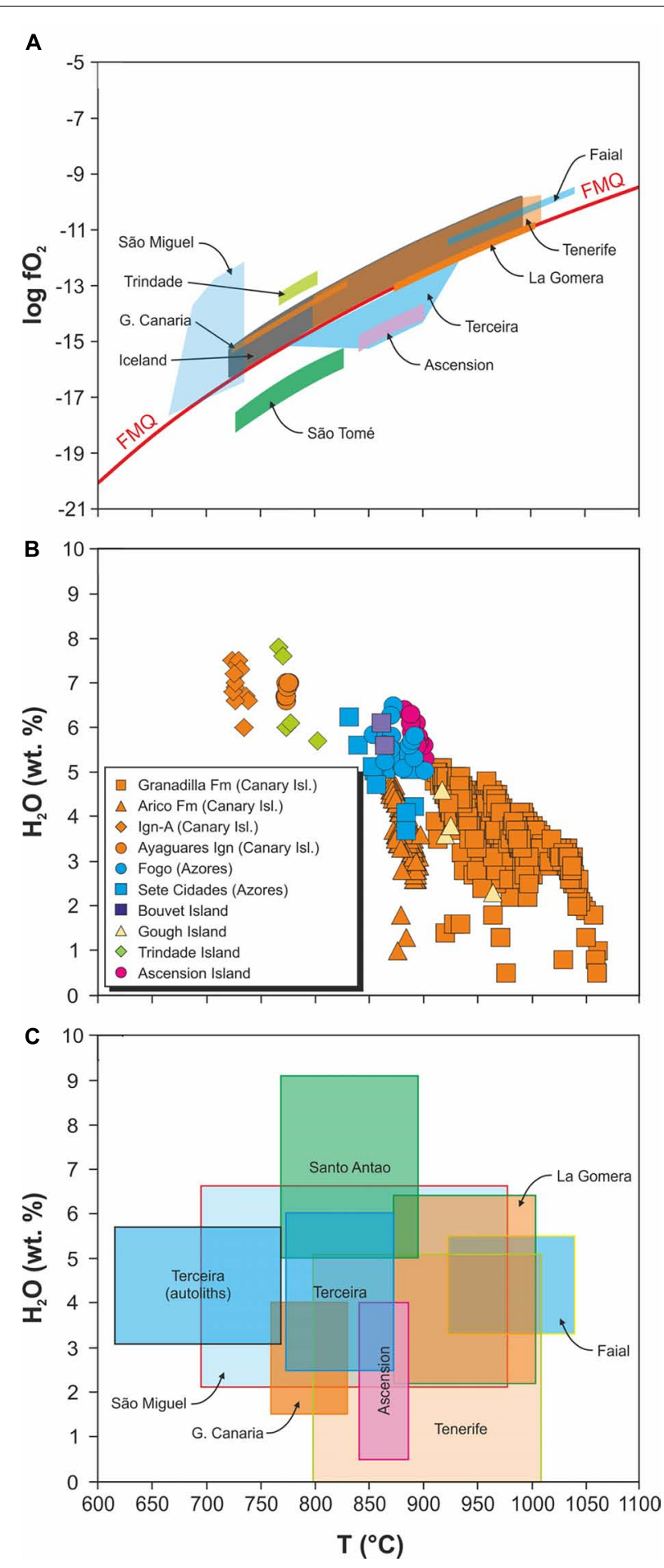

FIGURE 8 | Summarized temperature, $\mathrm{fO}_{2}$, and $\mathrm{H}_{2} \mathrm{O}_{\text {melt }}$ estimates for Atlantic Ocean peralkaline magmas (including those with peralkaline affinity).

(A) Temperature- $\mathrm{fO}_{2}$ estimates derived from published data. (B) Temperature$\mathrm{H}_{2}$ Omelt contents derived via alkali feldspar-melt thermo hygrometry (Putirka, 2008; Mollo et al., 2015), calculated in this study using the data of Imsland et al. (1977), Storey (1981), Le Roex (1985), Renzulli and Santi (2000), Siebel et al. (2000), Troll and Schmincke (2002), Rodriguez-Losada and Martinez-Frias (2004), Clay et al. (2011). (C) Total ranges in temperature and

(Continued)

\section{FIGURE 8 | Continued}

$\mathrm{H}_{2} \mathrm{O}_{\text {melt }}$ based upon published estimates obtained via methods including two-oxide thermometry (Ablay et al., 1998; Troll and Schmincke, 2002; Rodriguez-Losada and Martinez-Frias, 2004; Bryan, 2006; Dávila-Harris et al., 2013; Zanon and Frezzotti, 2013; Pimentel et al., 2015; Chamberlain et al., 2016; Eisele et al., 2016; Jeffery et al., 2016b, 2017).

represent the near-complete solidification of peralkaline magmas, are included (e.g., Jeffery et al., 2017). There is a logical, broad correlation between temperature and peralkalinity, with the most peralkaline magmas recording the coolest temperatures. Temperature estimates derived from two-oxide and other models define considerable ranges for each volcanic island for which there are data. The data derived via alkali feldspar-melt models cluster within the broad range of $1,050-850^{\circ} \mathrm{C}$, and include data from the Azores (Jeffery et al., 2016b, 2017, and calculated using the data of Storey, 1981; Renzulli and Santi, 2000), the Canary Islands (calculated in this study using the data of Troll and Schmincke, 2002; Rodriguez-Losada and MartinezFrias, 2004; Bryan, 2006; Jutzeler et al., 2010; Clay et al., 2011), Bouvet Island (calculated in this study using the data of Imsland et al., 1977), Gough Island (calculated in this study using the data of Le Roex, 1985), and Trindade (calculated in this study using the data of Siebel et al., 2000). Specifically, the estimates from Gran Canaria (Canary Islands), Trindade, and a single ignimbrite formation from Terceira, Azores (GVI, Jeffery et al., 2017), lie at lower values of around $700-850^{\circ} \mathrm{C}$. It is noteworthy that temperature estimates derived from alkali feldspar-melt models appear to record generally higher temperature values than the frequently applied two-oxide models, which likely reflects the comparatively earlier crystallization of alkali feldspar, as well as the rapid re-equilibration timescales of coexisting $\mathrm{Fe}-\mathrm{Ti}$ oxides (e.g., Gardner et al., 1995; Venezky and Rutherford, 1999; Pimentel et al., 2015), meaning that the lower temperatures recorded by $\mathrm{Fe}$-Ti oxide phases reflect the final pre-eruptive magma system and/or syn-eruptive conditions within the plumbing system.

\section{Pressure}

The results of numerous studies have indicated that peralkaline magmas from such classic peralkaline volcanic centers as the East African Rift System and Pantelleria originate from magma storage zones in the shallow crust (e.g., Mahood and Baker, 1986; Avanzinelli et al., 2004; Peccerillo et al., 2007; Macdonald, 2012). Available data for the Atlantic Ocean suggest that the Atlantic island peralkaline magmatic centers are similarly characterized by the presence of a shallow crustal magma storage zone. Preeruptive pressure estimates for peralkaline magmas from the islands of São Miguel and Terceira (Azores), derived from thermodynamic modeling and water solubility constraints, lie between 122 and $156 \mathrm{MPa}$, and 80 and $135 \mathrm{MPa}$, respectively (Beier et al., 2006; Jeffery et al., 2016b, 2017). These values correspond to depths of $\sim 3 \mathrm{~km}$, placing them within the upper crust (crustal thickness $=\sim 15 \mathrm{~km}$; Beier et al., 2006). The peralkaline magmas of Graciosa are also suggested, on the basis of MELTs modeling, to have formed under low pressure conditions (1-3 km; Larrea et al., 2014a). Peralkaline magmas from Gran 
Canaria and Tenerife are estimated via geobarometry to have been stored at pressures between 130 and $270 \mathrm{MPa}$ (Fe-Ti oxide ferrosilite-based barometry; Crisp and Spera, 1987; amphibolebased barometry; Troll and Schmincke, 2002; clinopyroxenemelt barometry; Aulinas et al., 2010), and $150 \mathrm{MPa}$ (water solubility constraints; Ablay et al., 1995; clinopyroxene-melt barometry and fluid inclusion barometry; Klügel et al., 2005; phase equilibrium experiments; Andújar et al., 2008, 2013), respectively. Scarce available pressure estimates derived from QUILF thermobarometry for peralkaline magmatism in the oceanic sector of the Cameroon Line may fall in line with these estimates (e.g., $100 \mathrm{MPa}$; Mbowou et al., 2013). Eisele et al. (2016) utilized clinopyroxene-melt barometry to report somewhat greater values of 200-400 $\mathrm{MPa}$ for the magma reservoirs which produced the partially peralkaline Cão Grande Formation on Santo Antão (Cape Verde), equating to depths of $7-16 \mathrm{~km}$. Similarly, the pre-eruptive conditions of an eruption which produced a prominent fall deposit (with peralkaline affinity) on Ascension Island are estimated via melt inclusion barometry to have been between 216 and $250 \mathrm{MPa}$ (Chamberlain et al., 2016), equating to the lower crust $(\sim 8.5 \mathrm{~km})$. In contrast to the evolved, peralkaline magmas, the mafic magmas from which they are most likely derived typically provide a wide range of pressure estimates, derived via clinopyroxene-melt barometry and fluid inclusion barometry, extending from shallow crustal values to the upper mantle, and often concentrated around the crust-mantle boundary (e.g., Azores: Zanon and Frezzotti, 2013; Zanon et al., 2013, Canary Islands: Hansteen et al., 1998; Klügel et al., 2005; Stroncik et al., 2009, Cape Verde: Hildner et al., 2011, 2012; Mata et al., 2017, Madeira: Schwarz et al., 2004; Klügel and Klein, 2006, Tristan da Cunha: Weit et al., 2017).

Overall, there is a general trend in which the more evolved the magmas become, the shallower their respective magma reservoirs are located. Magma reservoirs that produced peralkaline felsic magmas are generally located within at depths of around 2-4 km. The somewhat less-evolved magmas with peralkaline affinity tend to be stored at deeper depths; for example, the strongly zoned fall deposit on Ascension (PI $=0.55-1.00)$ was stored at lower crustal depths of approximately $8.5 \mathrm{~km}$ (Chamberlain et al., 2016). Similarly, a trachyandesitic lava flow erupted in 1961 on Tristan records depths of 6-10 km (Weit et al., 2017). The Cão Grande Formation of Santo Antão may represent an exception to this, in which two metaluminous to peralkaline magma bodies ( $\mathrm{PI}=0.70-1.12)$ apparently existed at lower crustal levels (7-16 km) (Eisele et al., 2015, 2016). However, these estimates were derived via clinopyroxene-melt barometry, which may record higher pressure values due to the potentially dominant crystallization of clinopyroxene in the lower crust, and its subsequent retention in upper crustal evolved magmas (cf. Klügel et al., 2005; Jeffery et al., 2016b). Furthermore, the errors associated with currently employed clinopyroxenebased barometers are often high (e.g., $\pm 160 \mathrm{MPa}$, Putirka, 2008; $\pm 115 \mathrm{MPa}$, Masotta et al., 2013), limiting their resolution at shallow depths. The described trend is only applicable to the more evolved compositions of each system; mafic magmas are shown to occur at all depths.

\section{Redox Conditions}

The determination of redox conditions in peralkaline magmas is often complicated by the scarcity of rocks in which two coexisting oxide phases are present. Available estimates for Atlantic peralkaline rocks are highly variable, even within individual island systems. Peralkaline ignimbrites on Terceira evolved under relatively reducing conditions, ranging from 1 to 2 log units below the Fayalite-Magnetite-Quartz buffer (FMQ - 1 to FMQ -2; Jeffery et al., 2017), whereas similarly peralkaline rocks from São Miguel yield redox conditions ranging from FMQ +4 to FMQ -2 (Wolff and Storey, 1983; Wolff et al., 1990; Renzulli and Santi, 2000; Jeffery et al., 2016b). The trachytes of Faial with peralkaline affinity record conditions close to FMQ +0.7 (Pimentel et al., 2015). The peralkaline rocks of the Canary Islands generally formed under more restricted conditions, ranging from FMQ +1 to FMQ (Gran Canaria: Troll and Schmincke, 2002, La Gomera: Rodriguez-Losada and Martinez-Frias, 2004, Tenerife: Ablay et al., 1998; Bryan, 2006; Dávila-Harris et al., 2013). Available estimates for São Tomé are similar to those of Terceira, ranging from FMQ -1 to FMQ -2 (Mbowou et al., 2013), whilst those of Ascension extend to slightly more reducing conditions of FMQ -1.8 to FMQ -2.4 (Chamberlain et al., 2016). Data from Ryabchikov and Kogarko (1994) and Marques et al. (1999) constrain the redox conditions of Trindade to FMQ +1.5 to FMQ +2, which may contribute to the lack of a negative Eu-anomaly described above (Figure 5). However, the comparatively reducing estimates for São Tomé, coupled with the similar absence of a negative Euanomaly, imply that redox conditions alone cannot account for this feature. The redox conditions of Madeira, Bouvet, Tristan da Cunha, Gough, St. Helena, and Fernando de Noronha are not well constrained.

\section{Pre-eruptive Water Contents}

The peralkaline magmas of the Atlantic Ocean are invariably hydrous, with a total range in predicted $\mathrm{H}_{2} \mathrm{O}_{\text {melt }}$ values of 1.59.1 wt. \% (e.g., Wolff and Storey, 1983; Wolff et al., 1990; Ablay et al., 1998; Troll and Schmincke, 2002; Pimentel et al., 2015; Eisele et al., 2016; Jeffery et al., 2016b, 2017; D’Oriano et al., 2017; this study; Figures 8B,C). The $\mathrm{H}_{2} \mathrm{O}_{\text {melt }}$ values derived from alkali feldspar-melt hygrometry exhibit a similar range, reaching maximum values of $\sim 8 \mathrm{wt}$. $\%$. The majority of estimates are concentrated within a smaller range of 26 wt. \%, with values of up to 8 wt. \% being limited to a small number of compositions specifically from Gran Canaria (Canary Islands), Trindade, and a single ignimbrite formation from Terceira, Azores (GVI, Jeffery et al., 2017). Overall, $\mathrm{H}_{2} \mathrm{O}_{\text {melt }}$ values exhibit a negative correlation with temperature, with the most hydrous magmas also reporting the lowest temperatures. As observed with temperature estimates, $\mathrm{H}_{2} \mathrm{O}_{\text {melt }}$ also correlates broadly with peralkalinity, with the most strongly peralkaline magmas recording the highest water contents (e.g., Ignimbrite A, Gran Canaria, Canary Islands; Troll and Schmincke, 2002), and the magmas of peralkaline affinity recording the lowest $\mathrm{H}_{2} \mathrm{O}_{\text {melt }}$ values (e.g., the Granadilla eruption, Tenerife; Bryan, 2006). The observed increase in $\mathrm{H}_{2} \mathrm{O}_{\text {melt }}$ values with decreasing temperature suggest that $\mathrm{H}_{2} \mathrm{O}_{\text {melt }}$ concentration is controlled 
by fractional crystallization, becoming enriched in the melt due to the crystallization of a largely anhydrous mineral assemblage.

\section{TOWARD A MODEL FOR THE PERALKALINE MAGMATIC SYSTEMS OF THE ATLANTIC OCEAN}

In the following section, we utilize the petrogenetic processes and pre-eruptive conditions defined above to construct two models which account for the features of Atlantic Ocean Island peralkaline systems. The first provides a general architecture for the magma reservoirs from which the peralkaline felsic magmas of the Atlantic Ocean islands are erupted, and is based upon published data and models, as well as original melt viscosity and crystal-settling calculations undertaken during this study. The second model utilizes a variety of published data and models, and takes a wider view, considering the crustal structure and temporal evolution of the magma plumbing systems which may or may not lead to the formation and eruption of peralkaline felsic magmas.

\section{Zoned Magma Reservoirs}

There is strong evidence to suggest that the upper crustal magma reservoirs in which ocean-island, peralkaline felsic magmas (and their metaluminous equivalents) are stored are compositionally zoned. This pre-eruptive zonation may be recognized by major and/or trace element bulk geochemistry, mineral chemistry, phenocryst content, or thermobarometry ( $c f$. Macdonald, 2012), and may be gradational or sharply defined. For example, Ignimbrite 'A, found on Gran Canaria (Canary Islands) exhibits a chemical transition from comendite at the base of the deposit, to comparatively phenocryst-rich trachyte at the top (Troll and Schmincke, 2002). Similar features are observed in other peralkaline deposits of the Canary Islands, such as Ignimbrite 'TL' (Gran Canaria, Sumner and Branney, 2002), the Ayagaures Ignimbrite (Gran Canaria, Jutzeler et al., 2010), and the deposits of Las Cañadas, Tenerife (Wolff and Storey, 1984; Wolff et al., 1990). A chemically zoned fall deposit on Ascension exhibits similar zonation, ranging from trachyte with peralkaline affinity at the base of the deposit, to basaltic trachyandesite at the top (Chamberlain et al., 2016). In the Azores, the peralkaline ignimbrites of Terceira exhibit more cryptic chemical zonation, with relatively uniform major element compositions, but often considerable variations in incompatible trace elements (e.g., 900-1,350 ppm Zr in the Caldeira-Castelinho Ignimbrite Formation, or 700-2,250 ppm Zr in the Vila NovaFanal Ignimbrite Formation; Gertisser et al., 2010). In this case, the zonation was suggested to result from between 15 and 50\% fractionation within the peralkaline felsic compositions (Jeffery et al., 2017). This zonation is also observed in the results of thermometry and hygrometry, where individual eruptions can exhibit variation in temperature of $>50^{\circ} \mathrm{C}$ and $>2$ wt. $\%$ $\mathrm{H}_{2} \mathrm{O}_{\text {melt }}$ (Jeffery, 2016; D’Oriano et al., 2017). On São Miguel, the shallow magma reservoir of Furnas volcano is interpreted to have repeatedly developed a similarly cryptically zoned reservoir in response to at least 10 tapping events over a period of less than 5,000 years (Jeffery et al., 2016b). The Cão Grande Formation of Santo Antão (Cape Verde) also exhibits examples of preeruptive zonation, with minor variation in major elements, as well as upward (in the deposit) increases in phenocryst content and estimated temperature (up to $100^{\circ} \mathrm{C}$ difference) (Eisele et al., 2016). New hygrometric estimates for the Arico ignimbrite, using the data of Clay et al. (2011), indicate pronounced $\mathrm{H}_{2} \mathrm{O}_{\text {melt }}$ zonation in the underlying magma reservoir, with a range of $\sim$ 4 wt. \%.

Although the upward, gradational transition from more to less evolved deposits (representing the inverse within the original magma reservoir) appears to be the most common form of zonation, this is not always the case. For example, the Montaña Reventada lava flow on Tenerife (Canary Islands) exhibits a sharp interface between basanite and phonolite close to the transition to peralkalinity (Wiesmaier et al., 2011). However, in this instance these authors attribute this to the propagation of a basanitic dyke through an already-present phonolitic magma reservoir, citing the lack of obvious interaction between the two magmas as evidence for the short timescales between initial contact and eruption. Another example of potentially atypical zonation may be found in the Upper Furnas Group (Furnas volcano, São Miguel, Azores), where pronounced changes in trace element concentrations are observed between the early pumice falls and terminal lava domes of two sub-plinian eruptions of mildly peralkaline trachytes, suggesting that a sharp, compositional contact may have been present in the pre-eruptive reservoir (Jeffery et al., 2016b). The Granadilla eruption of Tenerife also exhibits complex, cryptic zonation, with a transition from reverse- to normal-zoning marked by trace element concentrations and phenocryst assemblages (Bryan, 2006). The same eruption also exhibits considerable variation in pre-eruptive temperature $\left(>100^{\circ} \mathrm{C}\right)$ and water content $(>3$ wt. \%).

The development of zonation is a common feature of peralkaline magma systems, having been recognized not only in the studies described above, but also at many other peralkaline centers worldwide (e.g., Pantelleria: Mahood and Hildreth, 1986; Civetta et al., 1998; the East African Rift: Gibson, 1970; Leat, 1984; Macdonald et al., 1994; Peccerillo et al., 2003; Rogers et al., 2004; Marshall et al., 2009; the United States: Novak and Mahood, 1986; Parker and White, 2008). Macdonald (2012) noted that the degree of zonation in a number of individual deposits from Pantelleria, Gran Canaria, the United States, the East Africa Rift, and Mexico showed considerable variation and no clear correlation with eruptive volume, suggesting that magma reservoir geometry, temporal variation, or melt rheology could instead play a role. Ultimately, the mechanisms that are frequently considered to play a role in the formation of pre-eruptive zonation are as diverse as the varieties of zonation themselves, and include fractional crystallization, crystal settling, sidewall crystallization, and crystal mush extraction (see Wolff et al., 2015 and references therein for a detailed review). In particular, the same authors utilize the crystal mush extraction model to advocate the potential role of remelting of cumulates as a means of generating compositional zonation, whereby fusible cumulates are remelted during a replenishment 
event, which contributes heat without matter transfer. This leads to the generation of felsic melt with very similar major element geochemistry to the overlying cupola, but with notably different trace element geochemistry and water content, in an essentially closed system process. In addition to reconciling the seemingly contrary evidence for both fractional crystallization and thermal rejuvenation, this model also accounts for the frequently identified Ba-rich magmas of peralkaline magmatic systems, which are traditionally ascribed to the development of a feldspar-rich layer at the interface between metaluminous and peralkaline magmas within a reservoir, due to the efficiency of crystal settling (e.g., Macdonald et al., 1994; Troll and Schmincke, 2002; Sumner and Wolff, 2003; Macdonald, 2012).

\section{Magma Rheology}

The rheological behavior of peralkaline felsic melts is recognized to be distinct relative to metaluminous and peraluminous melts, due primarily to the decrease in viscosity that results from the presence of excess alkalis (e.g., Bottinga and Weill, 1972; Shaw, 1972; Dingwell et al., 1998; Di Genova et al., 2013). This effect is enhanced by the abundance of volatiles in peralkaline magmas, primarily $\mathrm{H}_{2} \mathrm{O}$, but also $\mathrm{F}$, which substitutes for bridging ions (e.g., Wyllie and Tuttle, 1961; Manning, 1981; Dingwell et al., 1985; Lange, 1994; Whittington et al., 2001; Giordano et al., 2004). This reduction in viscosity undoubtedly plays a role in the syn-eruptive behavior of peralkaline felsic magmas (e.g., Schmincke, 1974; Stevenson et al., 1993; Sumner and Branney, 2002), but also has significant implications for preeruptive processes. For example, fractional crystallization has been demonstrated to be the primary process of differentiation in Atlantic Ocean peralkaline magmatic systems (see above). This indicates that one or more processes of two-phase flow can operate efficiently throughout the system, allowing crystals and melt to be segregated. Classic models for two phase flow (e.g., crystal settling, Bowen, 1928) have been challenged in recent years, often due to the recognition of the difficulties of two-phase flow in voluminous, high viscosity, yet crystal-poor metaluminous felsic magmas, leading to the concept of the crystal mush extraction model (e.g., Bachmann and Bergantz, 2004; Hildreth, 2004). Although such models are highly attractive, due in no small part to their ability to account for many petrological features observed in felsic magmatic systems, their applicability is not universal. For example, Streck (2014) highlighted several case studies, including 'hot and dry' (or A-type) and calc-alkaline rhyolites and granites, in which geochemical compositions of inferred crystal mush and extracted melts were incompatible. Additionally, Macdonald (2012) noted that the application of such models to peralkaline felsic systems may be hindered by the lack of evidence for a crystal mush (i.e., erupted crystal-rich intermediate magmas or 'monotonous intermediates', Hildreth, 1981, cf. Sliwinski et al., 2015). Macdonald et al. (1995, 2008) noted that the rarely erupted intermediate composition magmas of both Silali volcano and the Olkaria volcanic complex, Kenya, were similarly crystal poor to the erupted felsic magmas, suggesting that the presence of an intermediate crystal mush from which felsic magmas are extracted is unlikely (Macdonald, 2012).
To evaluate the efficiency of crystal settling in the low viscosity peralkaline magmas of the Atlantic Ocean, we applied the model of Giordano et al. (2006) to determine representative pre-eruptive melt viscosity values for each of the thirteen case studies described above. This model has been calibrated for a wide range of magma compositions and has been shown by experimental work to be able to reproduce melt viscosity to within $<0.2 \log$ units (Vona et al., 2011). For each center, two viscosity values were calculated on a crystal-free basis: one using a melt composition with the highest peralkalinity index, and one representative of melt compositions that have just crossed the boundary into peralkaline compositions (i.e., with a peralkalinity index in excess of, but as close as possible to, one). In each case, the most peralkaline composition was calculated using the highest available pre-eruptive $\mathrm{H}_{2} \mathrm{O}_{\text {melt }}$ value and lowest suitable temperature value, and the least peralkaline composition was calculated with the lowest available value for water and the highest suitable temperature estimate. Where preeruptive $\mathrm{H}_{2} \mathrm{O}_{\text {melt }}$ estimates were not available, the lowest and highest $\mathrm{H}_{2} \mathrm{O}_{\text {melt }}$ values were set to 4 and 6 wt. \%, respectively (e.g., Gough Island, Fernando de Noronha). Where temperature estimates were not available, a value of $900^{\circ} \mathrm{C}$ was selected for the lowest peralkalinity melt, and a value of $800^{\circ} \mathrm{C}$ was applied for the highest peralkalinity melt. For Tristan da Cunha, a single, mildly peralkaline magma composition was available, allowing the calculation of only a single viscosity value, assuming $6 \mathrm{wt}$ \% $\mathrm{H}_{2} \mathrm{O}_{\text {melt }}$ and a temperature of $900^{\circ} \mathrm{C}$. The effects of additional volatile species such as $\mathrm{F}$ were not considered due to the lack of published data. The normalized major element data applied in each case are given in Table 2.

Overall, melt viscosity values range from $1 \times 10^{1.77}$ to $1 \times 10^{4.77} \mathrm{~Pa} \mathrm{~s}$ (Table 1), confirming that peralkaline felsic magmas of the Atlantic Ocean exhibit viscosities that are equal to or lower than their metaluminous equivalents $\left(\sim 10^{4.5} \mathrm{~Pa} \mathrm{~s}\right.$, Scaillet et al., 1998). Although all of the case studies yield low viscosities, the lowest reported values are generally restricted to the most strongly $\mathrm{SiO}_{2}$-undersaturated compositions, most likely due to the abundance of alkalis compared with $\mathrm{Si}$ (e.g., Cape Verde, Trindade, Fernando de Noronha), suggesting that alkalinity plays the primary role in melt viscosity. Nevertheless, the role of peralkalinity remains, and is probably most significant in the Si-oversaturated magma evolutionary trend, where melt compositions remain mildly alkaline. These values were then used to estimate crystal settling rates via the calculation of Stokes' settling velocities for alkali feldspar crystals, supplemented by the hindered settling equation, which allows the estimation of settling rates in polydispersed suspensions (Bachmann and Bergantz, 2004):

$$
U_{\mathrm{hs}}=U_{\text {Stokes }} \times f(c)
$$

where $U_{\mathrm{hs}}$ is the hindered settling velocity, $U_{\text {Stokes }}$ is Stokes settling velocity, and (c) is a correction factor calculated as:

$$
f(c)=\frac{(1-c)^{2}}{\left(1+c^{1 / 3}\right)^{\left[\frac{5 c}{3(1-c)}\right.}}
$$

where $c$ is equal to the crystal fraction. Crystal diameters were set to $2 \mathrm{~mm}$ and melt densities were set to $2250 \mathrm{~kg} / \mathrm{m}^{3}$ ( $c f$. 
TABLE 2 | Major element compositions (recalculated to 100 wt. \%) used for viscosity calculations.

\begin{tabular}{|c|c|c|c|c|c|c|c|c|c|c|c|c|c|}
\hline Island group & $\mathrm{SiO}_{2}$ & $\mathrm{TiO}_{2}$ & $\mathrm{Al}_{2} \mathrm{O}_{3}$ & $\mathrm{FeO}^{\mathrm{T}}$ & MnO & MgO & $\mathrm{CaO}$ & $\mathrm{Na}_{2} \mathrm{O}$ & $\mathrm{K}_{2} \mathrm{O}$ & $\mathrm{P}_{2} \mathrm{O}_{5}$ & PI & Reference & Sample \\
\hline \multirow[t]{2}{*}{ Iceland } & 73.44 & 0.12 & 13.54 & 2.36 & 0.06 & 0.08 & 0.41 & 5.02 & 4.97 & & 1.01 & Larsen et al., 2001 & SILK-A1 \\
\hline & 73.25 & 0.24 & 10.34 & 5.83 & 0.23 & 0.00 & 0.12 & 5.70 & 4.29 & & 1.36 & Sigurdsson, 1971 & 331 \\
\hline \multirow[t]{2}{*}{ Azores } & 63.89 & 0.80 & 17.40 & 3.17 & 0.20 & 0.66 & 1.20 & 7.15 & 5.37 & 0.15 & 1.01 & Beier et al., 2006 & SM220501-1 \\
\hline & 67.66 & 0.54 & 10.69 & 8.22 & 0.34 & 0.08 & 0.52 & 7.40 & 4.51 & 0.04 & 1.59 & $\begin{array}{l}\text { Mungall and Martin, } \\
1995\end{array}$ & P16 \\
\hline \multirow[t]{2}{*}{$\begin{array}{l}\text { Canary } \\
\text { Islands }\end{array}$} & 69.92 & 0.76 & 14.61 & 3.44 & 0.18 & 0.36 & 0.37 & 6.39 & 3.91 & 0.06 & 1.01 & $\begin{array}{l}\text { Cousens et al., } \\
1990\end{array}$ & V5 \\
\hline & 69.41 & 1.10 & 9.02 & 6.95 & 0.45 & 0.26 & 0.13 & 7.94 & 4.62 & 0.12 & 2.00 & $\begin{array}{l}\text { Kobberger and } \\
\text { Schmincke, } 1999\end{array}$ & KOG16 \\
\hline \multirow[t]{2}{*}{ Cape Verde } & 53.83 & 0.49 & 23.38 & 2.77 & 0.14 & 0.23 & 2.52 & 9.91 & 6.73 & 0.01 & 1.01 & Eisele et al., 2015 & FO024-1 \\
\hline & 54.88 & 0.92 & 15.27 & 5.48 & 0.29 & 0.83 & 1.76 & 13.72 & 6.79 & 0.06 & 1.96 & Eisele et al., 2015 & B012-32 \\
\hline \multirow[t]{2}{*}{$\begin{array}{l}\text { Cameroon } \\
\text { Line }\end{array}$} & 55.26 & 0.49 & 22.65 & 2.84 & 0.11 & 0.43 & 2.00 & 9.94 & 6.19 & 0.09 & 1.02 & $\begin{array}{l}\text { Fitton and Hughes, } \\
1977\end{array}$ & P11 \\
\hline & 57.08 & 0.21 & 21.81 & 1.83 & 0.01 & 0.00 & 0.95 & 12.26 & 5.77 & 0.08 & 1.21 & $\begin{array}{l}\text { Mitchell-Thomé, } \\
1970\end{array}$ & 4 \\
\hline \multirow{2}{*}{$\begin{array}{l}\text { Fernando de } \\
\text { Noronha }\end{array}$} & 57.75 & 0.17 & 22.40 & 1.96 & 0.14 & 0.18 & 1.35 & 9.75 & 6.28 & 0.02 & 1.02 & Lopes, 2002 & 97FN16 \\
\hline & 57.52 & 0.20 & 21.87 & 1.88 & 0.12 & 0.05 & 1.15 & 11.36 & 5.82 & 0.03 & 1.14 & Lopes, 2002 & 89FN88* \\
\hline \multirow[t]{2}{*}{ Ascension } & 67.48 & 0.32 & 15.68 & 4.17 & 0.18 & 0.12 & 0.70 & 6.56 & 4.73 & 0.06 & 1.01 & Jicha et al., 2013 & Al-63 \\
\hline & 72.56 & 0.24 & 10.40 & 3.93 & 0.14 & 0.00 & 0.06 & 8.31 & 4.36 & 0.00 & 1.77 & $\begin{array}{l}\text { Webster and } \\
\text { Rebbert, } 2001\end{array}$ & Al-213G \\
\hline \multirow[t]{2}{*}{ St. Helena } & 60.49 & 0.06 & 19.97 & 3.99 & 0.19 & 0.00 & 1.23 & 8.88 & 5.13 & 0.06 & 1.01 & $\begin{array}{l}\text { Kawabata et al., } \\
2011\end{array}$ & SH-85 \\
\hline & 60.87 & 0.08 & 18.00 & 3.73 & 0.14 & 1.04 & 0.60 & 8.83 & 5.27 & 1.45 & 1.12 & Asavin et al., 1997 & CE6 \\
\hline \multirow[t]{2}{*}{ Trindade } & 54.62 & 0.64 & 21.70 & 3.66 & 0.13 & 0.98 & 2.68 & 9.22 & 6.20 & 0.17 & 1.01 & $\begin{array}{l}\text { Marques et al., } \\
1999\end{array}$ & TR-21 \\
\hline & 52.31 & 0.31 & 20.77 & 4.73 & 0.15 & 0.82 & 2.27 & 13.33 & 5.13 & 0.18 & 1.32 & $\begin{array}{l}\text { Mitchell-Thomé, } \\
1970\end{array}$ & 2 \\
\hline $\begin{array}{l}\text { Tristan da } \\
\text { Cunha group }\end{array}$ & 63.31 & 0.47 & 18.47 & 2.02 & 0.12 & 0.35 & 1.36 & 7.13 & 6.72 & 0.05 & 1.03 & Reagan et al., 2008 & 2004TDC2 \\
\hline Gough Island & 61.67 & 0.14 & 18.04 & 5.41 & 0.25 & 0.18 & 1.27 & 7.43 & 5.57 & 0.03 & 1.01 & Le Roex, 1985 & G19C \\
\hline \multirow[t]{2}{*}{ Bouvet Island } & 68.43 & 0.31 & 14.64 & 4.35 & 0.13 & 0.00 & 1.58 & 6.03 & 4.50 & 0.03 & 1.01 & Prestvik et al., 1999 & B16 \\
\hline & 71.15 & 0.31 & 12.72 & 4.19 & 0.11 & 0.02 & 0.78 & 5.80 & 4.89 & 0.03 & 1.17 & $\begin{array}{l}\text { Bailey and } \\
\text { Macdonald, } 1970\end{array}$ & $\mathrm{~B} 2$ \\
\hline
\end{tabular}

PI, Peralkalinity index. All values (excluding Pl) are reported as wt. \%.

Jeffery et al., 2017). Settling rates were calculated for the highest and lowest viscosities calculated above, although it must be acknowledged that the lowest viscosity value of $1 \times 10^{1.77}$ (Cape Verde) represents the most extreme end of the compositional spectrum present in the Atlantic Ocean magmatic systems (e.g., highly alkaline, high water content, strongly peralkaline). As such, the values calculated for these conditions may not be broadly applicable, but rather an end-member achievable under specific circumstances. On this basis, settling rates for the most peralkaline compositions range from $143 \mathrm{~m} \mathrm{yr}^{-1}$ (hindered settling assuming $40 \%$ crystallinity) to $734 \mathrm{~m} \mathrm{yr}^{-1}$ (unhindered settling). The least peralkaline compositions return settling rates of $0.43 \mathrm{~m} \mathrm{yr}^{-1}$ (unhindered settling) to 0.08 $\mathrm{m} \mathrm{yr}^{-1}$ (hindered settling assuming 40\% crystallinity). These values indicate that, although crystal settling may be rendered largely ineffective over short timescales by high melt viscosity in metaluminous felsic magmas, it may continue to play a role during the differentiation of peralkaline felsic magmas, even during the latest stages of melt evolution, and particularly in the most Si-undersaturated melts (e.g., Pfaff et al., 2008;
Neave et al., 2012; Lindhuber et al., 2015; Jeffery et al., 2016b, 2017).

\section{A Note on the Applicability of Crystal Mush Extraction Models to Peralkaline Systems}

The commonly crystal-poor felsic magmas of the Atlantic Ocean may be accounted for by low melt viscosity, which facilitates the gravitational settling of alkali feldspar crystals over short timescales. This may also appear to preclude the application of crystal mush extraction models in such systems; however, it is argued here that the two are not mutually exclusive, and such a model may still be useful in accounting for the petrological features of peralkaline systems. The primary arguments against a crystal mush model in peralkaline systems are efficient crystal settling (which, to some extent, removes the need for mush extraction as a two-phase flow mechanism) and the apparent absence of erupted crystal-rich magmas termed monotonous intermediates (which are typically interpreted to represent 
erupted portions of a crystal mush; e.g., Hildreth, 1981, 2004; Bachmann and Bergantz, 2004). Macdonald (2012) noted the lack of clear monotonous intermediates in peralkaline systems, but also highlighted the frequent identification of a feldspar (and Ba) -rich layer (e.g., Leat, 1984; Macdonald et al., 1994; Troll and Schmincke, 2002; Sumner and Wolff, 2003), which may be somewhat comparable to true monotonous intermediates.

We suggest that the predominance of fractional crystallization within the magmatic systems of this study implies that, to generate even the relatively small volumes of erupted peralkaline magmas observed in the Atlantic Ocean magmatic systems, considerably larger volumes of crystalline material must be deposited within the upper crust (although the actual ratio of residual to erupted volumes may be highly variable; see above). Crystals forming within the felsic peralkaline magmas must settle rapidly, and either accumulate to form a mush zone, or be entirely assimilated and reincorporated chemically back into the melt. Although petrographical observations and concentrations of $\mathrm{Ba}$ have been used to identify the latter process (e.g., Macdonald et al., 1994, 2008; Sumner and Wolff, 2003; D'Oriano et al., 2017; Jeffery et al., 2017), its efficiency is not constrained, and must relate to the total temperature gradient present within an individual magma reservoir. We therefore suggest that a 'mushy' zone inevitably forms at the base of the lower crustal magma reservoirs, which may then contribute melts to an overlying cupola via filter pressing, as well as potentially via partial melting in response to replenishment events (Wolff et al., 2015).

The absence of monotonous intermediates may simply result from the difficulty of erupting such highly crystalline material. Furthermore, the eruption of such material may be achievable only by receiving an input of comparatively hot, rejuvenating magma, sufficient in scale to unlock the crystal mush, potentially homogenizing the pre-eruptive reservoir in the process (e.g., Southern Rocky Mountain volcanic field; Huber et al., 2012). The applicability of such a process in the low volume systems of the ocean islands is unconstrained; however, the flux rate of ocean island magmatic systems, such as those of the Atlantic, is undoubtedly lower than that of the Southern Rocky Mountain volcanic field, suggesting that a large-scale replenishment event which unlocks the mush and homogenizes the reservoir is improbable. Furthermore, the frequency of zoned eruptive deposits in peralkaline systems (and beyond) suggests that if mush rejuvenation occurs in these systems, it must occur over sufficiently short timescales to prevent reservoir homogenization. Crystalline, autolithic nodules, typically of syenitic composition, may seem like a potential candidate for the peralkaline form of monotonous intermediates; however, where these rocks are found as inclusions within erupted lithologies (within the Atlantic Ocean and elsewhere), they often exhibit mineral assemblages representative of more extreme compositions than those of the erupted magmas. They are therefore frequently interpreted as the result of near-complete, in situ, bulk solidification at the margins of a magma reservoir, making them effectively the plutonic equivalents of the erupted peralkaline magmas (e.g., Harris, 1983; Wolff, 1987; Turbeville, 1993; Widom et al., 1993; Ridolfi et al., 2003, 2006; Jeffery et al., 2016b, 2017). These rocks, alongside some examples of exposed shallow intrusions, appear to be the only truly agpaitic rocks available in oceanic island systems (Marks and Markl, 2017). We therefore suggest that the absence of erupted monotonous intermediates reflects two processes: (1) the overall difficulty in erupting intermediate crystal mush due to the significant density contrast between them and overlying, hydrous peralkaline magmas, and (2) the potential for intermediate magmas to be essentially absent due to the mixing of mafic magmas into an established felsic system, being instead incorporated directly into felsic magmas, or becoming trapped within a crystal mush, where they may provoke partial melting (see below).

In summary, crystal mush extraction models are compatible with the primary petrological features of the peralkaline magmatic systems of the Atlantic Ocean. In fact, the rheological properties of the melt may enhance the potential for the development of cumulate mush at the base of the magma reservoir, with a crystal poor, compositionally zoned cupola of magma overlying it (Figure 9).

\section{Constructing a Unifying Conceptual Model for the Peralkaline Magmatic Systems of the Atlantic}

Existing data and models for the peralkaline magmatic systems of the Atlantic Ocean provide evidence for open system processes, with fractional crystallization representing the primary petrogenetic process, alongside variable contributions from magma mixing processes during replenishment events, and contamination with various crustal lithologies. In published models, the formation of peralkaline felsic magmas is generally limited to the uppermost crust $(<5 \mathrm{~km})$, where the extended fractionation of primarily alkali feldspar drives metaluminous progenitor magmas (phonolites, trachytes, and rhyolites) toward peralkalinity, typically within an evolved cap in the uppermost portion of the reservoir (e.g., Wolff, 1985, 1987; Neumann et al., 1999). Other magma reservoir models invoke a stratified magma reservoir, potentially containing three or more distinct melt compositions, which may be mixing with one another to varying degrees (e.g., Widom et al., 1992; Freundt and Schmincke, 1995; Sumner and Branney, 2002; Troll and Schmincke, 2002; Sumner and Wolff, 2003; Snyder et al., 2007; Jeffery et al., 2016b). Such models may also be applicable to a cupola overlying a crystal mush, as well as models based around liquid magma reservoirs (e.g., Sliwinski et al., 2015). Progenitor magmas are themselves the end product of fractionation from a mafic parent, which may range from transitional basalt to basanite or foidite. Many eruptive centers exhibit evidence for a polybaric fractionation process in their underlying magmatic systems, with a significant mafic magma reservoir situated close to the crustmantle boundary (e.g., Ablay et al., 1998; Hansteen et al., 1998; Schwarz et al., 2004; Klügel et al., 2005; Beier et al., 2006; Hildner et al., 2011, 2012; Zanon and Frezzotti, 2013; Jeffery et al., 2017; Weit et al., 2017). In some instances, only a small portion of the fractionation history of the erupted peralkaline magmas occurs at these lower crustal depths, with mafic compositions generally evolving toward broadly hawaiitic or tephritic compositions before ascending into the upper crust, where they may then 


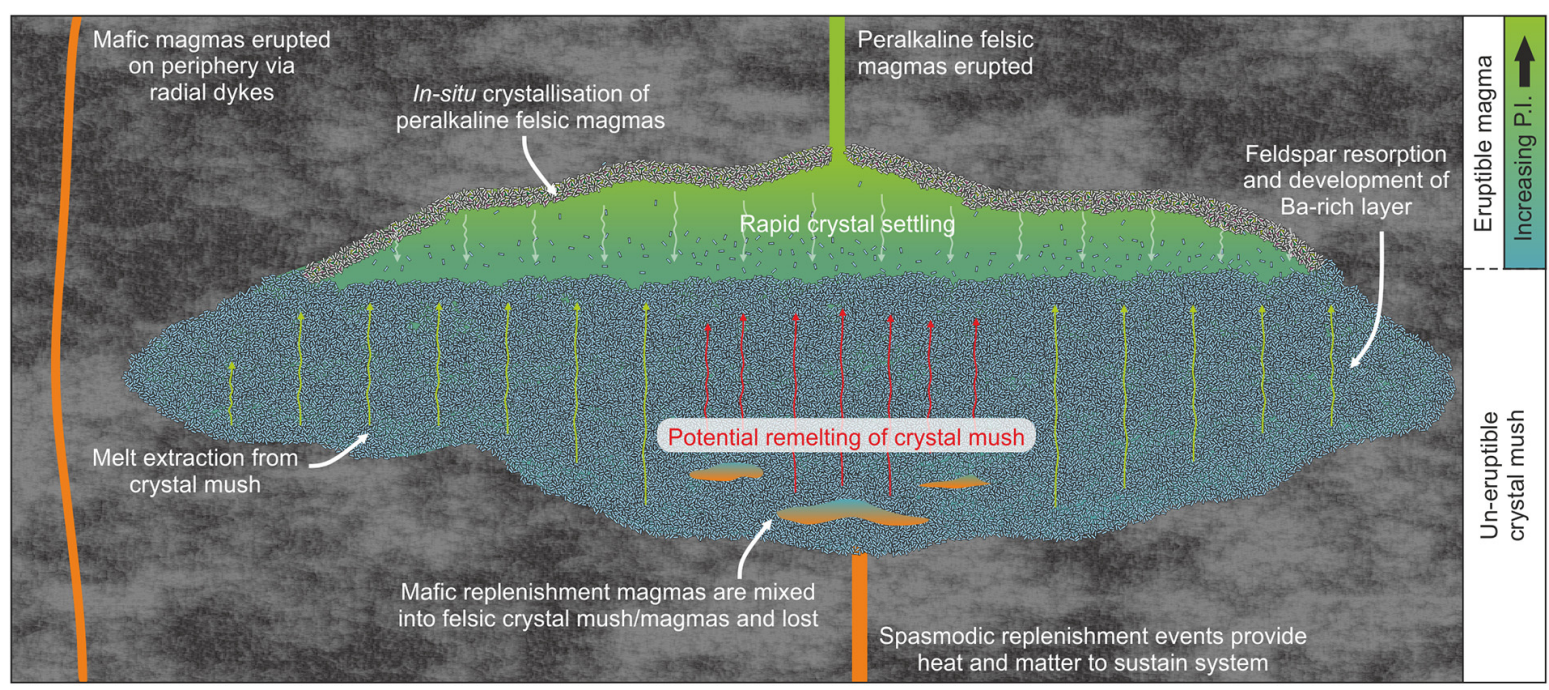

FIGURE 9 | Schematic model for an upper crustal magma reservoir containing peralkaline felsic magmas. The model aims to reconcile the crystal mush-extraction model with low viscosity peralkaline systems, and includes a number of features which are commonly recognized in such systems, including: (1) the development of compositional zoning within a crystal poor cupola, (2) the formation of a crystal- and Ba-rich lower layer in the cupola where settling alkali feldspars can be recycled chemically, (3) the potential for ascending mafic magmas to be lost via incorporation into the felsic reservoir, and the subsequent development of a shadow zone at the surface, (4) the accumulation of a substantial crystal mush pile, from which melt can be extracted via filter pressing, or which can itself be remelted by replenishment magmas, and (5) the near-complete solidification of peralkaline silicic magmas in the thermal boundary zone of the cupola, forming intrusive peralkaline lithologies which may be sampled during eruption.

continue to evolve toward felsic compositions in a shallow crustal magma reservoir, or travel directly to the surface. Direct transport of mafic magmas to the surface may only be possible by circumventing the shallow magma reservoirs, leading to the development of a 'shadow zone' at the surface, marked by central, polygenetic volcanoes which produce exclusively felsic magmas (e.g., Martí and Gudmundsson, 2000; Ebinger and Casey, 2001; Jónasson, 2007; Peccerillo et al., 2007; Acocella, 2014). For example, on São Miguel (Azores), moderately evolved mafic compositions are erupted only in fissure zones between the three central volcanoes (Booth et al., 1978). The development of such arrangements is likely to be dependent upon the stability of the upper crustal reservoir; in theory, the more established the felsic cap becomes (depending upon input via replenishment and output via eruption, or potentially solidification), the lower the chances of seeing evidence for a mafic component in the erupted magmas (Macdonald, 2012). Direct interaction between central and peripheral magmas has been observed on Tenerife (Canary Islands, Wiesmaier et al., 2011), where a sharp compositional interface within a single eruption marks the emplacement of a mafic sill into a colder, felsic magma reservoir, which initiated eruption. Overall, these concepts are broadly applicable to the magmatic centers of the Atlantic Ocean. However, two exceptions that should be noted are Ascension and Santo Antao, where peralkaline magmas may have been formed at unusually high pressures ( 250 to $400 \mathrm{MPa}$ ), which broadly equates to the lower crust. Furthermore, the peralkaline magmas of Ascension are suggested to have formed via closed system fractional crystallization (Chamberlain et al., 2016), a feature which makes them extremely unusual amongst the peralkaline magmas of the
Atlantic. One possible contributing factor may be the greater depth of the magma reservoir, which places low temperature peralkaline magmas against comparatively high-solidus mafic country rock, inhibiting any form of crustal assimilation during the later stages of evolution.

We propose the following three stage model which incorporates the published data described above and accounts broadly for each of the peralkaline magmatic systems of the Atlantic Ocean (Figure 10). In stage 1, magmatism is initiated with mantle-derived mafic magmas ascending to generate a shield volcano at the surface, potentially stalling in the upper mantle and the crust-mantle boundary and differentiating via fractional crystallization to compositions such as hawaiite or tephrite/basanite. The transition to stage $2 \mathrm{a}$ is envisaged to occur when ascending mafic magmas are able to stall in the shallow crust and fractionate toward peralkaline felsic compositions. The factors controlling this are diverse but are likely to include both large scale and regional structural trends and processes. For example, peralkaline magmas in the Azores archipelago are concentrated on the islands of Graciosa, Terceira, and São Miguel, all three of which lie on a major extensional feature named the Terceira rift. The active extension in the crust may have facilitated formation of upper crustal magma reservoirs, effectively accelerating peralkaline magmatism. In order for this upper crustal reservoir, which may take the form of one or more discrete magma reservoirs, or potentially an intrusive complex of dykes and sills, to be maintained in the relatively cool upper crust, it must receive regular input from the deeper portion of the system, which provides thermal energy and matter. At this point, the liquid line of descent is greatly extended to 


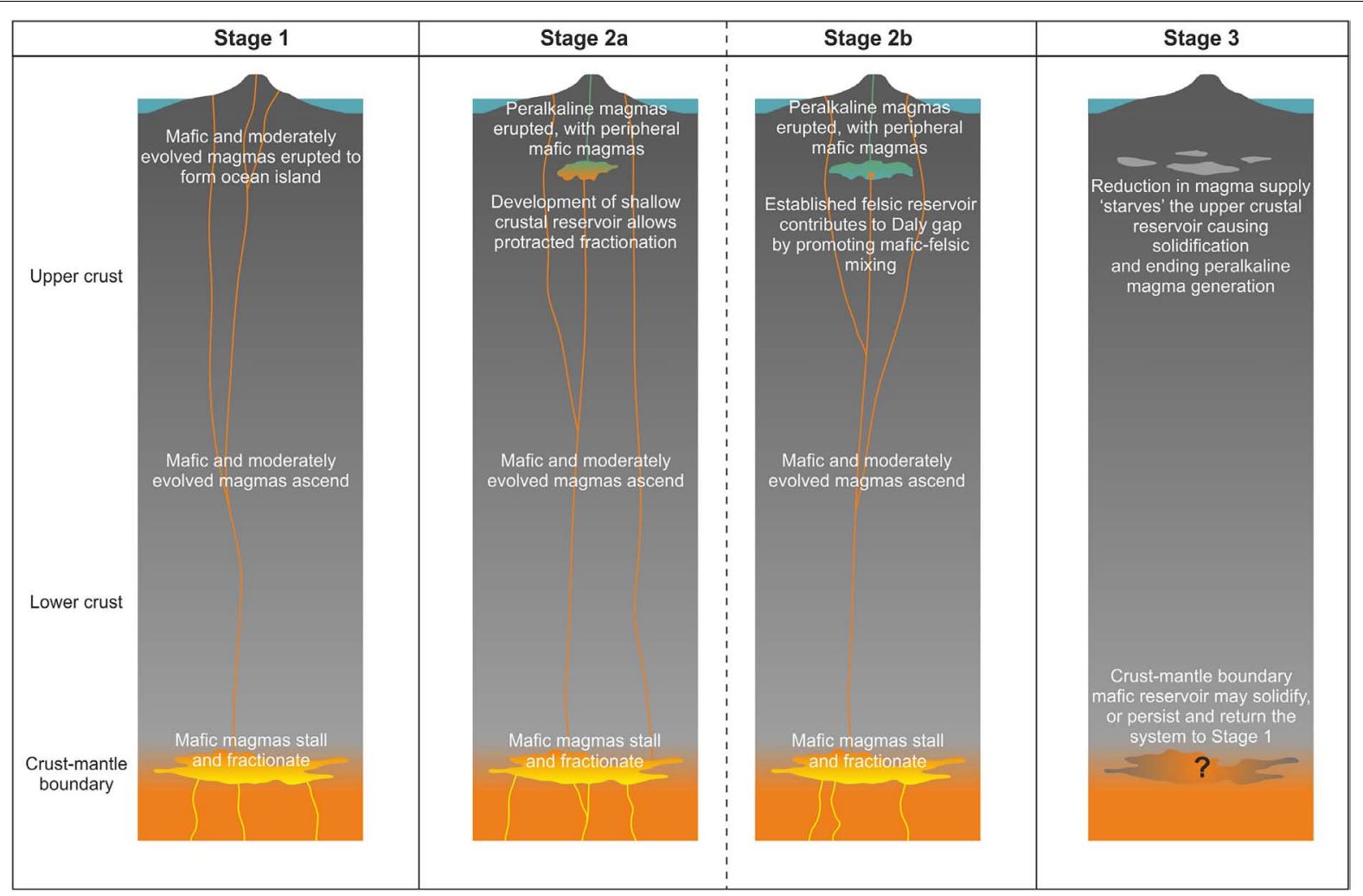

FIGURE 10 | Three-stage conceptual model for the origin, development, and subsequent cessation of peralkaline felsic magmatism beneath the Atlantic Ocean Islands. See text for discussion.

include more evolved products, and felsic crystal mush begins to accumulate in the shallow crust. True intermediate magmas must also exist in the shallow crustal reservoir, trapped beneath less dense, more volatile-rich felsic magmas. The shallow system may be tapped in response to fractional crystallization-induced magmatic overpressure, or potentially by the replenishment events themselves, whilst the deeper portions of the system may still be represented by magmas which ascend from the lower crust and do not interact with the shallow system, leading to eruptions of mafic magmas on the periphery of the central volcano. The establishment of a shallow crustal felsic magma reservoir is therefore envisaged to generate a shadow zone, where only felsic magmas are erupted at the surface, and ascending mafic magmas are only able to reach the surface via peripheral vents.

Stage $2 \mathrm{~b}$ occurs if the upper crustal reservoir is maintained for long enough, in which case it is envisaged that magma mixing becomes more significant, with batches of ascending mafic magmas being mixed into comparatively large volumes of felsic magma and crystal mush. In effect, the liquid line of descent is cut into two segments (e.g., basalt to hawaiite, metaluminous trachyte to peralkaline trachyte). This may be manifested as a Daly gap, which is evident at many of the Atlantic Island magmatic systems (Figure 3). The felsic magmas in the upper crustal reservoir are maintained by replenishment events, effectively reversing the effects of fractional crystallization and generating hybrid intermediate magmas rather than 'true' intermediates derived via fractional crystallization of mafic progenitors (e.g., Storey et al., 1989; Ferla and Meli, 2006; Jeffery et al., 2017). The same replenishment events may also contribute to the felsic magma reservoir by partially melting previously deposited felsic cumulates, or even completely solidified felsic magma batches. Wiesmaier et al. (2013) demonstrated that the latter plays a distinct role in the formation of felsic magmas on Tenerife, and most likely becomes more important as such magmatic systems get older and the composition of the upper crust is made steadily more felsic. It might therefore be expected that this process is most significant in the Canary Islands, Cape Verde, and the Cameroon Line, where the magmatic systems are old enough to have added significant volumes of felsic material to the crust. By contrast, younger magmatic systems such as those of the Azores, Bouvet, Gough, Trindade, and Ascension, may be too young to have considerable reserves of low-solidus, felsic crust. The development of an established cap to the magma system, comprising low density, hydrous peralkaline magmas, is likely to strengthen the shadow zone by completely inhibiting the eruption of higher density magmas, whether they are highly phyric magmas derived from the felsic crystal mush, or dense, mafic magmas.

If the volume of replenishment decreases to levels below those required to maintain the upper crustal system, then the 
system will enter stage 3 . Without adequate heat and matter to sustain it, the upper crustal magma reservoir cools and solidifies, effectively shutting down the generation of peralkaline felsic magmas. Eruption of mafic magmas derived from the lower crustal magma reservoir may continue, but peralkaline felsic magmas cannot be generated until the upper crustal magma reservoir is re-established. If the overall magma flux of the system increases such that a shallow crustal reservoir can be reestablished, then a resurgence in peralkaline magmatism may occur, following a period of mafic magmatism (e.g., La Gomera, Canary Islands).

\section{The Onset of Peralkaline Magmatism Within the Life Cycle of Atlantic Ocean Islands}

To further evaluate the development of peralkaline magmatism in the Atlantic Ocean, we now consider the onset of peralkaline magmatism relative to the respective ages of each Atlantic island. In Figure 2, the subaerial age of each of the Atlantic islands is plotted, and, where data permit, the earliest known occurrence of felsic magmatism, which we consider to represent the transition from stage 1 to stage 2 . In many cases, there is a clear termination of felsic magmatism; for example, on Fernando de Noronha, where peralkaline felsic magmatism occurred between 12.5 and $9.4 \mathrm{Ma}$, followed by a period of $\sim 3 \mathrm{~m}$.y. of quiescence, and then a resurgence in exclusively mafic magmatism. In this case, this represents the transition from stage 2 to stage 3 , followed by a return to stage 1 .

Beginning with the Azores, the islands of Graciosa, Terceira, and São Miguel appear to be in stages $2 \mathrm{a}$ to $2 \mathrm{~b}$ (Table 1), with established peralkaline magma reservoirs. Additionally, the islands of Corvo, Flores, and Faial may also be in the early stages of Stage $2 \mathrm{a}$, as they have begun to produce more evolved compositions (e.g., benmoreite, metaluminous trachyte). By contrast, the islands of Pico and São Jorge are still in stage 1, with almost exclusively mafic products. Santa Maria is considerably older than any other Azorean island, and although it has an exclusively mafic character, its heavily eroded form suggests that any prior felsic magmatism may have been lost. As such, it most likely lies between stages 3 and 1 .

The Canary Islands are generally older than the Azorean islands, and it is perhaps not surprising that some appear to be in the more advanced stages of activity. For example, La Gomera, and Gran Canaria are all characterized by initial periods of mafic magmatism (stage 1), followed by one or more periods of felsic magmatism (stages 2), and, subsequent quiescence (stage 3). In the case of Gran Canaria, and also Fuerteventura, mafic activity began again following the termination of felsic magmatism, suggesting a return to stage 1 . It is also noteworthy that $\mathrm{La}$ Gomera may have passed through the full cycle twice, with two distinct phases of peralkaline felsic magmatism separated by $\sim 2.5 \mathrm{Ma}$, and an eventual complete cessation of magmatism indicating stage 3 . Despite its age, Lanzarote appears to be in stage 1, with no reported felsic magmas during its $\sim 15$ m.y. lifespan. By contrast, Tenerife entered stage 2 after at least $~$ 5 m.y. in stage 1 . Like Tenerife, the two youngest islands (La
Palma and El Hierro) are in stage 2, despite their comparative youth.

The islands of the Cape Verde archipelago show similar diversity; Santo Antao, Fogo, and Brava are all in stage 2, with peralkaline felsic magmas being produced until the present day. Sal may have approached stage 2 , with some peralkaline felsic magmas reported. Santiago and Maio, despite their considerable age, remain in stage 1 , although magmatism on Maio appears to have already ceased without progressing beyond stage 1 . The remaining islands of São Nicolau, São Vicente, and Boa Vista are all in stage 3 , having previously produced peralkaline felsic magmas over periods of around 1-3 Ma. More recent mafic activity on São Nicolau and São Vicente may indicate the transition from stage 3 to stage 1 .

The oceanic sector of the Cameroon Line includes some of the oldest islands in the Atlantic Ocean. The three older islands have clearly entered, or are approaching, stage 2, with peralkaline felsic rocks found on São Tomé, Principe, and metaluminous felsic rocks on Pagalu. Only the considerably younger island of Bioko remains in stage 1 , with exclusively mafic compositions reported. Ascension Island remains in stage 2, having produced peralkaline felsic magmas during its entire subaerial lifespan of $\sim 1 \mathrm{Ma}$. In the Madeira archipelago, the predominance of mafic magmas and the absence of any reported peralkaline compositions suggests that all three islands are in stage 1, despite their age. In fact, the occurrence of comparatively rare metaluminous trachytes and rhyolites may indicate the onset of stage 2 on Madeira and Porto Santo. By contrast, the Desertas Islands most likely never progressed further than stage 1 before magmatic activity ceased. Bouvet Island is hard to evaluate due to the lack of data; however, the occurrence of peralkaline felsic magmas and its young age suggest that it is currently in stage 2 .

In the Tristan da Cunha archipelago, the island of Tristan appears to be approaching stage 2. Despite the youth of the island $(\sim 0.2 \mathrm{Ma})$, evolved compositions such as metaluminous phonolites and trachytes have been erupted, alongside volumetrically more abundant mafic compositions. Due to its highly eroded form, and the occurrence of peralkaline felsic eruptive products, Inaccessible Island should be considered to be in stage 3 , having produced peralkaline magmas, and subsequently ceasing volcanism altogether. The situation is similar for the considerably older Nightingale Islands, and although there are no reported peralkaline compositions, metaluminous felsic rocks are present. Considering the islands' highly eroded form, many of the products of stage 2 may have been destroyed.

Gough Island is clearly at the onset of stage two, with an initially mafic history, and the very recent $(\sim 0.2 \mathrm{Ma})$ development of peralkaline felsic magmatism. This period of approximately $0.1 \mathrm{~m} . \mathrm{y}$. ended with a phase of mafic magmatism, suggesting that Gough may in fact have progressed to stage 3, making its peralkaline phase particularly short compared to other examples in the Atlantic Ocean. The magmatism of St. Helena is characterized by a lengthy period of mafic magmatism $(\sim 5 \mathrm{~m}$. y.), followed by a longer period which included volumetrically inferior peralkaline felsic magmas, and lasted until the present day, suggesting that St. Helena is currently in stage 2. In this 
instance, the lack of a well-developed Daly gap may indicate that the system remains in stage $2 \mathrm{a}$.

As described above, Fernando de Noronha appears to be in Stage 1, having erupted peralkaline felsic magmas during its early subaerial lifespan, followed by a 3 m.y. period of quiescence, and subsequent renewed mafic magmatism. The island of Trindade (and nearby Martin Vaz) may be similar to Fernando de Noronha. Although the lack of available data makes any evaluation of Martin Vaz difficult, the peralkaline felsic magmatism of Trindade is limited exclusively to the first half of its subaerial life, followed by a period of $\sim 2$ m.y. during which only mafic and ultramafic compositions were produced. Overall, it seems likely that a shallow crustal magma reservoir existed early in Trindade's lifespan, but was subsequently shut down, suggesting that it has re-entered stage 1 .

We choose to consider Iceland separately when applying the model described above. In terms of its scale, geodynamic setting, reported magma compositions, and petrogenetic processes, Iceland stands apart from the remaining Atlantic islands. Nevertheless, Icelandic peralkaline magmatism is restricted to polygenetic volcanic centers, as seen elsewhere, and the general structure of those magma chambers which lie furthest from the rift, and which have therefore been linked to fractional crystallization (Carmichael, 1964; Macdonald et al., 1990; Furman et al., 1992a; Sigmarsson et al., 1992; Hards et al., 2000; Prestvik et al., 2001; Martin and Sigmarsson, 2007), may be very similar to those observed elsewhere. On this basis, it might be suggested that Iceland is currently in stage 2 of the presented model. We suggest that the abundance of peralkaline felsic magmatism that is derived from crustal melting is linked to the overall magma flux, which might be expected to be greater in the rift zones of Iceland than at any of the off-rift Atlantic hotspots (e.g., White, 2010, and references therein). It follows that the introduction of comparatively large volumes of mafic magma into the shallow crust could provide sufficient heat and time to melt the predominantly refractory oceanic crust, whereas the comparatively low volumes generated in locations such as St. Helena and Tristan da Cunha are unable to melt anything other than fusable crystal mush.

Overall, there is no clear correlation between the age of an Atlantic magmatic system and the development of peralkaline magmas. For example, Madeira Island may now be approaching a point at which peralkaline felsic magmas can be formed after $\sim 6$ m.y. of subaerial activity. By contrast, Ascension, Bouvet, and Tristan have all developed peralkaline felsic magmas in 1 m.y. or less. Some of the Atlantic islands have been subaerial for more than 15 m.y. (e.g., Maio, Lanzarote) but have not produced peralkaline felsic magmas, and yet the young $(<1$ Ma) Azorean islands of Graciosa, Terceira, and São Miguel have all developed prominent peralkaline volcanic centers. Clearly, the conditions required to generate peralkaline felsic magmas occur sooner in some systems than in others. In many respects, this is unsurprising, as it seems likely that the primary control on the development of peralkaline felsic magmas is the overall flux of the magmatic system, which bears little relation to the subaerial exposure of the lava pile. We suggest that there must be a 'peralkalinity window' in the flux of the magmatic system in which the magma input rate into the shallow crust is sufficient to maintain active magma bodies over the timescales required to allow differentiation, and not so much that it accelerates the eruptive rate to the point at which magmas are not able to differentiate toward peralkaline compositions. As such, the generation of peralkaline felsic magmas is dependent upon the ability of the upper crustal magma reservoirs to remain active. The abundance of peralkaline magmas throughout the Atlantic Ocean islands implies that, in any individual magmatic system, these conditions are frequently, but not inevitably, met as part of the larger scale processes which drive magmatism in these regions. This is undoubtedly supplemented by secondary controls, such as tectonics. The Azores provide one example where the development of peralkaline felsic magmas appears to be concentrated on a large-scale extensional feature, which may accelerate the development of peralkaline felsic magmas by facilitating the formation of upper crustal magma reservoirs.

\section{FUTURE RESEARCH DIRECTIONS}

Recent advances in our understanding of magma reservoirs have fundamentally shifted the perception of how magmas are stored and evolve in the crust (e.g., Bachmann and Bergantz, 2004; Cashman and Sparks, 2013; Cashman and Giordano, 2014; Streck, 2014; Bachmann and Huber, 2016; Cashman et al., 2017). Similarly, considerable effort applied to the understanding of peralkaline magmatic systems in continental rifts has resulted in widely applicable models for the open system development of such systems in locations such as the East Africa Rift (e.g., Bailey and Macdonald, 1975; Black et al., 1997; Peccerillo et al., 2003, 2007; Macdonald and Scaillet, 2006; Ren et al., 2006; Macdonald et al., 2012). However, the applicability of these models and concepts of magma storage and evolution to the low volume, peralkaline magmatism of the Atlantic Ocean islands is often not well constrained. This is primarily due to the challenges associated with available data for the petrological reconstruction of subvolcanic magmatic systems. Although examples such as the Canary Islands are well studied (e.g., Freundt and Schmincke, 1995; Ablay et al., 1998; Neumann et al., 1999; Sliwinski et al., 2015), there remain examples where geochemical datasets for peralkaline felsic magmas in the Atlantic Ocean are small, incomplete, or essentially absent. Similarly, some settings such as Gough Island and Bouvet Island also lack sufficient geochronological data to develop a rigorous temporal framework of island evolution as a whole.

Overall, the felsic magmas of the Atlantic Ocean islands have received less attention than their mafic counterparts. As such, it is suggested here that the thorough testing of the models and concepts discussed in this contribution is dependent upon expanding the available dataset for Atlantic felsic peralkaline rocks, particularly in the less well-constrained locations such as Gough Island and Bouvet Island. We therefore suggest that further research should be aimed at constraining: (1) the precise $\mathrm{P}-\mathrm{T}-\mathrm{fO}_{2}-\mathrm{X}$ conditions of the magma reservoirs which 
produce and store peralkaline magmas in the oceanic crust, and (2) the overall timescales of magmatism. In the case of the former, the actual geometry of the underlying magma reservoirs is often poorly constrained, suggesting that further study into the pre-eruptive storage conditions of the erupted peralkaline magmas, particularly the relative depths of magma storage. Furthermore, the detailed study of individual, wellconstrained eruptive units can yield valuable insights into the potentially zoned pre-eruptive reservoir. Similarly, where present, plutonic ejecta represent an opportunity to investigate processes such as in situ crystallization, melt extraction, mush remobilisation, and cannibalization. For the latter topic, we argue here that the generation of peralkaline felsic magmas in the oceanic magmatic systems of the Atlantic tends toward cyclicity, with individual magmatic systems having the potential to partially or completely pass through one or more cycles of magmatism, controlled largely by the overall magmatic flux of the system. The temporal model presented here for each of the Atlantic Islands could be improved via higher resolution dating, which may highlight higher-order variations in the production of peralkaline felsic magmas. Similarly, the determination of timescales for magmatic processes shows great promise in enhancing our understanding of how these relatively low volume magma chambers form, evolve, and eventually terminate (Bachmann and Huber, 2016). Although zircon is often not a fractionating phase in peralkaline rocks, U-series disequilibria of glass separates have been used to constrain the rates of evolution of peralkaline felsic magmas, providing timescales for pre-eruptive processes such as fractionation and the development of zonation (e.g., Widom et al., 1992; Snyder et al., 2007). Furthermore, diffusion modeling may provide a robust indication of timescales of processes such as mush reactivation and magma mixing (e.g., Martin et al., 2008; Matthews et al., 2012; Till et al., 2015). Finally, a key component in the continued investigation of the precise state of the described, upper crustal felsic magma reservoirs is the consideration of their thermal state. Numerical modeling of the thermal evolution of such systems will provide invaluable insights into the timescales over which a given magma reservoir can exist without entirely solidifying without the input of additional heat via replenishment events (Annen et al., 2008; Gelman et al., 2013), which may be of particular interest in the potentially low-volume magma reservoirs of ocean islands ( $c f$. Bachmann and Huber, 2016 and references therein).

\section{CONCLUSION}

Peralkaline magmatism occurs frequently throughout the various magmatic systems of the Atlantic Ocean islands. The generation of such magmas is ultimately controlled by fractional crystallization of mantle-derived mafic magmas. Nevertheless, there is abundant evidence for open system evolution. Crustal assimilation may occur at any point in the system, with assimilants ranging from mafic lower crust to upper crustal felsic lithologies such as crystalline mush or previously intruded and solidified magmas. Older magmatic systems may be more susceptible to assimilation of the latter due to the continued accumulation of low-solidus felsic material in the upper crust. Magma mixing is also recognized in the majority of systems and includes mixing between mafic and felsic end-members, two variably felsic end-members, and the remobilisation of crystal mush. This process frequently leads to the formation of hybrid magmas which lie compositionally within the Daly gap, a feature which is recognized at many of the Atlantic islands volcanic centers. The peralkaline felsic magmas of the Atlantic are formed primarily in established shallow crustal reservoirs (generally between 2 and $5 \mathrm{~km}$ depth), which are fed by replenishment from mafic magma reservoirs at greater depth, typically around the crust-mantle boundary. The peralkaline felsic magmas of the upper crustal system are invariably hydrous, with $\mathrm{H}_{2} \mathrm{O}_{\text {melt }}$ values that typically range from 2 to $6 \mathrm{wt}$. \%, and are frequently compositionally zoned. Zonation may be observed in major element chemistry or crystal content, or may be more subtle, recognizable only in trace element geochemistry and/or pre-eruptive temperatures and $\mathrm{H}_{2} \mathrm{O}_{\text {melt }}$ contents. The upper crustal magma reservoirs are likely to include a lower crystal mush which forms due to the considerable degree of fractionation which occurs. Crystal mush formation may be accelerated by the low viscosity of the peralkaline magmas, which allows crystal settling to remain a viable mechanism of two-phase flow even at temperatures below $800^{\circ} \mathrm{C}$. This potential for the rapid accumulation of alkali feldspar-based crystal mush suggests that the extraction of melt from crystal mush, as well as remelting of crystal mush, may have a role to play in low volume peralkaline systems. Single-stage mush extraction models may not be rheologically compatible with high degrees of fractionation. Two-stage extraction models have the potential to greatly reduce the total volume of fusable crystal mush that is added to the crust, and which may then be cannibalized via remelting. The various magmatic systems of the Atlantic islands can be described using a three stage model, in which peralkaline felsic magmas are only able to form when a stable upper crustal magma reservoir is able to form. The onset of peralkaline magmatism is highly variable, with no clear link to the age of the respective magmatic system. Tectonic controls are also possible, with extension potentially facilitating the formation of upper crustal reservoirs in which magmas can stagnate and evolve, as may be the case in the Azores. Ultimately, the generation of peralkaline magmas is likely to be controlled by the magma flux rate of the magmatic system. If the flux is too low, an established magma reservoir in the cool, upper crust will cool and solidify. If the flux is too high, then the upper crustal reservoir will erupt before evolved magmas can form. Despite this, more than half of the Atlantic islands exhibit peralkaline rocks, suggesting that these conditions, although not inevitable, are common in the life cycle of the Atlantic Ocean island volcanoes.

\section{AUTHOR CONTRIBUTIONS}

The project was initially conceived by AJ and RG. The published data used by the study were collated by AJ. The manuscript, 
figures, and tables were jointly produced and subsequently revised by $\mathrm{AJ}$ and $\mathrm{RG}$.

\section{FUNDING}

This work was supported by Keele University.

\section{REFERENCES}

Abdel-Monem, A., Watkins, N., and Gast, P. (1971). Potassium-argon ages, volcanic stratigraphy, and geomagnetic polarity history of the Canary Islands; Lanzarote, Fuerteventura, Gran Canaria, and La Gomera. Am. J. Sci. 271, 490-521. doi: 10.2475/ajs.271.5.490

Abdel-Monem, A., Watkins, N., and Gast, P. (1972). Potassium-argon ages, volcanic stratigraphy and geomagnetic polarity history of the Canary Islands: Tenerife, La Palma and Hierro. Am. J. Sci. 272, 805-825. doi: 10.2475/ajs.272. 9.805

Abdel-Monem, A. A., Fernandez, L. A., and Boone, G. M. (1975). K-Ar ages from the eastern Azores group (Santa Maria, São Miguel and the Formigas islands). Lithos 8, 247-254. doi: 10.1016/0024-4937(75)90008-0

Ablay, G. J., Carroll, M. R., Palmer, M. R., Martí, J., and Sparks, R. S. J. (1998). Basanite-phonolite lineages of the Teide-Pico Viejo volcanic complex, Tenerife, Canary Islands. J. Petrol. 39, 905-936. doi: 10.1093/petroj/39. 5.905

Ablay, G. J., Ernst, G. G. J., Martí, J., and Sparks, R. S. J. (1995). The $\sim 2$ ka subplinian eruption of Montaña Blanca, Tenerife. Bull. Volcanol. 57, 337-355.

Acocella, V. (2014). Structural control of magmatism along divergent and convergent plate boundaries: Overview, model, problems. Earth Sci. Rev. 136, 226-288. doi: 10.1016/j.earscirev.2014.05.006

Aka, F. T., Nagao, K., Kusakabe, M., Sumino, H., Tanyileke, G., Ateba, B., et al. (2004). Symmetrical helium isotope distribution on the Cameroon volcanic line, West Africa. Chem. Geol. 203, 205-223. doi: 10.1016/j.chemgeo.2003. 10.003

Allen, R. M., Nolet, G., Morgan, W. J., Vogfjörd, K., Bergsson, B. H., Erlendsson, P., et al. (1999). The thin hot plume beneath Iceland. Geophys. J. Int. 137, 51-63. doi: 10.1046/j.1365-246x.1999.00753.x

Almeida, F. F. M. (1955). Geologia e Petrologia do Arquipélago de Fernando de Noronha. Rio de Janeiro: Servicão Grafico do Instituto Brasileiro de Geografia e Estatiìstica.

Almeida, F. F. M. (1961). Geologia e Petrologica da Ilha da Trindade. Rio de Janeiro: DNPM.

Almeida, F. F. M. (1963). Mapa Geológico da Ilha da Trindade. Rio de Janeiro: DNPM.

Almeida, F. F. M. (2012). "Ilhas ceânicas brasileiras," in Geologia do Brasil, eds Y. Hasui, C. D. R. Caqrneiro, F. F. M. Almeida, and A. Bartorelli (São Paulo: Beca), 658-662.

Ancochea, E., Fuster, J., Ibarrola, E., Cendrero, A., Coello, J., Hernan, F., et al. (1990). Volcanic evolution of the island of Tenerife (Canary Islands) in the light of new K-Ar data. J. Volcanol. Geother. Res. 44, 231-249. doi: 10.1016/03770273(90)90019-C

Ancochea, E., Huertas, M. J., Cantagrel, J. M., Coello, J., Fúster, J. M., Arnaud, N., et al. (1999). Evolution of the Cañadas edifice and its implications for the origin of the Cañadas Caldera (Tenerife, Canary Islands). J. Volcanol. Geother. Res. 88, 177-199. doi: 10.1016/S0377-0273(98)00106-1

Andújar, J., Costa, F., and Martí, J. (2010). Magma storage conditions of the last eruption of Teide volcano (Canary Islands, Spain). Bull. Volcanol. 72, 381-395. doi: 10.1007/s00445-009-0325-3

Andújar, J., Costa, F., Martí, J., Wolff, J. A., and Carroll, M. R. (2008). Experimental constraints on pre-eruptive conditions of phonolitic magma from the calderaforming El Abrigo eruption, Tenerife (Canary Islands). Chem. Geol. 257, 173-191. doi: 10.1016/j.chemgeo.2008.08.012

Andújar, J., Costa, F., and Scaillet, B. (2013). Storage conditions and eruptive dynamics of central versus flank eruptions in volcanic islands: the case

\section{ACKNOWLEDGMENTS}

An earlier form of this manuscript was greatly improved by the constructive and detailed reviews of F. Genske, J. Sliwinski, and T. Ubide. We are also very grateful to P. Larrea and V. Acocella for their insightful comments and editorial handling.

of Tenerife (Canary Islands, Spain). J. Volcanol. Geother. Res. 260, 62-79. doi: 10.1016/j.jvolgeores.2013.05.004

Annen, C., Pichavant, M., Bachmann, O., and Burgisser, A. (2008). Conditions for the growth of a long-lived shallow crustal magma chamber below Mount Pelee volcano (Martinique, Lesser Antilles Arc). J. Geophys. Res. Solid Earth 113:B7. doi: 10.1029/2007JB005049

Aparicio, A., Bustillo, M. A., Garcia, R., and Araña, V. (2006). Metasedimentary xenoliths in the lavas of the Timanfaya eruption. (1730-1736, Lanzarote, Canary Islands): metamorphism and contamination processes. Geol. Mag. 143, 181-193. doi: 10.1017/S0016756806001713

Aparicio, A., Tassinari, C. C., García, R., and Araña, V. (2010). Sr and Nd isotope composition of the metamorphic, sedimentary and ultramafic xenoliths of Lanzarote (Canary Islands): implications for magma sources. J. Volcanol. Geother. Res. 189, 143-150. doi: 10.1016/j.jvolgeores.2009.10.017

Araña, V., Marti, J., Aparicio, A., García-Cacho, L., and García- García, R. (1994). Magma mixing in alkaline magmas: an example from Tenerife, Canary Islands. Lithos 32, 1-19. doi: 10.1016/0024-4937(94)90018-3

Asavin, A. M., Kogarko, L. N., Kryuchkova, O. I., Tyurin, D. A., and Kolesov, G. M. (1997). Grand Canary, Saint Helena, and Tristan da Cunha Oceanic Islands: variations of trace element partition coefficients in pyroxene-melt equilibria during alkaline magma evolution. Geochem. Int. 35, $415-423$.

Atkins, F. B., Baker, P. E., Bell, J. D., and Smith, D. G. W. (1964). Oxford expedition to Ascension Island. Nature 204, 722-724. doi: 10.1038/204722a0

Aulinas, M., Gimeno, D., Fernandez-Turiel, J. L., Perez-Torrado, F. J., RodriguezGonzalez, A., and Gasperini, D. (2010). The Plio-Quaternary magmatic feeding system beneath Gran Canaria (Canary Islands, Spain): constraints from thermobarometric studies. J. Geol. Soc. London 167, 785-801. doi: 10.1144/ 0016-76492009-184

Avanzinelli, R., Bindi, L., Menchetti, S., and Conticelli, S. (2004). Crystallisation and genesis of peralkaline magmas from Pantelleria volcano, Italy: an integrated petrological and crystal-chemical study. Lithos 73, 41-69. doi: 10.1016/j.lithos. 2003.10.007

Bachmann, O., and Bergantz, G. W. (2004). On the origin of crystal-poor rhyolites: extracted from batholithic crystal mushes. J. Petrol. 45, 1565-1582. doi: 10.1093/ petrology/egh019

Bachmann, O., and Huber, C. (2016). Silicic magma reservoirs in the Earth's crust. Am. Mineral. 101, 2377-2404. doi: 10.1038/nature17401

Bailey, D. K. (1974). Experimental petrology relating to oversaturated peralkaline volcanics. A review. Bull. Volcanol. 38, 637-652. doi: 10.1007/BF02596901

Bailey, D. K., and Macdonald, R. (1970). Petrochemical variations among mildly peralkaline (comendite) obsidians from the oceans and continents. Contrib. Mineral. Petrol. 28, 340-351. doi: 10.1007/BF00388955

Bailey, D. K., and Macdonald, R. (1975). Fluorine and chlorine in peralkaline liquids and the need for magma generation in an open system. Mineral. Mag. 40, 405-414. doi: 10.1180/minmag.1975.040.312.10

Bailey, D. K., and Schairer, J. F. (1964). Feldspar-liquid equilibria in peralkaline liquids - the orthoclase effect. Am. J. Sci. 262, 1198-1206. doi: 10.2475/ajs.262. 10.1198

Bailey, J. C., Gwozdz, R., Rose-Hansen, J., and Sørensen, H. (2001). Geochemical overview of te Ilimaussaq alkaline complex, South Greenland. Geol. Greenland Surv. Bull. 190, 35-53.

Baker, B. H., and Henage, L. F. (1977). Compositional changes during crystallization of some peralkaline silicic lavas of the Kenya rift valley. J. Volcanol. Geother. Res. 2, 17-28. doi: 10.1016/0377-0273(77)90013-0

Baker, I. (1968). Intermediate oceanic volcanic rocks and the 'Daly Gap'. Earth Planet. Sci. Lett. 4, 103-106. doi: 10.1016/0012-821X(68)90002-2 
Baker, I. (1969). Petrology of the volcanic rocks of Saint Helena Island, South Atlantic. Geol. Soc. Am. Bull. 80, 1283-1310. doi: 10.1130/0016-7606(1969) 80[1283:POTVRO]2.0.CO;2

Baker, I., Gale, N. H., and Simons, J. (1967). Geochronology of the St. Helena volcanoes. Nature 215, 1451-1454. doi: 10.1038/2151451a0

Baker, P. E. (1974). Peralkaline acid volcanic rocks of oceanic islands. Bull. Volcanol. 38, 737-754. doi: 10.1007/BF02596906

Baker, P. E., Gass, I. G., Harris, P. G., and Le Maitre, R. W. (1964). The volcanological report of the Royal Society expedition to Tristan da Cunha, 1962. Philos. Trans. R. Soc. A 256, 439-575. doi: 10.1098/rsta.1964.0011

Baker, P. E., and Tomblin, J. F. (1964). A recent volcanic eruption on Bouvetøya, South Atlantic Ocean. Nature 203, 1055-1056. doi: 10.1038/2031055a0

Balogh, K., Ahijado, A., Casillas, R., and Fernandez, C. (1999). Contributions to the chronology of the Basal Complex of Fuerteventura, Canary Islands. J. Volcanol. Geother. Res. 90, 81-101. doi: 10.1016/S0377-0273(99)00008-6

Barclay, J., Carroll, M. R., Houghton, B. F., and Wilson, C. J. N. (1996). Pre-eruptive volatile content and degassing history of an evolving peralkaline volcano. J. Volcanol. Geother. Res. 74, 5-87. doi: 10.1016/S0377-0273(96)00058-3

Barker, A. K., Troll, V. R., Carracedo, J. C., and Nicholls, P. A. (2015). The magma plumbing system for the 1971 Teneguía eruption on La Palma, Canary Islands. Contrib. Mineral. Petrol. 170:21. doi: 10.1007/s00410-015-1207-7

Becerril, L., Ubide, T., Sudo, M., Martí, J., Galindo, I., Galé, C., et al. (2016). Geochronological constraints on the evolution of El Hierro (Canary Islands). J. Afr. Earth Sci. 113, 88-94. doi: 10.1016/j.jafrearsci.2015.10.012

Beier, C., Haase, K. M., and Hansteen, T. H. (2006). Magma evolution of the Sete Cidades volcano, São Miguel, Azores. J. Petrol. 47, 1375-1411. doi: 10.1093/ petrology/egl014

Beier, C., Mata, J., Stöckhert, F., Mattielli, N., Brandl, P. A., Madureira, P., et al. (2013). Geochemical evidence for melting of carbonated peridotite on Santa Maria Island, Azores. Contrib. Mineral. Petrol. 165, 823-841. doi: 10.1007/ s00410-012-0837-2

Bernth, U., Brousse, R., Frei, R., and Sørensen, H. (2002). The origin of phonolites and trachytes from the Col de Guéry area, le Mont-Dore, Massif Central, France. Matematisk Fysiske Medd. 50:61.

Bindeman, I., Gurenko, A., Carley, T., Miller, C., Martin, E., and Sigmarsson, O. (2012). Silicic magma petrogenesis in Iceland by remelting of hydrothermally altered crust based on oxygen isotope diversity and disequilibria between zircon and magma with implications for MORB. Terra Nova 24, 227-232. doi: 10.1111/ j.1365-3121.2012.01058.x

Bjarnason, I. T., Wolfe, C. J., Solomon, S. C., and Gudmundsson, G. (1996). Initial results from the ICEMELT experiment: body-wave delay times and shear-wave splitting across Iceland. Geophys. Res. Lett. 23, 459-462. doi: 10.1029/96GL00420

Black, S., Macdonald, R., and Kelly, M. R. (1997). Crustalorigin for peralkaline rhyolites from Kenya: evidence ffrom U-series disequilibria and Th-isotopes. J. Petrol. 38, 277-297. doi: 10.1093/petroj/38.2.277

Bohrson, W. A., and Reid, M. R. (1997). Genesis of silicic peralkaline volcanic rocks in an ocean island setting by crustal melting and open-system processes: socorro Island, Mexico. J. Petrol. 38, 1137-1166. doi: 10.1093/petroj/38.9.1137

Bohrson, W. A., Reid, M. R., Grunder, A. L., Heizler, M. T., Harrison, T. M., and Lee, J. (1996). Prolonged history of silicic peralkaline volcanism in the eastern Pacific Ocean. J. Geophys. Res. Solid Earth 101, 11457-11474. doi: 10.1029/ 96JB00329

Bongiolo, E. M., Pires, G. L. C., Geraldes, M. C., Santos, A. C., and Neumann, R. (2015). Geochemical modelling and Nd-Sr data links nephelinite-phonolite successions and xenoliths of Trindade Island (South Atlantic Ocean, Brazil). J. Volcanol. Geother. Res. 306, 58-73. doi: 10.1016/j.jvolgeores.2015.10.002

Bonin, B., Grelou-Orsini, C., and Vialette, Y. (1978). Age, origin and evolution of the anorogenic complex of Evisa (Corsica): a K-Li-Rb-Sr study. Contrib. Mineral. Petrol. 65, 425-432. doi: 10.1007/BF00372289

Booth, B., Croasdale, R., and Walker, G. P. L. (1978). A quantitative study of five thousand years of volcanism on São Miguel, Azores. Philos. Trans. R. Soc. London A Math. Phys. Sci. 288, 271-319.

Bottinga, Y., and Weill, D. (1972). The viscosity of magmatic silicate liquids: a model for calculation. Am. J. Sci. 272, 438-475. doi: 10.2475/ajs.272. 5.438

Bowen, N. L. (1928). The Evolution of Igneous Rocks. New York, NY: Dover, 332.
Brousse, R., and Varet, J. (1966). Les trachytes du Mont-Dore et du Cantal septentrional et leurs enclaves. Bull. Soc. Geol. France 8, 246-262.

Brown, R. J., Barry, T. L., Branney, M. J., Pringle, M. S., and Bryan, S. E. (2003). The Quaternary pyroclastic succession of southeast Tenerife, Canary Islands: explosive eruptions, related caldera subsidence, and sector collapse. Geol. Mag. 140, 265-288. doi: 10.1017/S0016756802007252

Brown, R. J., and Branney, M. J. (2004). Event-stratigraphy of a caldera-forming ignimbrite eruption on Tenerife: the 273 ka Poris Formation. Bull. Volcanol. 66, 392-416. doi: 10.1007/s00445-003-0321-y

Brum da Silveira, A., Madeira, J., Ramalho, R., Fonseca, P., Rodrigues, C., and Prada, S. (2010a). Carta Geológica da Ilha da Madeira na Escala de1:50000, Folha A, Technical Report. Funchal: Secretaria Regional do Ambiente e Recursos Naturais.

Brum da Silveira, A., Madeira, J., Ramalho, R., Fonseca, P., Rodrigues, C., and Prada, S. (2010b). Carta Geológica da Ilha da Madeira na Escala de1:50000, Folha B, Technical Report. Funchal: Secretaria Regional do Ambiente e Recursos Naturais.

Brum da Silveira, A., Madeira, J., Ramalho, R., Fonseca, P., Rodrigues, C., and Prada, S. (2010c). Notícia Explicativa da Carta Geológica da Ilha daMadeira na Escala de 1:50000, Technical Report. Funchal: Secretaria Regional do Ambiente e Recursos Naturais.

Bryan, G. M., Kumar, N., and Castro, P. J. (1972). "The north Brazilian Ridge and the extension of equatorial fracture zones into the continent," in Anais do XXVI Congresso Brasileiro de Geologia, Belém, 133-144.

Bryan, S. E. (2006). Petrology and geochemistry of the Quaternary calderaforming, phonolitic Granadilla eruption, Tenerife (Canary Islands). J. Petrol. 47, 1557-1589. doi: 10.1093/petrology/egl020

Bryan, S. E., Cas, R. A. F., and Martí, J. (2000). The 0.57 Ma plinian eruption of the Granadilla Member, Tenerife (Canary Islands): an example of complexity in eruption dynamics and evolution. J. Volcanol. Geother. Res. 103, 209-238. doi: 10.1016/S0377-0273(00)00225-0

Burke, K. (2001). Origin of the Cameroon Line of volcano-capped swells. J. Geol. 109, 349-362. doi: 10.1086/319977

Calvert, A. T., Moore, R. B., McGeehin, J. P., and Rodrigues da Silva, A. M. (2006). Volcanic history and ${ }^{40} \mathrm{Ar} /{ }^{39} \mathrm{Ar}$ and $14 \mathrm{C}$ geochronology of Terceira Island, Azores, Portugal. J. Volcanol. Geother. Res. 156, 103-115. doi: 10.1016/j. jvolgeores.2006.03.016

Campbell, R. (1914). Rocks from Gough Island, South Atlantic. Trans. R. Soc. Edinb. 50, 397-404. doi: 10.1017/\$0080456800035997

Carmichael, I. S. E. (1962). Pantelleritic liquids and their phenocrysts. Mineral. Mag. 33, 86-113. doi: 10.1180/minmag.1962.033.257.03

Carmichael, I. S. E. (1964). The petrology of Thingmuli, a Tertiary volcano in eastern Iceland. J. Petrol. 5, 435-460. doi: 10.1093/petrology/5.3.435

Carracedo, J. C. (1979). Paleomagnetismo e Historia Volcánica de Tenerife. Santa Cruz de Tenerife: Aula de Cultura de Tenerife, 82.

Carracedo, J. C., Badiola, E. R., Guillou, H., Paterne, M., Scaillet, S., Torrado, F. P., et al. (2007). Eruptive and structural history of Teide Volcano and rift zones of Tenerife, Canary Islands. Geol. Soc. Am. Bull. 119, 1027-1051. doi: 10.1130/B26087.1

Carracedo, J. C., Day, S., Guillou, H., Rodríguez Badiola, E., Canas, J. A., and Pérez Torrado, J. F. (1997). "Geochronological, structural and morphological constraints in the genesis and evolution of the Canary Islands," in Proceedings of the International Workshop on Immature Oceanic Islands, La Palma, $45-48$.

Carracedo, J. C., Day, S., Guillou, H., Rogríguez Badiola, E., Canas, J. A., and Pérez Torrado, F. J. (1998). Hotspot volcanism close to a passive continental margin: the Canary Islands. Geol. Mag. 135, 591-604. doi: 10.1017/S0016756898001447

Carracedo, J. C., Guillou, H., Nomade, S., Rodríguez-Badiola, E., Pérez-Torrado, F. J., Rodríguez-González, A., et al. (2011). Evolution of ocean-island rifts: the northeast rift zone of Tenerife, Canary Islands. Bull. Geol. Soc. Am. 123, 562-584. doi: 10.1130/B30119.1

Carracedo, J. C., Pérez, F. J., Ancochea, E., Meco, J., Hernán, F., Cubas, C. R., et al. (2002). "Cenozoic volcanism II: the Canary Islands," in The Geology of Spain, eds W. Gibbons and T. Moreno (London: The Geological Society of London), 439-472.

Cashman, K., and Sparks, R. S. J. (2013). How volcanoes work: a 25 year perspective. Geol. Society of Am. Bull. 125, 664-690. doi: 10.1130/B30720.1 
Cashman, K. V., and Giordano, G. (2014). Calderas and magma reservoirs. J. Volcanol. Geother. Res. 288, 25-45. doi: 10.1016/j.jvolgeores.2014.09.007

Cashman, K. V., Sparks, R. S., and Blundy, J. D. (2017). Vertically extensive and unstable magmatic systems: a unified view of igneous processes. Science 355, 1-9. doi: 10.1126/science.aag3055

Chaffey, D. J., Cliff, R. A., and Wilson, B. M. (1989). "Characterisation of the St Helena magma source," in Magmatism in the Ocean Basins, Vol. 42, eds A. D. Saunders and M. J. Norry (London: Geological Society of London), 257-276.

Chamberlain, K. J., Barclay, J., Preece, K., Brown, R. J., Davidson, J. P., and Eimf. (2016). Origin and evolution of silicic magmas at ocean islands: perspectives from a zoned fall deposit on Ascension Island, South Atlantic. J. Volcanol. Geother. Res. 327, 349-360. doi: 10.1016/j.jvolgeores.2016.08.014

Chauvel, C., Dia, A. N., Bulourde, M., Chabaux, F., Durand, S., Ildefonse, P., et al. (2005). Do decades of tropical rainfall affect the chemical compositions of basaltic lava flows in Mt Cameroon? J. Volcanol. Geother. Res. 141, 195-223. doi: 10.1016/j.jvolgeores.2004.10.008

Civetta, L., Antonio, M., Orsi, G., and Tilton, G. R. (1998). The geochemistry of volcanic rocks from Pantelleria Island, Sicily Channel: petrogenesis and characteristics of the mantle source region. J. Petrol. 39, 1453-1491. doi: 10. 1093/petroj/39.8.1453

Clay, P. L., Kelley, S. P., Sherlock, S. C., and Barry, T. L. (2011). Partitioning of excess argon between alkali feldspars and glass in a young volcanic system. Chem. Geol. 289, 12-30. doi: 10.1016/j.chemgeo.2011.07.005

Cliff, R. A., Baker, P. E., and Mateer, N. J. (1991). Geochemistry of inaccessible island volcanics. Chem. Geol. 92, 251-260. doi: 10.1016/0009-2541(91)90073-Z

Cooper, L. B., Bachmann, O., and Huber, C. (2015). Volatile budget of Tenerife phonolites inferred from textural zonation of S-rich haüyne. Geology 43, 423-426. doi: $10.1130 / \mathrm{G} 36505.1$

Cordani, U. G. (1970). Idade do vulcanismo no Atlântico Sul. Boletim IGA 1, 9-75. doi: 10.11606/issn.2316-9001.v1i0p09-75

Cousens, B. L., Spera, F. J., and Tilton, G. R. (1990). Isotopic patterns in silicic ignimbrites and lava flows of the Mogan and lower Fataga Formations, Gran Canaria, Canary Islands: temporal changes in mantle source composition. Earth Planet. Sci. Lett. 96, 319-335. doi: 10.1016/0012-821X(90)90010-U

Crisp, J. A., and Spera, F. J. (1987). Pyroclastic flows and lavas of the Mogan and Fataga formations, Tejeda volcano, Gran Canaria, Canary Islands: mineral chemistry, intensive parameters, and magma chamber evolution. Contrib. Mineral. Petrol. 96, 503-518. doi: 10.1007/BF01166695

Crough, S. T. (1982). Geoid anomalies over the Cape Verde Rise. Mar. Geophys. Res. 5, 263-271. doi: 10.1007/BF00305564

Crough, S. T., Morgan, W. J., and Hargraves, R. B. (1980). Kimberlites: their relation to mantle hot spots. Earth Planet. Sci. Lett. 50, 260-274. doi: 10.1016/ 0012-821X(80)90137-5

Czajkowski, M. (2002). Excursion guide 15: a geological tour of the islands of Madeira and Porto Santo. Geol. Today 18, 26-34. doi: 10.1046/j.1365-2451. 2002.00009.x

Daly, R. A. (1910). Origin of alkaline rocks. Geol. Soc. Am. Bull. 21, 87-118. doi: 10.1130/GSAB-21-87

Daly, R. A. (1925). The geology of Ascension Island. Proc. Am. Acad. Arts Sci. 60, 1-80. doi: $10.2307 / 25130043$

Darwin, C. (1845). Journal of Researches into the Natural History and Geology of the Various Countries Visited during the Voyage of HMS Beagle Round the World, 2nd Edn. London: John Murray, 324.

Dávila-Harris, P., Ellis, B. S., Branney, M. J., and Carrasco-Núñez, G. (2013). Lithostratigraphic analysis and geochemistry of a vitric spatter-bearing ignimbrite: the Quaternary Adeje Formation, Cañadas volcano, Tenerife. Bull. Volcanol. 75:722. doi: 10.1007/s00445-013-0722-5

Déruelle, B., Moreau, C., Nkoumbou, C., Kambou, R., Lisssom, J., Njonfang, E., et al. (1991). "The Cameroon Line: a review," in Magmatism in Extensional Structural Settings. The Phanerozoic African Plate, eds A. B. Kampunzu and R. Lubala (Berlin: Springer), 274-327. doi: 10.1007/978-3-642-73966-8_12

Déruelle, B., Ngounouno, I., and Demaiffe, D. (2007). The 'Cameroon Hot Line' (CHL): a unique example of active alkaline intraplate structure in both oceanic and continental lithospheres. Comptes Rendus Geosci. 339, 589-600. doi: 10.1016/j.crte.2007.07.007

Di Genova, D., Romano, C., Hess, K.-U., Vona, A., Poe, B. T., Giordano, D., et al. (2013). The rheology of peralkaline rhyolites from Pantelleria Island. J. Volcanol. Geother. Res. 249, 201-216. doi: 10.1016/j.jvolgeores.2012.10.017
Dingwell, D. B., Hess, K.-U., and Romano, C. (1998). Extremely fluid behaviour of hydrous peralkaline rhyolites. Earth Planet. Sci. Lett. 158, 31-38. doi: 10.1016/ S0012-821X(98)00046-6

Dingwell, D. B., Scarfe, C. M., and Cronin, D. J. (1985). The effect of fluorine on viscosities in the system Na2O-Al2O3-SiO2: implications for phonolites, trachytes and rhyolites. Am. Mineral. 70, 80-87.

D'Oriano, C., Landi, P., Pimentel, A., and Zanon, V. (2017). Magmatic processes revealed by anorthoclase textures and trace element modelling: the case of the Lajes Ignimbrite eruption (Terceira Island, Azores). J. Volcanol. Geother. Res. 347, 44-63. doi: 10.1016/j.jvolgeores.2017.08.012

Doucelance, R., Escrig, S., Moreira, M., Gariépy, C., and Kurz, M. D. (2003). Pb$\mathrm{Sr}-\mathrm{He}$ isotope and trace element geochemistry of the Cape Verde archipelago. Geochim. Cosmochim. Acta 67, 3717-3733. doi: 10.1016/S0016-7037(03) 00161-3

Dufek, J., and Bachmann, O. (2010). Quantum magmatism: magmatic compositional gaps generated by melt-crystal dynamics. Geology 38, 687-690. doi: $10.1130 / \mathrm{G} 30831.1$

Dyhr, C. T., and Holm, P. M. (2010). A volcanological and geochemical investigation of Boa Vista, Cape Verde Islands; $40 \mathrm{Ar} / 39$ Ar geochronology and field constraints. J. Volcanol. Geother. Res. 189, 19-32. doi: 10.1016/j.jvolgeores. 2009.10.010

Ebinger, C. J., and Casey, M. (2001). Continental breakup in magmatic provinces: an Ethiopian example. Geology 29, 527-530. doi: 10.1130/0091-7613(2001) 029<0527:CBIMPA > 2.0.CO;2

Edgar, C. J., Wolff, J. A., Nichols, H. J., Cas, R. A. F., and Mart? , J. (2002). A complex Quaternary ignimbrite-forming phonolitic eruption: the Poris member of the Diego Hernández Formation (Tenerife, Canary Islands). J. Volcanol. Geother. Res. 118, 99-130. doi: 10.1016/S0377-0273(02)00252-4

Edgar, C. J., Wolff, J. A., Olin, P. H., Nichols, H. J., Pittari, A., Cas, R. A. F., et al. (2007). The late Quaternary Diego Hernandez Formation, Tenerife: volcanology of a complex cycle of voluminous explosive phonolitic eruptions. J. Volcanol. Geother. Res. 160, 59-85. doi: 10.1016/j.jvolgeores.2006. 06.001

Eisele, S., Freundt, A., Kutterolf, S., Hansteen, T. H., Klügel, A., and Irion, I. M. (2016). Evolution of magma chambers generating the phonolitic Cão Grande Formation on Santo Antão, Cape Verde Archipelago. J. Volcanol. Geother. Res. 327, 436-448. doi: 10.1016/j.jvolgeores.2016.09.016

Eisele, S., Freundt, A., Kutterolf, S., Ramalho, R. S., Kwasnitschka, T., Wang, K.-L., et al. (2015). Stratigraphy of the Pleistocene, phonolitic Cão Grande Formation on Santo Antão, Cape Verde. J. Volcanol. Geother. Res. 301, 204-220. doi: 10.1016/j.jvolgeores.2015.03.012

Ericson, D. B., Fleming, R. H., LaMourie, M. J., Barnes, C. A., Namias, J., and Broadus, J. M. (2017). Atlantic Ocean. Chicago, IL: Encyclopaedia Britannica, inc.

Faugeres, J. C., Legigan, P., Maillet, N., and Latouche, C. (1989). Pelagic, turbiditic, and contouritic sequential deposits on the Cape Verde plateau (leg 108, site 659, Northwest Africa): sediment record during Neogene time. Proc. Ocean Drill. Program Sci. Results 108, 311-328. doi: 10.2973/odp.proc.sr.108. 138.1989

Feraud, G. (1981). Datations des Résaux de Dykes et de Roches Volcaniques Sous-Marines par les Methods K-Ar et 40Ar-39Ar. Utilisation des Dykes Comme Marqueurs de Paleocontraintes. Ph.D. thesis, University of Nice Sophia Antipolis, Nice, 146.

Feraud, G., Gastaud, J., Schmincke, H., Pritchard, G., Lietz, J., and Bleil, U. (1981). New K-Ar ages, chemical analyses and magnetic data of rocks from the islands of Santa Maria (Azores), Porto Santo and Madeira (Madeira archipelago) and Gran Canaria (Canary Islands). Bull. Volcanol. 44, 359-375. doi: 10.1007/ BF02600570

Ferguson, A. K. (1978). The crystallisation of pyroxenes and amphiboles in some alkaline rocks and the presence of a pyroxene compositional gap. Contrib. Mineral. Petrol. 67, 11-15. doi: 10.1007/BF00371628

Ferla, P., and Meli, C. (2006). Evidence of magma mixing in the 'Daly Gap' of alkaline suites: a case study from the enclaves of Pantelleria (Italy). J. Petrol. 47, 1467-1507. doi: 10.1093/petrology/egl015

Fernandes, R. M. S., Catalão, J., and Trota, A. N. (2018). “The contribution of spacegeodetic techniques to the understanding of the present-day geodynamics of the Azores triple junction," in Volcanoes of the Azores, eds U. Kueppers and C. Beier (Berlin: Springer), 57-69. doi: 10.1007/978-3-642-32226-6_4 
Ferreira, M., Macedo, C., and Ferreira, J. (1988). K-Ar geochronology in the Selvagens, Porto Santo and Madeira islands (Eastern Central Atlantic): a 30 m.y. spectrum of submarine and subaerial volcanism. Lunar Planet. Sci. Conf. 19:325.

Fitton, J. G. (1987). "The Cameroon line, West Africa: a comparison between oceanic and continental alkaline volcanism," in Alkaline Igneous Rocks. Geological Society Special Publications, Vol. 30, eds J. G. Fitton and B. G. J. Upton (London: The Geological Society of London), 273-291. doi: 10.1144/ GSL.SP.1987.030.01.13

Fitton, J. G. (2007). “The OIB paradox," in Plates, Plumes, and Planetary Processes. Geological Society of America Special Paper, Vol. 430, eds G. R. Foulger and D. M. Jurdy (Boulder, CO: Geological Society of America), 387-412.

Fitton, J. G., and Hughes, D. J. (1977). Petrochemistry of the volcanic rocks of the Island of Principe, Gulf of Guinea. Contrib. Mineral. Petrol. 64, 257-272. doi: 10.1007/BF00371757

Flude, S., Burgess, R., and McGarvie, D. W. (2008). Silicic volcanism at Ljósufjöll, Iceland: insights into evolution and eruptive history from $\mathrm{Ar}-\mathrm{Ar}$ dating. J. Volcanol. Geother. Res. 169, 154-175. doi: 10.1016/j.jvolgeores.2007.08.019

Fodor, R. V., Mukasa, S. B., and Sial, A. N. (1998). Isotopic and trace-element indications of lithospheric and asthenospheric components in Tertiary alkali basalts, northeastern Brazil. Lithos 43, 197-217. doi: 10.1016/S0024-4937(98) 00012-7

Freundt, A., and Schmincke, H.-U. (1995). Petrogenesis of rhyolite-trachyte-basalt composite ignimbrite P1, Gran Canaria, Canary Islands. J. Geophys. Res. 100, 455-474. doi: 10.1029/94JB02478

Frost, B. R., and Frost, C. D. (2008). A geochemical classification for feldspathic igneous rocks. J. Petrol. 49, 1955-1969. doi: 10.1093/petrology/egn054

Furman, T., Frey, F. A., and Meyer, P. S. (1992a). Petrogenesis of evolved basalts and rhyolites at Austurhorn, southeastern Iceland: the role of fractional crystallization. J. Petrol. 33, 1405-1445. doi: 10.1093/petrology/33.6.1405

Furman, T., Meyer, P. S., and Frey, F. (1992b). Evolution of Icelandic central volcanoes: evidence from the Austerhorn intrusion, southeastern Iceland. Bull. Volcanol. 55, 45-62. doi: 10.1007/BF00301119

Gale, N. H., Moorbath, S., Simons, J., and Walker, G. P. L. (1966). K-Ar ages of acid intrusive rocks from Iceland. Earth Planet. Sci. Lett. 1, 284-288. doi: 10.1016/0012-821X(66)90008-2

Gandino, A., Guidi, M., Merlo, C., Mete, L., Rossi, R., and Zan, L. (1985). Preliminary model of the Ribeira Grande geothermal field (Azores Islands). Geothermics 14, 91-105. doi: 10.1016/0375-6505(85)90096-3

Gardner, J. E., Rutherford, M., Carey, S., and Sigurdsson, H. (1995). Experimental constraints on pre-eruptive water contents and changing magma storage prior to explosive eruptions of Mount St Helens volcano. Bull. Volcanol. 57, 1-17. doi: 10.1007/BF00298703

Gass, I. G. (1967). Geochronology of the Tristan da Cunha group of islands. Geol. Mag. 104, 160-170. doi: 10.1017/S0016756800040620

Geldmacher, J., and Hoernle, K. (2000). The $72 \mathrm{Ma}$ geochemical evolution of the Madeira hotspot (eastern North Atlantic): recycling of Paleozoic ( $\leq 500 \mathrm{Ma}$ ) oceanic lithosphere. Earth Planet. Sci. Lett. 183, 73-92. doi: 10.1016/S0012821X(00)00266- 1

Geldmacher, J., Hoernle, K., van den Bogaard, P., Duggen, S., and Werner, R. (2005). New ${ }^{40} \mathrm{Ar} /{ }^{39} \mathrm{Ar}$ age and geochemical data from seamounts in the Canary and Madeira volcanic provinces: support for the mantle plume hypothesis. Earth Planet. Sci. Lett. 237, 85-101. doi: 10.1016/j.epsl.2005.04.037

Geldmacher, J., van den Bogaard, P., Hoernle, K., and Schmincke, H. U. (2000). The ${ }^{40} \mathrm{Ar} /{ }^{39} \mathrm{Ar}$ age dating of the Madeira Archipelago and the hotspot track (eastern North Atlantic). Geochem. Geophys. Geosyst. 1:1008. doi: 10.1029/ 1999GC000018

Gelman, S. E., Gutiérrez, F. J., and Bachmann, O. (2013). On the longevity of large upper crustal silicic magma reservoirs. Geology 41, 759-762. doi: 10.1130/ G34241.1

Genske, F. S., Beier, C., Haase, K. M., Turner, S. P., Krumm, S., and Brandl, P. A. (2013). Oxygen isotopes in the Azores islands: crustal assimilation recorded in olivine. Geology 41, 491-494. doi: 10.1130/G33911.1

Genske, F. S., Turner, S. P., Beier, C., and Schaefer, B. F. (2012). The petrology and geochemistry of lavas from the western Azores islands of Flores and Corvo. J. Petrol. 53, 1673-1708. doi: 10.1093/petrology/egs029

Gente, P., Dyment, J., Maia, M., and Goslin, J. (2003). Interaction between the MidAtlantic Ridge and the Azores hot spot during the last 85 Myr: emplacement and rifting of the hotspot derived plateaus. Geochem. Geophys. Geosyst. 4:8514. doi: 10.1029/2003GC000527

Gerlach, D. C., Stormer, J. C. Jr., and Mueller, P. A. (1987). Isotopic geochemistry of Fernando de Noronha. Earth Planet. Sci. Lett. 85, 129-144. doi: 10.1016/0012821X(87)90027-6

Gertisser, R., Self, S., Gaspar, J. L., Kelley, S. P., Pimentel, A., Eikenberg, J., et al. (2010). Ignimbrite stratigraphy and chronology on Terceira Island, Azores. Geol. Soc. Am. Spec. Paper 464, 133-154. doi: 10.1130/2010.2464(07)

Gibson, I. L. (1970). A pantelleritic welded ash-flow from the Ethiopian Rift Valley. Contrib. Mineral. Petrol. 28, 89-111. doi: 10.1007/BF00404992

Gioncada, A., and Landi, P. (2010). The pre-eruptive volatile contents of recent basaltic and pantelleritic magmas at Pantelleria (Italy). J. Volcanol. Geother. Res. 271, 123-201. doi: 10.1016/j.jvolgeores.2009.11.006

Giordano, D., Mangiacapra, A., Potuzak, M., Russell, J. K., Romano, C., Dingwell, D. B., et al. (2006). An expanded non-Arrhenian model for silicate melt viscosity: a treatment for metaluminous, peraluminous and peralkaline liquids. Chem. Geol. 229, 42-56. doi: 10.1016/j.chemgeo.2006.01.007

Giordano, D., Romano, C., Dingwell, D. B., Poe, B., and Behrens, H. (2004). The combined effects of water and fluorine on the viscosity of silicic magmas. Geochim. Cosmochim. Acta 68, 5159-5168. doi: 10.1016/j.gca.2004.08.012

González, P. J., Bagnardi, M., Hooper, A. J., Larsen, Y., Marinkovic, P., Samsonov, S. V., et al. (2015). The 2014-2015 eruption of Fogo volcano: Geodetic modelling of Sentinel-1 TOPS interferometry. Geophys. Res. Lett. 42, 92399246. doi: 10.1002/2015GL066003

Goodenough, K. M., Schilling, J., Jonsson, E., Kalvig, P., Charles, N., Tuduri, J., et al. (2016). Europe's rare earth element resource potential: an overview of REE metallogenetic provinces and their geodynamic setting. Ore Geol. Rev. 72, 838-856. doi: 10.1016/j.oregeorev.2015.09.019

Gudmundsson, A. (1995). Ocean-ridge discontinuities in Iceland. J. Geol. Soc. London 152, 1011-1015. doi: 10.1144/GSL.JGS.1995.152.01.22

Gudmundsson, A. (2000). Dynamics of volcanic systems in Iceland: example of tectonism and volcanism at juxtaposed hot spot and mid-ocean ridge systems. Annu. Rev. Earth Planet. Sci. 28, 107-140. doi: 10.1146/annurev.earth. 28.1.107

Guest, J. E., Gaspar, J. L., Cole, P. D., Queiroz, G., Duncan, A. M., Wallenstein, N., et al. (1999). Volcanic geology of Furnas volcano, São Miguel, Azores. J. Volcanol. Geother. Res. 92, 1-29. doi: 10.1016/S0377-0273(99)00064-5

Guillou, H., Carracedo, J. C., Torrado, F. P., and Badiola, E. R. (1996). K-Ar ages and magnetic stratigraphy of a hotspot-induced, fast grown oceanic island: El Hierro, Canary Islands. J. Volcanol. Geother. Res. 73, 141-155. doi: 10.1016/ 0377-0273(96)00021-2

Gunnarsson, B., Marsh, B., and Taylor, H. P. Jr. (1998). Generation of Icelandic rhyolites: silicic lavas from the Torfajökull central volcano. J. Volcanol. Geother. Res. 83, 1-45. doi: 10.1016/S0377-0273(98)00017-1

Haffty, J., and Noble, D. C. (1972). Release and migration of molybdenum during the primary crystallization of peralkaline silicic volcanic rocks. Econ. Geol. 67, 768-775. doi: 10.2113/gsecongeo.67.6.768

Hansteen, T. H., Klügel, A., and Schmincke, H. U. (1998). Multi-stage magma ascent beneath the Canary Islands: evidence from fluid inclusions. Contrib. Mineral. Petrol. 132, 48-64. doi: 10.1007/s004100050404

Hansteen, T. H., and Troll, V. R. (2003). Oxygen isotope composition of xenoliths from the oceanic crust and volcanic edifice beneath Gran Canaria (Canary Islands): consequences for crustal contamination of ascending magmas. Chem. Geol. 193, 181-193. doi: 10.1016/S0009-2541(02)00325-X

Hardarson, B. S., Fitton, J. G., Ellam, R. M., and Pringle, M. S. (1997). Rift relocation - a geochemical and geochronological investigation of a palaeo-rift in Northwest Iceland. Earth Planet. Sci. Lett. 153, 181-196. doi: 10.1016/S0012821X(97)00145-3

Hards, V. L., Kempton, P. D., Thompson, R. N., and Greenwood, P. B. (2000). The magmatic evolution of the Snæfell volcanic centre; an example of volcanism during incipient rifting in Iceland. J. Volcanol. Geother. Res. 99, 97-121. doi: 10.1016/S0377-0273(00)00160-8

Harris, C. (1983). The petrology of lavas and associated plutonic inclusions of Ascension Island. J. Petrol. 24, 424-470. doi: 10.1093/petrology/24.4.424

Harris, C., and Bell, J. D. (1982). Natural partial melting of syenite blocks from Ascension Island. Contrib. Mineral. Petrol. 79, 107-113. doi: 10.1007/ BF01132880 
Harris, C., Bell, J. D., and Atkins, F. B. (1982). Isotopic composition of lead and strontium in lavas and coarse-grained blocks from Ascension Island, South Atlantic. Earth Planet. Sci. Lett. 60, 79-85. doi: 10.1016/0012-821X(82) 90022-X

Harris, C., Smith, H. S., and le Roex, A. P. (2000). Oxygen isotope composition of phenocrysts from Tristan da Cunha and Gough Island lavas: variation with fractional crystallisation and evidence for assimilation. Contrib. Mineral. Petrol. 138, 164-175. doi: 10.1007/s004100050015

Hartley, M. E., Thordarson, T., and de Joux, A. (2016). Postglacial eruptive history of the Askja region, North Iceland. Bull. Volcanol. 78:28. doi: 10.1007/s00445016-1022-7

Hedberg, J. D. (1969). A Geological Analysis of the Cameroon Trend. Ph.D. thesis, Princeton University, Princeton, NJ, 188.

Heezen, B. C., and Tharp, M. (1961). Physiographic Diagram of the South Atlantic Ocean. Boulder: Geological Society of America.

Hicks, A., Barclay, J., Mark, D. F., and Loughlin, S. (2012). Tristan da Cunha: constraining eruptive behaviour using the ${ }^{40} \mathrm{Ar} /{ }^{39} \mathrm{Ar}$ dating technique. Geology 40, 723-726. doi: 10.1130/G33059.1

Hildenbrand, A., Madureira, P., Marques, F. O., Cruz, I., Henry, B., and Silva, P. (2008). Multi-stage evolution of a sub-aerial volcanic ridge over the last $1.3 \mathrm{Myr}$ : S. Jorge Island Azores Triple Junction. Earth Planet. Sci. Lett. 273, 289-298. doi: 10.1016/j.epsl.2008.06.041

Hildenbrand, A., Weis, D., Madureira, P., and Marques, F. O. (2014). Recent plate re-organization at the Azores Triple Junction: evidence from combined geochemical and geochronological data on Faial, S. Jorge and Terceira volcanic Islands. Lithos 210, 27-39. doi: 10.1016/j.lithos.2014.09.009

Hildner, E., Klügel, A., and Hansteen, T. H. (2012). Barometry of lavas from the 1951 eruption of Fogo, Cape Verde Islands: implications for historic and prehistoric magma plumbing systems. J. Volcanol. Geother. Res. 21, 73-90. doi: 10.1016/j.jvolgeores.2011.12.014

Hildner, E., Klügel, A., and Hauff, F. (2011). Magma storage and ascent during the 1995 eruption of Fogo, Cape Verde archipelago. Contrib. Mineral. Petrol. 162 751-772. doi: 10.1007/s00410-011-0623-6

Hildreth, W. (1981). Gradients in silicic magma chambers: implications for lithospheric magmatism. J. Geophys. Res. 86, 10153-10192. doi: 10.1029/ JB086iB11p10153

Hildreth, W. (2004). Volcanological perspectives on Long Valley, Mammoth Mountain, and Mono Craters: several contiguous but discrete systems. J. Volcanol. Geother. Res. 136, 169-198. doi: 10.1016/j.jvolgeores.2004. 05.019

Hoernle, K. (1998). Geochemistry of Jurassic oceanic crust beneath Gran Canaria (Canary Islands): implications for crustal recycling and assimilation. J. Petrol. 39, 859-880. doi: 10.1093/petroj/39.5.859

Hoernle, K., and Carracedo, J. C. (2009). "Canary Islands, geology," in Encyclopedia of Islands, eds R. G. Gillespie and D. A. Clague (Berkeley, CA: Press), 133-143.

Hofmann, A. W. (2003). Sampling mantle heterogeneity through oceanic basalts: isotopes and trace elements. Treatise Geochem. 2, 61-101.

Holm, P. M., Grandvuinet, T., Friis, J., Wilson, J. R., Barker, A. K., and Plesner, S. (2008). An ${ }^{40} \mathrm{Ar}-{ }^{39} \mathrm{Ar}$ study of the Cape Verde hot spot: temporal evolution in a semistationary plate environment. J. Geophys. Res. 113:B08201. doi: 10.1029/ 2007JB005339

Holm, P. M., Wilson, J. R., Christensen, B. P., Hansen, L., Hansen, S. L., Hein, K. M., et al. (2006). Sampling the Cape Verde mantle plume: evolution of melt compositions on Santo Antão, Cape Verde Islands. J. Petrol. 47, 145-189. doi: 10.1093/petrology/egi071

Huber, C., Bachmann, O., and Dufek, J. (2012). Crystal-poor versus crystalrich ignimbrites: a competition between stirring and reactivation. Geology 40, 115-118. doi: 10.1130/G32425.1

Imsland, P., Larsen, J. G., Prestvik, T., and Sigmond, E. M. (1977). The geology and petrology of Bouvetøya, south Atlantic Ocean. Lithos 10, 213-234. doi: 10.1016/0024-4937(77)90049-4

Jakobsson, S. P. (1979). Petrology of recent basalts of the Eastern Volcanic Zone, Iceland. Acta Naturalia Island. 26, 1-103.

Jeffery, A. J. (2016). Petrogenesis and Contrasting Eruption Styles of Peralkaline Silicic Magmas from Terceira and São Miguel, Azores. Ph.D. thesis, Keele University, Newcastle, 746 .

Jeffery, A. J., Gertisser, R., Jackson, R. A., O’Driscoll, B., and Kronz, A. (2016a). On the compositional variability of dalyite, $\mathrm{K} 2 \mathrm{ZrSi6O} 15$ : a new occurrence from Terceira, Azores. Mineral. Mag. 80, 547-565. doi: 10.1180/minmag.2016. 080.018

Jeffery, A. J., Gertisser, R., O’Driscoll, B., Pacheco, J. M., Whitley, S., Pimentel, A., et al. (2016b). Temporal evolution of a post-caldera, mildly peralkaline magmatic system: Furnas volcano, São Miguel, Azores. Contrib. Mineral. Petrol. 171:42. doi: 10.1007/s00410-016-1235-y

Jeffery, A. J., Gertisser, R., Self, S., Pimentel, A., O’Driscoll, B., and Pacheco, J. M. (2017). Petrogenesis of the peralkaline ignimbrites of Terceira, Azores. J. Petrol. 58, 2365-2402. doi: 10.1093/petrology/egy012

Jicha, B. R., Singer, B. S., and Valentine, M. J. (2013). ${ }^{40} \mathrm{Ar} /{ }^{39} \mathrm{Ar}$ geochronology of subaerial Ascension Island and a re-evaluation of the temporal progression of basaltic to rhyolitic volcanism. J. Petrol. 54, 2581-2596. doi: 10.1093/petrology/ egt058

Jóhannesson, H. (1980). Jardlagaskipan og próun rekbelta á Vesturlandi (Stratigraphy and evolution of rift zones in West Iceland). Náttúrufroedingurinn 50, 13-31.

Johnsen, O., Ferraris, G., Gault, R. A., Grice, J., Kampf, A. R., and Pekov, I. V. (2003). The nomenclature of eudialyte-group minerals. Can. Mineral. 41, 785794. doi: 10.2113/gscanmin.41.3.785

Johnson, C. L., Wijbrans, J. R., Constable, C. G., Gee, J., Staudigel, H., Tauxe, L., et al. (1998). ${ }^{40} \mathrm{Ar} /{ }^{39} \mathrm{Ar}$ ages and paleomagnetism of Sao Miguel lavas, Azores. Earth Planet. Sci. Lett. 160, 637-649. doi: 10.1016/S0012-821X(98)00117-4

Jónasson, K. (1994). Rhyolite volcanism in the Krafla central volcano, north-east Iceland. Bull. Volcanol. 56, 516-528. doi: 10.1007/BF00302832

Jónasson, K. (2007). Silicic volcanism in Iceland: composition and distribution within the active volcanic zones. J. Geodyn. 43, 101-117. doi: 10.1016/j.jog.2006. 09.004

Jónasson, K., Holm, P. M., and Pedersen, A. K. (1992). Petrogenesis of silicic rocks from the Króksfjördur central volcano, NW Iceland. J. Petrol. 33, 1345-1369. doi: 10.1093/petrology/33.6.1345

Jørgensen, J., and Holm, P. (2002). Temporal variation and carbonatite contamination in primitive ocean island volcanics from São Vicente, Cape Verde Islands. Chem. Geol. 192, 249-267. doi: 10.1016/S0009-2541(02)00198-5

Jutzeler, M., Schmincke, H. U., and Sumita, M. (2010). The incrementally-zoned Miocene Ayaguares ignimbrite (Gran Canaria, Canary Islands). J. Volcanol. Geother. Res. 196, 1-19. doi: 10.1016/j.jvolgeores.2010.07.002

Kar, A., Weaver, B., Davidson, J., and Colucci, M. (1998). Origin of differentiated volcanic and plutonic rocks from Ascension Island, South Atlantic Ocean. J. Petrol. 39, 1009-1024. doi: 10.1093/petroj/39.5.1009

Kaula, W. M. (1970). Earth's gravity field: relation to global tectonics. Science 169, 982-985. doi: 10.1126/science.169.3949.982

Kawabata, H., Hanyu, T., Chang, Q., Kimura, J., Nichols, A. R. L., and Tatsumi, Y. (2011). The petrology and geochemistry of St. Helena alkali basalts: evaluation of the oceanic crust-recycling model for HIMU OIB. J. Petrol. 52, 791-838. doi: 10.1093/petrology/egr003

Khomyakov, A. (1995). Mineralogy of Hyperagpaitic Alkaline Rocks. Oxford: Clarendon Press, 222.

Klingelhöfer, F., Minshull, T. A., Blackman, D. K., Harben, P., and Childers, V. (2001). Crustal structure of Ascension Island from wide-angle seismic data: implications for the formation of near-ridge volcanic islands. Earth Planet. Sci. Lett. 190, 41-56. doi: 10.1016/S0012-821X(01)00362-4

Klitgord, K. D., and Schouten, H. (1986). "Plate kinematics of the Central Atlantic," in The Geology of North America, The Western North Atlantic Region, Vol. M, eds P. R. Vogt and B. E. Tucholke (Boulder, CO: Geological Society of America), 351-378.

Klügel, A., Hansteen, T. H., and Galipp, K. (2005). Magma storage and underplating beneath Cumbre Vieja volcano, La Palma (Canary Islands). Earth Planet. Sci. Lett. 236, 211-226. doi: 10.1016/j.epsl.2005.04.006

Klügel, A., and Klein, F. (2006). Complex magma storage and ascent at embryonic submarine volcanoes from the Madeira archipelago. Geology 34, 337-340. doi: 10.1130/G22077.1

Kobberger, G., and Schmincke, H.-U. (1999). Deposition of rheomorphic ignimbrite D (Mogán Formation), Gran Canaria, Canary Islands, Spain. Bull. Volcanol. 60, 465-485. doi: 10.1007/s004450050246

Kogarko, L. N. (1980). Ore-forming potential of alkaline magmas. Lithos 26, 167-175. doi: 10.1016/0024-4937(90)90046-4

Kogarko, L. N. (2008). Characteristics of alkali magma differentiation at the Cape Verde Islands. Geochem. Int. 46, 1071-1080. doi: 10.1134/S0016702908110013 
Krause, D. C., and Watkins, N. D. (1970). North Atlantic crustal genesis in the vicinity of the Azores. Geophys. J. R. Astron. Soc. 19, 261-283. doi: 10.1111/j. 1365-246X.1970.tb06046.x

Kristjánsson, L. (1982). Geomagnetic polarity mapping in Icelandic lavas. Comparison with ocean-floor magnetic lineations. Earth Evol. Sci. 2, 126-129.

Kuritani, T., Yokoyama, T., Kitagawa, H., Kobayashi, K., and Nakamura, E. (2011). Geochemical evolution of historical lavas from Askja Volcano, Iceland: implications for mechanisms and timescales of magmatic differentiation. Geochim. Cosmochim. Acta 75, 570-587. doi: 10.1016/j.gca.2010.10.009

Lacasse, C., Sigurdsson, H., Carey, S. N., Jóhannesson, H., Thomas, L. E., and Rogers, N. W. (2007). Bimodal volcanism at the Katla subglacial caldera, Iceland: insight into the geochemistry and petrogenesis of rhyolitic magmas. Bull. Volcanol. 69:373. doi: 10.1007/s00445-006-0082-5

Lange, R. A. (1994). "The effect of $\mathrm{H}_{2} \mathrm{O}, \mathrm{CO}_{2}$ and $\mathrm{F}$ on the density and viscosity of silicate melts," in Volatiles in Magmas, Vol. 30, eds M. R. Carroll and J. R. Holloway (Chantilly, VA: Mineralogical Society of America), 331-365.

Larrea, P., França, Z., Lago, M., Widom, E., Galé, C., and Ubide, T. (2013). Magmatic processes and the role of antecrysts in the genesis of Corvo island (Azores archipelago), Portugal. J. Petrol. 54, 769-793. doi: 10.1093/petrology/ egs084

Larrea, P., França, Z., Widom, E., and Lago, M. (2018). "Petrology of the Azores Islands," in Volcanoes of the Azores, eds U. Kueppers and C. Beier (Berlin: Springer), 197-249. doi: 10.1007/978-3-642-32226-6_10

Larrea, P., Galé, C., Ubide, T., Widom, E., Lago, M., and França, Z. (2014a). Magmatic evolution of Graciosa (Azores), Portugal. J. Petrol. 55, 2125-2154. doi: 10.1093/petrology/egu052

Larrea, P., Wijbrans, J. R., Galé, C., Ubide, T., Lago, M., França, Z., et al. (2014b). ${ }^{40} \mathrm{Ar} /{ }^{39} \mathrm{Ar}$ constraints on the temporal evolution of Graciosa Island, Azores (Portugal). Bull. Volcanol. 76:796. doi: 10.1007/s00445-014-0796-8

Larsen, G., Newton, A. J., Dugmore, A. J., and Vilmundardottir, E. G. (2001). Geochemistry, dispersal, volumes and chronology of Holocene silicic tephra layers from the Katla volcanic system, Iceland. J. Quaternary Sci. 16, 119-132. doi: 10.1002/jqs.587

Larsen, L. M. (1979). Distribution of REE and other trace elements between phenocrysts and peralkaline undersaturated magmas, exemplified by rocks from the Gardar igneous province, south Greenland. Lithos 12, 303-315. doi: 10.1016/0024-4937(79)90022-7

Le Bas, M. J., Le Maitre, R. W., Streckeisen, A., and Zanettin, B. (1986). A chemical classification of volcanic rocks based on the total alkali-silica diagram. J. Petrol. 27, 745-750. doi: 10.1093/petrology/27.3.745

Le Maitre, R. W. (1962). Petrology of volcanic rocks, Gough Island, South Atlantic. Geol. Soc. Am. Bull. 73, 1309-1340. doi: 10.1130/0016-7606(1962)73[1309: POVRGI]2.0.CO;2

Le Maitre, R. W. (2003). International A Classification of Igneous Rocks and Glossary of Terms: Recommendations of the International Union of Geological Sciences Subcommission on the Systematics of Igneous Rocks. Oxford: Blackwell Scientific Publications, 193.

Le Roex, A. P. (1985). Geochemistry, mineralogy, and magmatic evolution of the basaltic and trachytic lavas from Gough Island, South Atlantic. J. Petrol. 26, 149-186. doi: 10.1093/petrology/26.1.149

Le Roex, A. P., Cliff, R. A., and Adair, B. J. I. (1990). Tristan da Cunha, South Atlantic: geochemistry and petrogenesis of a basanite-phonolite lava series. J. Petrol. 31, 779-812. doi: 10.1093/petrology/31.4.779

Le Roex, A. P., Dick, H. J. B., Reid, A. M., Frey, F. A., Erlank, A. J., and Hart, S. R. (1985). Petrology and geochemistry of basalts from the AmericanAntarctic Ridge, Southern Ocean: implications for the westward influence of the Bouvet mantle plume. Contrib. Mineral. Petrol. 90, 367-380. doi: 10.1007/BF003 84715

Le Roex, A. P., and Erlank, A. J. (1982). Quantitative evaluation of fractional crystallisation in Bouvet Island lavas. J. Volcanol. Geother. Res. 13, 309-338. doi: 10.1016/0377-0273(82)90055-5

Leat, P. T. (1984). Geological evolution of the trachytic caldera volcano Menengai, Kenya Rift Valley. J. Geol. Soc. London 141, 1057-1069. doi: 10.1144/gsjgs.141. 6.1057

Lee, D. C., Halliday, A. N., Fitton, G. J., and Poli, G. (1994). Isotopic variations with distance and time in the volcanic islands of the Cameroon Line: evidence of the mantle plume origin. Earth Planet. Sci. Lett. 123, 119-138. doi: 10.1016/0012821X(94)90262-3
Lindhuber, M. J., Marks, M. A., Bons, P. D., Wenzel, T., and Markl, G. (2015). Crystal mat-formation as an igneous layering-forming process: textural and geochemical evidence from the 'lower layered' nepheline syenite sequence of the Ilímaussaq complex, South Greenland. Lithos 224, 295-309. doi: 10.1016/j. lithos.2015.03.007

Longpré, M. A., Klügel, A., Diehl, A., and Stix, J. (2014). Mixing in mantle magma reservoirs prior to and during the 2011-2012 eruption at El Hierro, Canary Islands. Geology 42, 315-318. doi: 10.1130/G35165.1

Lopes, R. P. (2002). O vulcanismo do Arquipélago de Fernando de Noronha, PE: Química Mineral e Geoquímica. Ph.D. thesis, Universidade de São Paulo, São Paulo.

Lopes, R. P., and Ulbrich, M. N. C. (2015). Geochemistry of the alkaline volcanic-subvolcanic rocks of the Fernando de Noronha archipelago, southern Atlantic Ocean. Braz. J. Geol. 45, 307-333. doi: 10.1590/231748892015000 20009

Lopes, R. P., Ulbrich, M. N. C., and Ulbrich, H. (2014). The subvolcanic rocks of the Fernando de Noronha archipelago, southern Atlantic Ocean: mineral chemistry. Central Eur. J. Geosci. 6, 422-456. doi: 10.2478/s13533-012-0195-7

Lowenstern, J. B. (1994). Chlorine, fluid immiscibility, and degassing in peralkaline magmas from Pantelleria, Italy. Am. Mineral. 79, 353-369.

Luis, J. F., Miranda, J. M., Galdeano, A., Patriat, P., Rossignol, J. C., and Mendes Victor, L. A. (1994). The Azores triple junction evolution since $10 \mathrm{Ma}$ from an aeromagnetic survey of the Mid-Atlantic Ridge. Earth Planet. Sci. Lett. 125, 439-459. doi: 10.1016/0012-821X(94)90231-3

Lunde, T. (1965). Fra et besøk på Bouvetøya. Norsk Polarinstitutt Årbok 1963, 197-203.

Macdonald, R. (1974a). Nomenclature and petrochemistry of the peralkaline oversaturated extrusive rocks. Bull. Volcanol. 38, 495-505.

Macdonald, R. (1974b). Tectonic settings and magma associations. Bull. Volcanol. 38, 575-593. doi: 10.1007/BF02596899

Macdonald, R. (2012). Evolution of peralkaline silicic complexes: lessons from the extrusive rocks. Lithos 152, 11-22. doi: 10.1016/j.lithos.2012.01.014

Macdonald, R., Bagiñski, B., Leat, P. T., White, J. C., and Dzierżanowski, P. (2011). Mineral stability in peralkaline silicic rocks: information from trachytes of the Menengai volcano, Kenya. Lithos 125, 553-568. doi: 10.1016/j.lithos.2011.03. 011

Macdonald, R., Bagiñski, B., Ronga, F., Dzierżanowski, P., Lustrini, M., Marzoli, A., et al. (2012). Evidence for extreme fractionation of peralkaline silicic magmas, the Boseti volcanic complex, Main Ethiopian Rift. Mineral. Petrol. 104, 163-175. doi: 10.1007/s00710-011-0184-4

Macdonald, R., Belkin, H. E., Fitton, J. G., Rogers, N. W., Nejbert, K., Tindle, A. G., et al. (2008). The roles of fractional crystallisation, magma mixing, crystal mush remobilisation, and volatile-melt interactions in the genesis of a young basaltperalkaline rhyolite suite, the Greater Olkaria Volcanic Complex, Kenya Rift Valley. J. Petrol. 49, 1515-1547. doi: 10.1093/petrology/egn036

Macdonald, R., Davies, G. R., Upton, B. G. J., Dunkley, P. N., Smith, M., and Leat, P. T. (1995). Petrogenesis of Silali volcano, Gregory Rift, Kenya. J. Geol. Soc. London 152, 703-720. doi: 10.1144/gsjgs.152.4.0703

Macdonald, R., McGarvie, D. W., Pinkerton, H., Smith, R. L., and Palacz, A. (1990). Petrogenetic evolution of the Torfajökull Volcanic Complex, Iceland I. Relationship between the magma types. J. Petrol. 31, 429-459. doi: 10.1093/ petrology/31.2.429

Macdonald, R., Navarro, J. M., Upton, B. G. J., and Davies, G. R. (1994). Strong compositional zonation in peralkaline magma: Menengai, Kenya Rift Valley. J. Volcanol. Geother. Res. 60, 301-325. doi: 10.1016/0377-0273(94)90057-4

Macdonald, R., and Scaillet, B. (2006). The central Kenya peralkaline province: insights into the evolution of peralkaline salic magmas. Lithos 91, 59-73. doi: 10.1016/j.lithos.2006.03.009

Macdonald, R., Sparks, R. S. J., and Sigurdsson, H. (1987). The 1875 eruption of Askja volcano, Iceland: combined fractional crystallization and selective contamination in the generation of rhyolitic magma. Mineral. Mag. 51, 183202. doi: 10.1180/minmag.1987.051.360.01

Madeira, J., Mata, J., Mourão, C., da Silveira, A. B., Martins, S., Ramalho, R., et al. (2010). Volcano-stratigraphic and structural evolution of Brava Island (Cape Verde) based on ${ }^{40} \mathrm{Ar} /{ }^{39} \mathrm{Ar}$, U-Th and field constraints. J. Volcanol. Geother. Res. 196, 219-235. doi: 10.1016/j.jvolgeores.2010.07.010

Madureira, P., Mata, J., Mattielli, N., Queiroz, G., and Silva, P. (2011). Mantle source heterogeneity, magma generation and magmatic evolution at Terceira 
Island (Azores archipelago): constraints from elemental and isotopic ( $\mathrm{Sr}, \mathrm{Nd}$, $\mathrm{Hf}$, and $\mathrm{Pb}$ ) data. Lithos 126, 402-418. doi: 10.1016/j.lithos.2011.07.002

Mahood, G. A., and Baker, D. R. (1986). Experimental constraints on depths of fractionation of mildly alkali basalts and associated felsic rocks: Pantelleria, Strait of Sicily. Contrib. Mineral. Petrol. 93, 251-264. doi: 10.1007/ BF00371327

Mahood, G. A., and Hildreth, W. (1986). Geology of the peralkaline volcano at Pantelleria, Strait of Sicily. Bull. Volcanol. 48, 143-172. doi: 10.1007/ BF01046548

Manning, D. A. C. (1981). The effect of fluorine on liquidus phase relationships in the system Qz-Ab-Or with excess water. Contrib. Mineral. Petrol. 76, 206-215. doi: 10.1007/BF00371960

Markl, G. (2001). A new type of silicate liquid immiscibility in peralkaline nepheline syenites (lujavrites) of the Ilimaussaq complex, South Greenland. Contrib. Mineral. Petrol. 141, 458-472. doi: 10.1007/s004100100252

Markl, G., Marks, M. A., and Frost, B. R. (2010). On the controls of oxygen fugacity in the generation and crystallization of peralkaline melts. J. Petrol. 51, 1831-1847. doi: 10.1093/petrology/egq040

Marks, M. A. W., Hettmann, K., Schilling, J., Frost, B. R., and Markl, G. (2011). The mineralogical diversity of alkaline igneous rocks: critical factors for the transition from miaskitic to agpaitic phase assemblages. J. Petrol. 52, 439-455. doi: 10.1093/petrology/egq086

Marks, M. A. W., and Markl, G. (2015). “The ilímaussaq alkaline complex, South Greenland," in Layered Intrusions, eds B. Charlier, O. Namur, R. Latypov, and C. Tegner (Dordrecht: Springer), 649-691.

Marks, M. A. W., and Markl, G. (2017). A global review on agpaitic rocks. Earth Sci. Rev. 173, 229-258. doi: 10.1016/j.earscirev.2017.06.002

Marques, F. O., Catalão, J. C., DeMets, C., Costa, A. C. G., and Hildenbrand, A. (2013). GPS and tectonic evidence for a diffuse plate boundary at the Azores triple junction. Earth Planet. Sci. Lett. 281, 177-187. doi: 10.1016/j.epsl.2013.08. 051

Marques, L. S., Ulbrich, M. N. C., Ruberti, E., and Tassinari, C. G. (1999). Petrology, geochemistry and Sr-Nd isotopes of the Trindade and Martin Vaz volcanic rocks (Southern Atlantic Ocean). J. Volcanol. Geother. Res 93, 191-216. doi: 10.1016/S0377-0273(99)00111-0

Marshall, A. S., Macdonald, R., Rogers, N. W., Fitton, J. G., Tindle, A. G., Nejbert, K., et al. (2009). Fractionation of peralkaline silicic magmas: the Greater Olkaria Volcanic Complex, Kenya Rift Valley. J. Petrol. 50, 323-359. doi: 10.1093/petrology/egp001

Martí, J., and Gudmundsson, A. (2000). The Las Cañadas caldera (Tenerife, Canary Islands): an overlapping collapse caldera generated by magma-chamber migration. J. Volcanol. Geother. Res. 103, 161-173. doi: 10.1016/S0377-0273(00) 00221-3

Martí, J., Mitjavila, J., and Araña, V. (1994). Stratigraphy, structure and geochronology of the Las Cañadas caldera (Tenerife, Canary Islands). Geol. Mag. 131, 715-727. doi: 10.1017/S0016756800012838

Martin, E., and Sigmarsson, O. (2007). Crustal thermal state and origin of silicic magma in Iceland: the case of Torfajökull, Ljósufjöll and Snæfellsjökull volcanoes. Contrib. Mineral. Petrol. 153, 593-605. doi: 10.1007/s00410-006$0165-5$

Martin, E., and Sigmarsson, O. (2010). Thirteen million years of silicic magma production in Iceland: links between petrogenesis and tectonic settings. Lithos 116, 129-144. doi: 10.1016/j.lithos.2010.01.005

Martin, V. M., Morgan, D. J., Jerram, D. A., Caddick, M. J., Prior, D. J., and Davidson, J. P. (2008). Bang! Month-scale eruption triggering at Santorini volcano. Science 321, 1178-1178. doi: 10.1126/science.1159584

Marzoli, A., Peccirillo, E. M., Renne, P. R., Bellieni, G., Iacumin, M., Nyobe, J. B., et al. (2000). The Cameroon Volcanic Line revisited: petrogenesis of continental basaltic magmas from lithospheric and asthenospheric mantle sources. J. Petrol. 41, 87-109. doi: 10.1093/petrology/41.1.87

Masotta, M., Mollo, S., Freda, C., Gaeta, M., and Moore, G. (2013). Clinopyroxeneliquid thermometers and barometers specific to alkaline differentiated systems. Contrib. Mineral. Petrol. 166, 1545-1561. doi: 10.1007/s00410-0130927-9

Mata, J., Martins, S., Mattielli, N., Madeira, J., Faria, B., Ramalho, R. S., et al. (2017). The 2014-15 eruption and the short-term geochemical evolution of the Fogo volcano (Cape Verde): evidence for small scale mantle heterogeneity. Lithos 288-289, 91-107. doi: 10.1016/j.lithos.2017.07.001
Matthews, N. E., Pyle, D. M., Smith, V. C., Wilson, C. J. N., Huber, C., and Van Hinsberg, V. (2012). Quartz zoning and the pre-eruptive evolution of the 340ka Whakamaru magma systems, New Zealand. Contrib. Mineral. Petrol. 163, 87-107. doi: 10.1007/s00410-011-0660-1

Maund, J. G., Rex, D. C., Le Roex, A. P., and Reid, D. L. (1988). Volcanism on Gough Island: a revised stratigraphy. Geol. Mag. 125, 175-181. doi: 10.1017/ S0016756800009572

Mbowou, I. B. G., Nguihdama, D., Yamgouot, F. N., Ntoumbe, M., and Ngounouno, I. (2013). Ti-bearing aenigmatite from Djinga Tadorgal (Adamawa plateau) and Sao Tomé (Cameroon Line) phonolites: geochemical implications and application of the QUILF thermobarometer for the crystallisation conditions. Int. J. Biol. Chem. Sci. 7, 2600-2610. doi: 10.4314/ijbcs.v7i6.34

McDougall, I., Kristjansson, L., and Saemundsson, K. (1984). Magnetostratigraphy and geochronology of NW-Iceland. J. Geophys. Res. 89, 7029-7060. doi: 10. 1029/JB089iB08p07029

McDougall, I., and Ollier, C. D. (1982). Potassium-argon ages from Tristan da Cunha, South Atlantic. Geol. Mag. 119, 87-93. doi: $10.1017 /$ S0016756800025681

McDougall, I., and Schmincke, H.-U. (1976). Geochronology of Gran Canaria, Canary Islands: age of shield building volcanism and other magmatic phases. Bull. Volcanol. 40, 57-77. doi: 10.1007/BF02599829

McGarvie, D. W. (1984). Torfajokull: a volcano dominated by magma mixing. Geology 12, 685-688. doi: 10.1130/0091-7613(1984)12<685:TAVDBM>2.0.CO; 2

McGarvie, D. W., Burgess, R., Tindle, A. G., Tuffen, H., and Stevenson, J. A. (2006). Pleistocene rhyolitic volcanism at Torfajökull, Iceland: eruption ages, glaciovolcanism, and geochemical evolution. Jökull 56, 57-75.

McGarvie, D. W., Macdonald, R., Pinkerton, H., and Smith, R. L. (1990). Petrogenetic evolution of the Torfajökull volcanic complex, Iceland II. The role of magma mixing. J. Petrol. 31, 461-481. doi: 10.1093/petrology/31. 2.461

McNutt, M. (1988). Thermal and mechanical properties of the Cape Verde Rise. J. Geophys. Res. Solid Earth 93, 2784-2794. doi: 10.1029/JB093iB04 p02784

Meletlidis, S., Di Roberto, A., Pompilio, M., Bertagnini, A., Iribarren, I., Felpeto, A., et al. (2012). Xenopumices from the 2011-2012 submarine eruption of El Hierro (Canary Islands, Spain): constraints on the plumbing system and magma ascent. Geophys. Res. Lett. 39, L17302. doi: 10.1029/2012GL052675

Merlino, S., and Perchiazzi, N. (1988). Modular mineralogy in the cuspidine group of minerals. Can. Mineral. 26, 933-943.

Métrich, N., Zanon, V., Créon, L., Hildenbrand, A., Moreira, M., and Marques, F. O. (2014). Is the 'Azores hotspot'a wetspot? Insights from the geochemistry of fluid and melt inclusions in olivine of Pico basalts. J. Petrol. 55, 377-393. doi: 10.1093/petrology/egt071

Mitchell-Thomé, R. C. (1970). Geology of the South Atlantic Islands. Berlin: Bebruder Borntraeger.

Mollo, S., Masotta, M., Forni, F., Bachmann, O., De Astis, G., Moore, G., et al. (2015). A K-feldspar-liquid hygrometer specific to alkaline differentiated magmas. Chem. Geol. 392, 1-8. doi: 10.1016/j.chemgeo.2014.11.010

Moorbath, S., Sigurdson, H., and Goodwin, R. (1968). K-Ar ages of oldest exposed rocks in Iceland. Earth Planet. Sci. Lett. 4, 197-205. doi: 10.1016/0012-821X(68) 90035-6

Moore, R. (1990). Volcanic geology and eruption frequency, São Miguel, Azores. . Bull. Volcanol. 52, 602-614. doi: 10.1007/BF00301211

Morgan, W. J. (1972). Deep mantle convection plumes and plate motions. Bull. Am. Associat. Petrol. Geol. 56, 203-213. doi: 10.1038/nature17422

Morgan, W. J. (1981). "Hotspot tracks and the opening of the Atlantic and Indian Oceans," in The Sea: Oceanic Lithosphere, Vol. 7, ed. C. Emiliani (New York, NY: John Wiley \& Sons), 443-487.

Moundi, A., Wandji, P., Bardintzeff, J.-M., Ménard, J.-J., Atouba, L. C. O., Mouncherou, O. F., et al. (2007). Les basaltes éocènes à affinité transitionnelle du plateau Bamoun, témoins d'un réservoir mantellique enrichi sous la ligne volcanique du Cameroun. Comptes Rendus Geosci. 339, 396-406. doi: 10.1016/ j.crte.2007.04.001

Mourão, C., Mata, J., Doucelance, J., Maderia, J., Brum da Silveira, A., Silva, L., et al. (2010). Quaternary extrusive calciocarbonatite volcanism on Brava Island, (Cape Verde). J. Afr. Earth Sci. 56, 59-74. doi: 10.1016/j.jafrearsci.2009. 06.003 
Mourão, C., Mata, J., Doucelance, R., Madeira, J., Millet, M. A., and Moreira, M. (2012). Geochemical temporal evolution of Brava Island magmatism: constraints on the variability of Cape Verde mantle sources and on carbonatitesilicate magma link. Chem. Geol. 334, 44-61. doi: 10.1016/j.chemgeo.2012.09. 031

Müller, R. D., Sdrolias, M., and Roest, W. R. (2008). Age, spreading rates and spreading symmetry of the world's oceanic crust. Geochem. Geophys. Geosyst. 9, 1525-2027. doi: 10.1029/2007GC001743

Mungall, J. E. (1993). Compositional effects of Magma Mixing and Diffusive Mass Transport on a Basalt-Pantellerite Suite, Terceira, Azores. Ph.D. thesis, McGill University, Montreal, 385.

Mungall, J. E., and Martin, R. F. (1995). Petrogenesis of basalt-comendite and basalt-pantellerite suites, Terceira, Azores, and some implications for the origin of ocean-island rhyolites. Contrib. Mineral. Petrol. 119, 43-55. doi: 10.1007/ BF00310716

Muñoz, M., Sagredo, J., de Ignacio, C., Fernández-Suárez, J., and Jeffries, T. E. (2005). New data (U-Pb, K-Ar) on the geochronology of the alkalinecarbonatitic association of Fuerteventura, Canary Islands, Spain. Lithos 85, 140-153. doi: 10.1016/j.lithos.2005.03.024

Neave, D. A., Fabbro, G., Herd, R. A., Petrone, C. M., and Edmonds, M. (2012). Melting, differentiation and degassing at the Pantelleria volcano, Italy. J. Petrol. 53, 637-663. doi: 10.1093/petrology/egr074

Neumann, E.-R., Olsen, K. H., Baldridge, W. S., and Sundvoll, B. (1992). The Oslo Rift: a review. Tectonphysics 208, 1-18. doi: 10.1016/0040-1951(92)90333-2

Neumann, E.-R., Wulff-Pedersen, E., Simonsen, S. L., Pearson, N. J., Martí, J., and Mitjavila, J. (1999). Evidence for fractional crystallisation of periodically refilled magma chambers in Tenerife, Canary Islands. J. Petrol. 40, 1089-1123. doi: $10.1093 /$ petroj/40.7.1089

Nicholls, J., and Carmichael, J. S. E. (1969). Peralkaline acid liquids: a petrological study. Contrib. Mineral. Petrol. 20, 268-294. doi: 10.1007/BF00377480

Nicholson, H., Condomines, M., Fitton, J. G., Fallick, A. E., Grönvold, K., and Rogers, G. (1991). Geochemical and isotopic evidence for crustal assimilation beneath Krafla, Iceland. J. Petrol. 32, 1005-1020. doi: 10.1093/petrology/32.5. 1005

Nielsen, S. G., Rehkämper, M., Brandon, A. D., Norman, M. D., Turner, S., and O'Reilly, S. Y. (2007). Thallium isotopes in Iceland and Azores lavas implications for the role of altered crust and mantle geochemistry. Earth Planet. Sci. Lett. 264, 332-345. doi: 10.1016/j.epsl.2007.10.008

Nielson, D. L., and Sibbett, B. S. (1996). Geology of ascension Island, South Atlantic Ocean. Geothermics 25, 427-448. doi: 10.1016/0375-6505(96)00018-1

Novak, S. W., and Mahood, G. A. (1986). Rise and fall of a basalt-trachyte-rhyolite magma system at the Kane Springs Wash Caldera, Nevada. Contrib. Mineral. Petrol. 94, 352-373. doi: 10.1007/BF00371444

Nystuen, J. P. (1975). Plutonic and subvolcanic intrusions in the Hurdal area, Oslo region. Norges Geol. Undersok. Bull. 317, 1-21.

O'Connor, J. M., and Duncan, R. A. (1990). Evolution of the Walvis Ridge - Rio Grande Rise hot spot system: implications for African and South American plate motions over plumes. J. Geophys. Res. 95, 17475-17502. doi: 10.1029/ JB095iB11p17475

Óskarsson, N., Steinpórsson, S., and Sigvaldason, G. E. (1985). Iceland Geochemical anomaly: origin, volcanotectonics, chemical fractionation and isotope evolution of the crust. J. Geophys. Res. 90, 10011-10025. doi: 10.1029/ JB090iB12p10011

Paris, R., Guillou, H., Carracedo, J. C., and Perez Torrado, F. J. (2005). Volcanic and morphological evolution of La Gomera (Canary Islands), based on new K-Ar ages and magnetic stratigraphy: implications for ocean island evolution. J. Geol. Soc. London 162, 501-512. doi: 10.1144/0016-764904-055

Parker, D. F., and White, J. C. (2008). Large-scale silicic alkalic magmatism associated with the Buckhorn Caldera, Trans-Pecos Texas, USA: comparison with Pantelleria, Italy. Bull. Volcanol. 70, 403-415. doi: 10.1007/s00445-0070145-2

Parnell-Turner, R., White, N., Henstock, T., Murton, B., Maclennan, J., and Jones, S. M. (2014). A continuous 55-million-year record of transient mantle plume activity beneath Iceland. Nat. Geosci. 7, 914-919. doi: 10.1038/ngeo2281

Peccerillo, A., Barberio, M. R., Yirgu, G., Ayalew, D., Barbieri, M., and Wu, T. W. (2003). Relationships between mafic and peralkaline silicic magmatism in continental rift settings: a petrological, geochemical and isotopic study of the
Gedemsa volcano, central Ethiopian rift. J. Petrol. 44, 2003-2032. doi: 10.1093/ petrology/egg068

Peccerillo, A., Donati, C., Santo, A. P., Orlando, A., Yirgu, G., and Ayalew, D. (2007). Petrogenesis of silicic peralkaline rocks in the Ethiopian rift: geochemical evidence and volcanological implications. J. Afr. Sci. 48, 161-173. doi: 10.1016/j.jafrearsci.2006.06.010

Perlingeiro, G., Vasconcelos, P. M., Knesel, K. M., Thiede, D. S., and Cordani, U. G. (2013). ${ }^{40} \mathrm{Ar} /{ }^{39} \mathrm{Ar}$ geochronology of the Fernando de Noronha Archipelago and implications for the origin of alkaline volcanism in the NE Brazil. J. Volcanol. Geother. Res. 249, 140-154. doi: 10.1016/j.jvolgeores.2012.08.017

Pfaff, K., Krumrei, T., Marks, M., Wenzel, T., Rudolf, T., and Markl, G. (2008). Chemical and physical evolution of the 'lower layered sequence' from the nepheline syenitic Ilímaussaq intrusion, South Greenland: Implications for the origin of magmatic layering in peralkaline felsic liquids. Lithos 106, 280-296. doi: 10.1016/j.lithos.2008.07.018

Pimentel, A. (2006). Domos e Coulées da Ilha Terceira: Contribuição por o Estudo dos Mecanismos de Instalação. M.Sc. thesis, Universidade dos Açores, Ponta Delgada.

Pimentel, A. (2015). Pyroclastic Density Current-Forming Eruptions on Faial and Terceira islands, Azores. Ph.D. thesis, Universidade dos Açores, Ponta Delgada.

Pimentel, A., Pacheco, J., and Self, S. (2015). The $\sim 1000$-years BP explosive eruption of Caldeira Volcano (Faial, Azores): the first stage of incremental caldera formation. Bull. Volcanol. 77:42. doi: 10.1007/s00445-0150930-2

Pires, G. L. C., and Bongiolo, E. M. (2016). The nephelinitic-phonolitic volcanism of the Trindade Island (South Atlantic Ocean): review of the stratigraphy, and inferences on the volcanic styles and sources of nephelinites. J. South Am. Earth Sci. 72, 49-62. doi: 10.1016/j.jsames.2016.07.008

Pires, G. L. C., Bongiolo, E. M., Geraldes, M. C., Renac, C., Santos, A. C., Jourdan, F., et al. (2016). New ${ }^{40} \mathrm{Ar} /{ }^{39} \mathrm{Ar}$ ages and revised ${ }^{40} \mathrm{~K} /{ }^{40} \mathrm{Ar}$ data from nephelinitic-phonolitic volcanic successions of the Trindade Island (South Atlantic Ocean). J. Volcanol. Geother. Res. 327, 531-538. doi: 10.1016/j. jvolgeores.2016.09.020

Pitman, W., and Talwani, M. (1972). Sea floor spreading in the North Atlantic. Geol. Soc. Am. Bull. 83, 619-646. doi: 10.1130/0016-7606(1972)83[619: SSITNA]2.0.CO;2

Plesner, S., Holm, P. M., and Wilson, J. R. (2003). ${ }^{40} \mathrm{Ar}-{ }^{39} \mathrm{Ar}$ geochronology of Santo Antão, Cape Verde Islands. J. Volcanol. Geother. Res. 120, 103-121. doi: 10.1016/S0377-0273(02)00367-0

Pollard, P. J. (1995). A special issue dedicated to the geology of rare metal deposits: geology of rare metal deposits: an introduction an overview. Econ. Geol. 90, 489-494. doi: 10.2113/gsecongeo.90.3.489

Preece, K., Barclay, J., Brown, R., and Mark, D. F. (2016). A 1 million year eruption history of Ascension Island: Insights from stratigraphy and ${ }^{40} \mathrm{Ar} /{ }^{39} \mathrm{Ar}$ dating. Goldschmidt Abstracts 2017:3215.

Preece, K., Mark, D. F., Barclay, J., Cohen, B. E., Chamberlain, K. J., Jowitt, C., et al. (2018). Bridging the gap: ${ }^{40} \mathrm{Ar} /{ }^{39} \mathrm{Ar}$ dating of volcanic eruptions from the Age of Discovery'. Geology. doi: 10.1130/G45415.1

Prestvik, T. (1982). "Trace element geochemistry of volcanic rocks from Bouvetøya, South Atlantic," in Antarctic Geoscience, ed. C. Craddock (Madison, WI: The University of Wisconsin press), 771-774.

Prestvik, T., Goldberg, S., and Goles, G. (1999). Petrogenesis of the volcanic suite of Bouvetøya (Bouvet Island), South Atlantic. Norsk Geologisk Tidsskrift 79, 205-218. doi: 10.1080/002919699433663

Prestvik, T., Goldberg, S., Karlsson, H., and Grönvold, K. (2001). Anomalous strontium and lead isotope signatures in the off-rift Öræfajökull central volcano in south-east Iceland: Evidence for enriched endmember(s) of the Iceland mantle plume? Earth Planet. Sci. Lett. 190, 211-220. doi: 10.1016/S0012821X(01)00390-9

Putirka, K. D. (2008). Thermometers and barometers for volcanic systems. Rev. Mineral. Geochem. 69, 61-120. doi: 10.2138/rmg.2008.69.3

Quin, J. P. (1962). La lindinosite (granite mesocrate à riebeckite) du massif d'Evisa. Bull. Soc. Geol. France 4, 380-383.

Ramalho, R. A. (2011). Building the Cape Verde Islands. Berlin: Springer Science and Business Media. doi: 10.1007/978-3-642-19103-9

Ramalho, R. S., Brum da Silveira, A., Fonseca, P. E., Madeira, J., Cosca, M., Cachão, M., et al. (2015). The emergence of volcanic islands on a slow-moving 
plate: the example of Madeira Island, NE Atlantic. Geochem. Geophys. Geosyst. 16, 522-537. doi: 10.1002/2014GC005657

Ramalho, R. S., Helffrich, G., Madeira, J., Cosca, M., Thomas, C., Quartau, R., et al. (2017). Emergence and evolution of Santa Maria Island (Azores) - The conundrum of uplifted islands revisited. Geol. Soc. Am. Bull. 129, 372-390. doi: 10.1130/B31538.1

Rasmussen, E., Neumann, E.-R., Andersen, T., Sundvoll, B., Fjerdingstad, V., and Stabel, A. (1988). Petrogenetic processes associated with intermediate and silicic magmatism in the Oslo Rift, south-east Norway. Mineral. Mag. 52, 293-307. doi: 10.1180/minmag. 1988.052.366.01

Reagan, M. K., Turner, S., Legg, M., Sims, K. W., and Hards, V. L. (2008). 238Uand 232Th-decay series constraints on the timescales of crystal fractionation to produce the phonolite erupted in 2004 near Tristan da Cunha, South Atlantic Ocean. Geochim. Cosmochim. Acta 72, 4367-4378. doi: 10.1016/j.gca.2008. 06.002

Ren, M., Omenda, P. A., Anthony, E. Y., White, J. C., Macdonald, R., and Bailey, D. K. (2006). Application of the QUILF thermobarometer to the peralkaline trachytes and pantellerites of the Eburru volcanic complex, East African Rift, Kenya. Lithos 91, 109-124. doi: 10.1016/j.lithos.2006.03.011

Renzulli, A., and Santi, P. (2000). Two-stage fractionation history of the alkali basalt-trachyte series of Sete Cidades volcano (São Miguel, Azores). Eur. J. Mineral. 12, 469-494. doi: 10.1127/0935-1221/2000/0012-0469

Ridolf, F., Renzulli, A., Macdonald, R., and Upton, B. G. J. (2006). Peralkaline syenite autoliths from Kilombe volcano, Kenya Rift Valley: evidence for subvolcanic interaction with carbonatitic fluids. Lithos 91, 373-392. doi: 10. 1016/j.lithos.2006.03.026

Ridolfi, F., Santi, P., Renzulli, A., and Upton, B. G. J. (2003). Evolutionary stages of crystallisation of weakly peralkaline syenites: evidence from ejecta in the Plinian deposits of Agua de Pau volcano (São Miguel, Azores Islands). Mineral. Mag. 67, 749-767. doi: 10.1180/0026461036740131

Robertson, A. H. F., and Stillman, C. J. (1979). Late Mesozoic sedimentary rocks of Fuerteventura, Canary Islands: implications for West African continental margin evolution. J. Geol. Soc. 136, 47-60. doi: 10.1144/gsjgs.136.1.0047

Rodriguez-Losada, J. A., and Martinez-Frias, J. (2004). The felsic complex of Vallehermoso Caldera: interior of an ancient volcanic system (La Gomera, Canary Islands). J. Volcanol. Geother. Res. 137, 261-284. doi: 10.1016/j. jvolgeores.2004.05.021

Rogers, N. W., Evans, P. J., Blake, S., Scott, S. C., and Hawkesworth, C. J. (2004). Rates and timescales of fractional crystallization from 238U-230Th-226Ra disequilibria in trachyte lavas from Longonot volcano, Kenya. J. Petrol. 45, 1747-1776. doi: 10.1093/petrology/egh032

Rooney, T. O., Hart, W. K., Hall, C. M., Ayalew, D., Ghiorso, M. S., Hidalgo, P., et al. (2012). Peralkaline magma evolution and the tephra record in the Ethiopian Rift. Contrib. Mineral. Petrol. 164, 407-426. doi: 10.1007/s00410-012-0744-6

Ryabchikov, I. D., and Kogarko, L. N. (1994). Redox equilibria in alkaline lavas from Trindade Island, Brazil. Int. Geol. Rev. 36, 473-483. doi: 10.1080/ 00206819409465472

Sabine, P. A. (1960). The geology of Rockall, north Atlantic. Bull. Geol. Surv. Great Britain 16, 156-178.

Salvi, S., and Williams-Jones, A. E. (2006). Alteration, HFSE mineralisation and hydrocarbon formation in peralkaline igneous systems: insights from the Strange Lake Pluton, Canada. Lithos 91, 19-34. doi: 10.1016/j.lithos.2006.03.040

Scaillet, B., Holtz, F., and Pichavant, M. (1998). Phase equilibrium constraints on the viscosity of silicic magmas 1. Volcanic-plutonic comparison. J. Geophys. Res. 103, 27257-27266. doi: 10.1029/98JB02469

Scaillet, B., and Macdonald, R. (2001). Phase relations of peralkaline silicic magmas and petrogenetic implications. J. Petrol. 42, 825-845. doi: 10.1093/petrology/42. 4.825

Schilling, J. G. (1973). Iceland mantle plume. Nature 246, 141-143. doi: 10.1038/ 246141a0

Schmincke, H.-U. (1969). Ignimbrite sequence on Gran Canaria. Bull. Volcanol. 33, 1199-1219. doi: 10.1007/BF02597716

Schmincke, H.-U. (1973). Magmatic evolution and tectonic regime in the Canary, Madeira, and Azores Island groups. Geol. Soc. Am. Bull. 84, 633-648. doi: 10.1130/0016-7606(1973)84<633:MEATRI >2.0.CO;2

Schmincke, H.-U. (1974). Volcanological aspects of peralkaline silicic welded ash-flow tuffs. Bull. Volcanol. 38, 594-636. doi: 10.1007/BF02596900
Schmincke, H.-U. (1976). "The geology of the Canary Islands," in Biogeography and Ecology in the Canary Islands, ed. G. Kunkel (Berlin: Springer), 67-184. doi: 10.1007/978-94-010-1566-0_4

Schwarz, S., Klügel, A., and Wohlgemuth-Ueberwasser, C. (2004). Melt extraction pathways and stagnation depths beneath the Madeira and Desertas rift zones (NE Atlantic) inferred from barometric studies. Contrib. Mineral. Petrol. 147, 228-240. doi: 10.1007/s00410-004-0556-4

Self, S. (1974). Recent Volcanism on Terceira, Azores. Ph.D. thesis, Imperial College London, London, 236.

Self, S. (1976). The recent volcanology of terceira, azores. J. Geol. Soc. London 132, 645-666. doi: 10.1144/gsjgs.132.6.0645

Serralheiro, A. (1976). A geologia da Ilha de Santiago (Cabo Verde). Bol. Museu Lab. Mineral. Geol. Faculdade Ciênc. 14, 157-369.

Serralheiro, A., Forjaz, V. H., Alves, C. A. M., and Rodrigues, B. (1989). Carta vulcanológica dos Açores, ilha do Faial (1:15000) Sheets 1, 2, 3 \& 4. Ponta Delgada: Centro de Vulcanologia do INIC, Serviço Regional de Proteção Civil dos Açores e Universidade dos Açores.

Shaw, H. R. (1972). Viscosities of magmatic silicate liquids - empirical method of prediction. Am. J. Sci. 272, 870-893. doi: 10.2475/ajs.272.9.870

Siebel, W., Becchio, R., Volker, F., Hansen, M. A. F., Viramonte, J., Trumbull, R., et al. (2000). Trindade and Martin Vaz Islands, South Atlantic: isotopic (Sr, Nd, $\mathrm{Pb}$ ) and trace element constraints on plume-related magmatism. J. South Am. Earth Sci. 13, 79-103. doi: 10.1016/S0895-9811(00)00015-8

Sigmarsson, O., Condomines, M., and Fourcade, S. (1992). A detailed Th, Sr and $\mathrm{O}$ isotope study of Hekla: differentiation processes in an Icelandic volcano. Contrib. Mineral. Petrol. 112, 20-34. doi: 10.1007/BF00310953

Sigmarsson, O., Hémond, C., Condomines, M., Fourcade, S., and Oskarsson, N. (1991). Origin of silicic magma in Iceland revealed by Th isotopes. Geology 19, 621-624. doi: 10.1130/0091-7613(1991)019<0621:OOSMII> 2.3.CO;2

Sigurdsson, H. (1971). Feldspar relations in Icelandic alkalic rhyolites. Mineral. Mag. 38, 503-510. doi: 10.1180/minmag.1971.038.296.13

Sigurdsson, H. (1977). Generation of Icelandic rhyolites by melting of plagiogranites in the oceanic layer. Nature 269, 25-28. doi: 10.1038/269025a0

Sigurdsson, H., and Sparks, R. S. J. (1981). Petrology of rhyolitic and mixed magma ejecta from the 1875 eruption of Askja, Iceland. J. Petrol. 22, 41-84. doi: 10.1093/petrology/22.1.41

Sliwinski, J. T., Bachmann, O., Ellis, B. S., Dávila-Harris, P., Nelson, B. K., and Dufek, J. (2015). Eruption of shallow crystal cumulates during explosive phonolitic eruptions on Tenerife, Canary Islands. J. Petrol. 56, 2173-2194. doi: 10.1093/petrology/egv068

Snyder, D. C., Widom, E., Pietruszka, A. J., and Carlson, R. W. (2004). The role of open-system processes in the development of silicic magma chambers: a chemical and isotopic investigation of the Fogo A trachyte deposit, São Miguel, Azores. J. Petrol. 45, 723-738.

Snyder, D. C., Widom, E., Pietruszka, A. J., Carlson, R. W., and Schmincke, H. U. (2007). Time scales of formation of zoned magma chambers: U-series disequilibria in the Fogo A and $1563 \mathrm{AD}$ trachyte deposits, Sao Miguel, Azores. Chem. Geol. 239, 138-155. doi: 10.1016/j.chemgeo.2007.01.002

Sokolova, E., and Cámara, F. (2017). The seidozerite supergroup of TS-block minerals: nomenclature and classification, with change of the following names: rinkite to rinkite-(Ce), mosandrite to mosandrite-(Ce), hainite to hainite- $(\mathrm{Y})$ and innelite-1T to innelite-1A. Mineral. Mag. 81, 1457-1484. doi: 10.1180/ minmag.2017.081.010

Sørensen, H. (1960). "On the agpaitic rocks," in International Geological Congress, Report of the Twenty-First Session Norden, Part XIII, Proceedings of Section 13, Petrographic Provinces, Igneous and Metamorphic Rocks, Norden, 319-327.

Sørensen, H. (1992). Agpaitic nepheline syenites: a potential source of rare elements. Appl. Geochem. 7, 417-427. doi: 10.1016/0883-2927(92)90003-L

Sørensen, H. (1997). The agpaitic rocks - an overview. Mineral. Mag. 61, 485-498. doi: 10.1180/minmag.1997.061.407.02

Sparks, R. S. J., Sigurdsson, H., and Wilson, L. (1977). Magma mixing: a mechanism for triggering acid explosive eruptions. Nature 267, 315-318. doi: 10.1038/ $267315 \mathrm{a} 0$

Stevenson, R. J., Briggs, R. M., and Hodder, A. P. W. (1993). Emplacement history of a low-viscosity, fountain-fed pantelleritic lava flow. J. Volcanol. Geother. Res. 57, 39-56. doi: 10.1016/0377-0273(93)90030-U 
Storey, M. (1981). Trachytic pyroclastics from Agua de Pau volcano, São Miguel, Azores: evolution of a magma body over 4,000 years. Contrib. Mineral. Petrol. 78, 423-432. doi: 10.1007/BF00375204

Storey, M., Wolff, J. A., Norry, M. J., and Marriner, G. F. (1989). Origin of hybrid lavas from Agua de Pau volcano, São Miguel, Azores. Geol. Soc. London Spec. Publications 42, 161-180. doi: 10.1144/GSL.SP.1989.042.01.11

Streck, M. J. (2014). Evaluation of crystal mush extraction models to explain crystal-poor rhyolites. J. Volcanol. Geother. Res. 284, 79-94. doi: 10.1016/j. jvolgeores.2014.07.005

Stroncik, N. A., Klügel, A., and Hansteen, T. H. (2009). The magmatic plumbing system beneath El Hierro (Canary Islands): contrasts from phenocrysts and naturally quenched basaltic glasses in submarine rocks. Contrib. Mineral. Petrol. 157, 593-607. doi: 10.1007/s00410-008-0354-5

Suh, C. E., Sparks, R. S. J., Fitton, J. G., Ayonghe, S. N., Annen, C., Nana, R., et al. (2003). The 1999 and 2000 eruptions of Mount Cameroon: eruption behaviour and petrochemistry of lava. Bull. Volcanol. 65, 267-283. doi: 10.1007/s00445002-0257-7

Sumner, J. M., and Branney, M. J. (2002). The emplacement history of a remarkable heterogeneous, chemically-zoned, rheomorphic and locally lavalike ignimbrite: 'TL' on Gran Canaria. J. Volcanol. Geother. Res. 115, 109-138. doi: 10.1016/S0377-0273(01)00311-0

Sumner, J. M., and Wolff, J. (2003). Petrogenesis of mixed-magma, high-grade, peralkaline ignimbrite 'TL' (Gran Canaria): diverse styles of mixing in a replenished, zoned magma chamber. J. Volcanol. Geother. Res. 126, 109-126. doi: 10.1016/S0377-0273(03)00121-5

Sun, S., and McDonough, W. F. (1989). "Chemical and isotopic systematics of ocean basins: implications for mantle composition and processes," in Magmatism in the Ocean Basins, Vol. 42, eds A. D. Saunders and M. J. Norry (London: Geological Society of London Special Publication), 313-346.

Sutherland, D. S. (1974). Petrography and mineralogy of the peralkaline silicic rocks. Bull. Volcanol. 38, 518-547. doi: 10.1007/BF02596897

Sæmundsson, K. (1978). Fissure swarms and central volcanoes of the neovolcanic zones of Iceland. Geol. Soc. London Spec. Issue 10, 415-432.

Sæmundsson, K. (1979). Outline of the geology of Iceland. Jökull 29, 7-28.

Thirlwall, M. F., Jenkins, C., Vroon, P. Z., and Mattey, D. P. (1997). Crustal interaction during construction of oceanic islands: $\mathrm{Pb}-\mathrm{Sr}-\mathrm{Nd}-\mathrm{O}$ isotope geochemistry of the shield basalts of Gran Canaria, Canary Islands. Chem. Geol. 135, 233-262. doi: 10.1016/S0009-2541(96)00118-0

Thirlwall, M. F., Singer, B. S., and Marriner, G. F. (2000). 39Ar-40Ar ages and geochemistry of the basaltic shield stage of Tenerife, Canary Islands, Spain. J. Volcanol. Geother. Res. 103, 247-297. doi: 10.1016/S0377-0273(00)00227-4

Thompson, R. N. (1969). Tertiary granites and associated rocks of the Marsco area, Isle of Skye. Quarterly J. Geol. Soc. London 124, 349-385. doi: 10.1144/gsjgs.124. 1.0349

Thompson, R. N., Gibson, S. A., Mitchell, J. G., Dickin, A. P., Leonardos, O. H., Brod, J. A., et al. (1998). Migrating Cretaceous-Eocene magmatism in the Serra do Mar Alkaline Province, SE Brazil: melts from the deflected Trindade mantle plume? J. Petrol. 39, 1493-1526. doi: 10.1093/petroj/39.8.1493

Thompson, R. N., and MacKenzie, W. S. (1967). Feldspar-liquid equilibria in peralkaline acid liquids: an experimental study. Am. J. Sci. 265, 714-734. doi: 10.2475/ajs.265.8.714

Thorarinsson, S. (1981). "Jardeldasvædi á nútíma (Volcanic areas of the Holocene)," in Nattúra Íslands, 2nd Edn, (Reykjavík: Almenna bókafélagid), 81-119.

Thorarinsson, S., and Sæmundsson, K. (1979). Volcanic activity in historical time. Jökull 29, 29-32.

Thordarson, T., and Hoskuldsson, A. (2002). Iceland. Classic Geology in Europe 3. Harpenden: Terra Publishing, 200.

Thordarson, T., and Larsen, G. (2007). Volcanism in Iceland in historical time: volcano types, eruption styles and eruptive history. J. Geodyn. 43, 118-152. doi: $10.1016 /$ j.jog.2006.09.005

Till, C. B., Vazquez, J. A., and Boyce, J. W. (2015). Months between rejuvenation and volcanic eruption at Yellowstone caldera, Wyoming. Geology 43, 695-698. doi: 10.1130/G36862.1

Tornare, E., Pilet, S., and Bussy, F. (2016). Magma differentiation in vertical conduits reealed by the complementary study of plutonic and volcanic rocks from Fuertaventura (Canary Islands). J. Petrol. 57, 2221-2250. doi: 10.1093/ petrology/egx004
Torres, P., Madeira, J., Silva, L., Brum da Silveira, A., Serralheiro, A., and Mota Gomes, A. (1997). "Carta Geológica das erupções históricas da Ilha do Fogo: revisão e actualização," in A Erupção Vulcânica de 1995 na Ilha do Fogo, Cabo Verde. Ministério da Ciencia e da Tecnologia, eds A. Réffega, M. Figueiredo, L. Silva, F. Costa, M. Mendes, P. Torres, et al. (Lisbon: Instituto de Investigação Científica Tropical), 119-132.

Torres, P. C., Silva, L. C., Serralheiro, A., Mendes, M. H., Macedo, J. R., and Gomes, M. (2002). Geologia da Ilha do Sal. Lisbon: Comunicações do Instituto de Investigação Científica Tropical.

Triebold, S., Kronz, A., and Wörner, G. (2006). Anorthite-calibrated backscattered electron profiles, trace elements, and growth textures in feldspars from the Teide-Pico Viejo volcanic complex (Tenerife). J. Volcanol. Geother. Res. 154, 117-130. doi: 10.1016/j.jvolgeores.2005.09.023

Troll, V. R., and Carracedo, J. C. (2016). The geology of the Canary Islands. Amsterdam: Elsevier, 636.

Troll, V. R., Klügel, A., Longpré, M. A., Burchardt, S., Deegan, F. M., Carracedo, J. C., et al. (2012). Floating stones off El Hierro, Canary Islands: xenoliths of preisland sedimentary origin in the early products of the October 2011 eruption. Solid Earth 3, 97-110. doi: 10.5194/se-3-97-2012

Troll, V. R., and Schmincke, H.-U. (2002). Magma mixing and crustal recycling recorded in ternary feldspar from compositionally zoned peralkaline ignimbrite 'A', Gran Canaria, Canary Islands. J. Petrol. 43, 243-270. doi: 10.1093/petrology/ 43.2.243

Trua, T., Deniel, C., and Mazzuoli, R. (1999). Crustal control in the genesis of Plio-Quaternary bimodal magmatism of the Main Ethiopian Rift (MER): geochemical and isotopic ( $\mathrm{Sr}, \mathrm{Nd}, \mathrm{Pb})$ evidence. Chem. Geol. 155, 201-231. doi: 10.1016/S0009-2541(98)00174-0

Turbeville, B. N. (1993). Sidewall differentiation in an alkalic magma chamber: evidence from syenite xenoliths in tuffs of the Latera caldera, Italy. Geol. Mag. 130, 453-470. doi: 10.1017/S0016756800020537

Turner, J. S., and Campbell, I. H. (1986). Convection and mixing in magma chambers. Earth Sci. Rev. 23, 255-352. doi: 10.1016/0012-8252(86) 90015-2

Turner, S., Kokfelt, T., Hoernle, K., Johansen, T. S., Hauff, F., Lundstrom, C., et al. (2017). Contrasting magmatic cannibalism forms evolved phonolitic magmas in the Canary Islands. Geology 45, 147-150. doi: 10.1130/ G38566.1

Ulbrich, M. N. C. (1993). Petrography of alkaline volcanic-subvolcanic rocks from the Brazilian Fernando de Noronha archipelago, southern Atlantic Ocean. Bull. Instit. Geosci. Univ. São Paulo 24, 77-94.

Venezky, D. Y., and Rutherford, M. J. (1999). Petrology and Fe-Ti oxide reequilibration of the 1991 Mount Unzen mixed magma. J. Volcanol. Geother. Res. 89, 213-230. doi: 10.1016/S0377-0273(98)00133-4

Verwoerd, W. J. (1972). Islands on the mid-ocean ridge between Africa and Antarctica. Trans. Am. Geophys. Union 53, 168-170.

Verwoerd, W. J., Erlank, A. J., and Kable, E. J. D. (1976). "Geology and geochemistry of Bouvet Island," in Andean and Antarctic Volcanology Problems, ed. O. Gonzales Ferran (Naples: IAVCEI), 203-237.

Vink, G. E. (1984). A hotspot model for Iceland and the Voring Plateau. J. Geophys. Res. 89, 9949-9959. doi: 10.1029/JB089iB12p09949

Vogt, P. R., and Jung, W. Y. (2004). The Terceira Rift as hyper-slow, hotspotdominated oblique speeding axis: a comparison with other slow-spreading plate boundaries. Earth Planet. Sci. Lett. 218, 77-90. doi: 10.1016/S0012-821X(03) 00627-7

Vona, A., Romano, C., Dingwell, D. B., and Giordano, D. (2011). The rheology of crystal-bearing basaltic magmas from Stromboli and Etna. Geochim. Cosmochim. Acta 75, 3214-3236. doi: 10.1016/j.gca.2011.03.031

Walker, G. P. L. (1959). Geology of the Reydarfjördur area, eastern Iceland. Quarterly J. Geol. Soc. London 68, 515-528.

Walker, G. P. L. (1963). The Breiddalur central volcano, eastern Iceland. Quarterly J. Geol. Soc. London 119, 29-63. doi: 10.1144/gsigs.119.1.0029

Walker, G. P. L. (1966). Acid volcanic rocks in Iceland. Bull. Voclanol. 29, 376-402. doi: $10.1007 / \mathrm{BF} 02597164$

Watkins, N. D., and Abdel-Monem, A. (1971). Detection of the Gilsa geomagnetic polarity event on the island of Madeira. Geol. Soc. Am. Bull. 82, 191-198. doi: 10.1130/0016-7606(1971)82[191:DOTGGP]2.0.CO;2

Watkins, N. D., and Walker, G. P. L. (1977). Magnetostratigraphy of EasternIceland. Am. J. Sci. 277, 513-584. doi: 10.2475/ajs.277.5.513 
Weaver, B., Kar, A., Davidson, J., and Collucci, M. (1996). Geochemical characteristics of volcanic rocks from Ascension Island, South Atlantic Ocean. Geothermics 25, 449-470. doi: 10.1016/0375-6505(96)00014-4

Weaver, B. L. (1990). Geochemistry of highly-undersaturated ocean island basalt suites from the Southern Atlantic Ocean: Fernando de Noronha and Trindade islands. Contrib. Mineral. Petrol. 105, 502-515. doi: 10.1007/BF00302491

Webster, J. D., and Rebbert, C. R. (2001). The geochemical signature of fluidsaturated magma determined from silicate melt inclusions in Ascension Island granite xenoliths. Geochim. Cosmochim. Acta 65, 123-136. doi: 10.1016/S00167037(00)00515-9

Weidenorfer, D., Schmidt, M. W., and Mattsson, H. B. (2016). Fractional crystallisation of Si-undersaturated alkaline magmas leading to unmixing of carbonatites on Brava Island (Cape Verde) and a general model of carbonatite genesis in alkaline magma suites. Contrib. Mineral. Petrol. 171:43. doi: 10.1007/ s00410-016-1249-5

Weis, D., Demaiffe, D., Cauet, S., and Javoy, M. (1987). Sr, Nd, O and H isotopic ratios in Ascension Island lavas and plutonic inclusions; cogenetic origin. Earth Planet. Sci. Lett. 82, 255-268. doi: 10.1016/0012-821X(87) 90200-7

Weit, A., Trumbull, R. B., Keiding, J. K., Geissler, W. H., Gibson, S. A., and Veksler, I. V. (2017). The magmatic system beneath the Tristan da Cunha Island: insights from thermobarometry, melting models and geophysics. Tectonophysics 716, 64-76. doi: 10.1016/j.tecto.2016.08.010

White, J. C., Ren, M., and Parker, D. F. (2005). Variation in mineralogy, temperature, and oxygen fugacity in a suite of strongly peralkaline lavas and tuffs, Pantelleria, Italy. Can. Mineral. 43, 1331-1347. doi: 10.2113/gscanmin.43. 4.1331

White, R. S., Brown, J. W., and Smallwood, J. R. (1995). The temperature of the Iceland plume and origin of outward-propagating V-shaped ridges. J. Geol. Soc. London 152, 1039-1045. doi: 10.1144/GSL.JGS.1995.152.01.26

White, W. M. (2010). Oceanic island basalts and mantle plumes: the geochemical perspective. Annu. Rev. Earth Planet. Sci. 38, 133-160. doi: 10.1146/annurevearth-040809-152450

White, W. M., Tapia, M. D. M., and Schilling, J.-G. (1979). The petrology and geochemistry of the Azores islands. Contrib. Mineral. Petrol. 69, 201-213. doi: 10.1007/BF00372322

Whittington, A. G., Richet, P., Linard, Y., and Holtz, F. (2001). The viscosity of hydrous phonolites and trachytes. Chem. Geol. 174, 209-223. doi: 10.1016/ S0009-2541(00)00317-X

Widom, E., Gill, J. B., and Schmincke, H.-U. (1993). Syenite nodules as a long-term record of magmatic activity in Agua de Pau, São Miguel, Azores. J. Petrol. 34, 929-953. doi: 10.1093/petrology/34.5.929

Widom, E., Hoernle, K. A., Shirey, S. B., and Schmincke, H.-U. (1999). Os isotope systematics in the Canary Islands and Madeira: lithospheric contamination and mantle plume signatures. J. Petrol. 40, 279-296. doi: 10.1093/petroj/40.2.279

Widom, E., Schmincke, H.-U., and Gill, J. B. (1992). Processes and timescales in the evolution of a chemically zoned trachyte: Fogo A, São Miguel, Azores. Contrib. Mineral. Petrol. 111, 311-328. doi: 10.1007/BF00311194

Wiesmaier, S., Deegan, F. M., Troll, V. R., Carracedo, J. C., Chadwick, J. P., and Chew, D. M. (2011). Magma mixing in the 1100 AD Montaña Reventada composite lava flow, Tenerife, Canary Islands: interaction between rift zone and central volcano plumbing systems. Contrib. Mineral. Petrol. 162, 651-669. doi: 10.1007/s00410-010-0596-X

Wiesmaier, S., Troll, V. R., Wolff, J. A., and Carracedo, J. C. (2013). Opensystem processes in the differentiation of mafic magma in the Teide-Pico Viejo succession, Tenerife. J. Geol. Soc. London 170, 557-570. doi: 10.1144/jgs 2012-016

Wimmenauer, W. (1974). "Chapter 4.4: the alkaline province of central Europe and France," in The Alkaline Rocks, ed. H. Sørensen (London: Wiley and Sons), 238-271.

Wolfe, C. J., Bjarnason, I. T., Van Decar, J. C., and Soloman, S. C. (1997). Seismic structure of the Iceland mantle plume. Nature 385, 245-247. doi: 10.1038/ $385245 \mathrm{a} 0$
Wolff, J. A. (1985). Zonation, mixing and eruption of silica-undersaturated alkaline magma: a case study from Tenerife, Canary Islands. Geol. Mag. 122, 623-640. doi: $10.1017 /$ S0016756800032039

Wolff, J. A. (1987). Crystallisation of nepheline syenite in a subvolcanic magma system: Tenerife, Canary Islands. . Lithos 20, 207-223. doi: 10.1016/00244937(87)90009-0

Wolff, J. A. (2017). On the syenite-trachyte problem. Geology 45, 1067-1070. doi: $10.1130 / \mathrm{G} 39415.1$

Wolff, J. A., Ellis, B. S., Ramos, F. C., Starkel, W. A., Boroughs, S., Olin, P. H., et al. (2015). Remelting of cumulates as a process for producing chemical zoning in silicic tuffs: a comparison of cool, wet and hot, dry rhyolitic magma systems. Lithos 23, 275-286. doi: 10.1016/j.lithos.2015.09.002

Wolff, J. A., Grandy, J. S., and Larson, P. B. (2000). Interaction of mantle-derived magma with island crust? Trace element and oxygen isotope data from the Diego Hernandez Formation, Las Cañadas, Tenerife. J. Volcanol. Geother. Res. 103, 343-366. doi: 10.1016/S0377-0273(00)00230-4

Wolff, J. A., and Storey, M. (1983). The volatile component of some pumiceforming alkaline magmas from the Azores and Canary Islands. Contrib. Mineral. Petrol. 82, 66-74. doi: 10.1007/BF00371176

Wolff, J. A., and Storey, M. (1984). Zoning in highly alkaline magma bodies. Geol. Mag. 121, 563-575. doi: 10.1017/S0016756800030715

Wolff, J. A., Wörner, G., and Blake, S. (1990). Gradients in physical parameters in zoned felsic magma bodies: implications for evolution and eruptive withdrawal. J. Volcanol. Geother. Res. 43, 37-55. doi: 10.1016/0377-0273(90) 90043-F

Wyllie, P. J., and Tuttle, O. F. (1961). Experimental investigation of silicate systems containing two volatile components. Part II. The effects of NH3 and HF in addition to water on the melting temperatures of granite and albite. Am. J. Sci. 259, 128-143. doi: 10.2475/ajs.259.2.128

Ye, S., Canales, J. P., Rihm, R., Dañobeita, J. J., and Gallart, J. (1999). A crustal transect through the northern and northeastern part of the volcanic edifice of Gran Canaria, Canary Islands. Geodynamics 28, 3-26. doi: 10.1016/S02643707(98)00028-3

Yokoyama, T., Aka, F. T., Kusakabe, M., and Nakamura, E. (2007). Plumelithosphere interaction beneath Mt. Cameroon volcano, West Africa: constraints from $238 \mathrm{U}-230 \mathrm{Th}-226 \mathrm{Ra}$ and $\mathrm{Sr}-\mathrm{Nd}-\mathrm{Pb}$ isotopes systematics. Geochim. Cosmochim. Acta 71, 1835-1854. doi: 10.1016/j.gca.2007.01.010

Zanon, V. (2015). "The magmatism of the Azores islands," in Volcanic Geology of São Miguel Island (Azores Archipelago), Vol. 44, eds J. L. Gaspar, J. E. Guest, A. M. Duncan, F. J. A. S. Barriga, and D. K. Chester (London: Geological Society of London Memoirs), 51-64.

Zanon, V., and Frezzotti, M. L. (2013). Magma storage and ascent conditions beneath Pico and Faial islands (Azores archipelago): a study on fluid inclusions. Geochem. Geophys. Geosyst. 14, 3494-3514. doi: 10.1002/ggge.20221

Zanon, V., Kueppers, U., Pacheco, J. M., and Cruz, I. (2013). Volcanism from fissure zones and the Caldeira central volcano of Faial Island, Azores archipelago: geochemical processes in multiple feeding systems. Geol. Mag. 150, 536-555. doi: 10.1017/S0016756812000702

Zielinski, R. A., and Frey, F. A. (1970). Gough Island: evaluation of a fractional crystallisation model. Contrib. Mineral. Petrol. 29, 242-254. doi: 10.1007/ BF00373308

Conflict of Interest Statement: The authors declare that the research was conducted in the absence of any commercial or financial relationships that could be construed as a potential conflict of interest.

Copyright (c) 2018 Jeffery and Gertisser. This is an open-access article distributed under the terms of the Creative Commons Attribution License (CC BY). The use, distribution or reproduction in other forums is permitted, provided the original author(s) and the copyright owner(s) are credited and that the original publication in this journal is cited, in accordance with accepted academic practice. No use, distribution or reproduction is permitted which does not comply with these terms. 